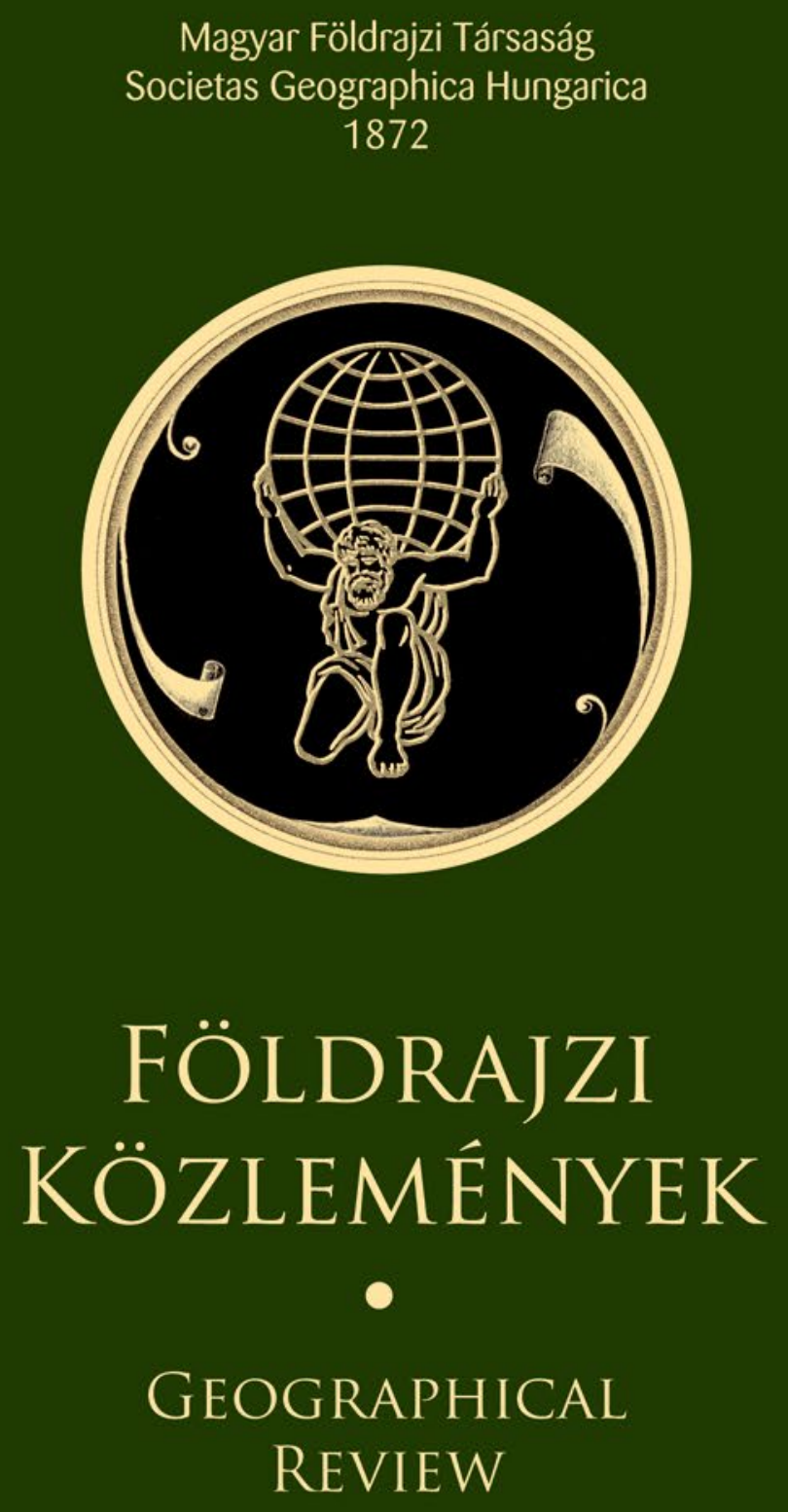




\section{FÖLDRAJZI KÖZLEMÉNYEK}

\section{A Magyar Földrajzi Társaság tudományos folyóirata}

Geographical Review $•$ Geographische Mitteilungen

Bulletin Géographique • Bollettino Geografico • Географические Сообщения

Főszerkesztő / Editor-in-Chief

DÁVID LÓRÁNT DÉNES

Főszerkesztő helyettesek / Deputy Editors-in-Chief

EgEDy TAMÁs (felelôs szerkesztő / Managing editor), BOTTLIK ZsOLT

\section{Szerkesztők / Editors}

HoRvÁth GeRgely, PAPP SÁndOR, Jeney László (olvasószerkesztő / Proofreader)

CSAPÓ JÁNOS (külkapcsolati menedzser / Manager for internationalisation)

Szerkesztőbizottság / Editorial Board

Veit Bachmann (DE), Benedek József (RO), Dombay István (RO), Fábián Szabolcs, Fodor Gyula (UA), GyóRi Róbert, Ionel Haidu (FR), Illés SÁndor, SteVen Jobbitt (CA),

Kozma Gábor, Lóczy Dénes, Peter Lugosi (UK), Mészáros Minucsér (RS), Mucsi LásZló, SZABó GYörgy, TimCSÁK GÉZA (SK), Tímár Judit, Ladislav TolmáČ (SK),

THOMAS M. WILSON (US, IE)

Tudományos Tanácsadó Testület / Scientific Advisory Board

Alexandr Artemyev (KZ), Mariusz Barczak (PL), Barta Györgyi,

Beluszky PÁl, JÜrgen BReuste (AT), Bujdosó ZolTáN,

Centeri Csaba, Csorba Péter, Dövényi Zoltán, FrisnYák SÁndor,

Grażyna FurgaŁa-Selezniow (PL), Gábris Gyula, Gál Zoltán,

György Ottilia (RO), Hufnágel Levente, Dorina Camelia Ilieş (RO),

Kerény AtTila, Blaž Komac (SI), JoAnna KosmaczewSKa (PL),

Kovács Katalin, Kocsis Károly, Kovács Zoltán, Mari László, Mezősi Gábor,

Michalkó Gábor, Ladislav Mura (SK), Pajtókné Tari Ilona, Pap Norbert,

Papp-Váry Árpád, Maria Paradiso (IT), Penksza Károly,

Szilárd Lehel Poszet (RO), Probáld Ferenc, Anton Van Rompaey (BE),

Mihaela Sima (RO), Parikshat Singh Manhas (IN),

SZabó József, SZabó Szilárd, SzIlassi Péter, Tóth GéZa, Tardy János, VARAJTI KÁROLY, MAREK WiĘCKOWSKI (PL)

A Földrajzi Közleményeket az alábbi adatbázisok indexelik:

Földrajzi Közlemények is abstracted/indexed in: EBSCO Information Services, Ulrich's Periodicals Directory, Index Copernicus International, Crossref.

Szerkesztőség: 1112 Budapest, Budaörsi út 45. Telefon, fax: (06-1) 309-2683

E-mail: kozlemenyek@foldrajzitarsasag.hu. Honlap: www.foldrajzitarsasag.hu

Az MTA X. Földtudományok Osztályán kiemelt státuszba sorolt folyóirat. 


\title{
NAGYVÁROSOK A COVID-19 VÍRUSJÁRVÁNY IDEJÉN
}

\author{
SZIRMAI VIKTÓRIA \\ METROPOLISES AT THE TIME OF THE COVID-19 PANDEMIC
}

\begin{abstract}
Nowadays, metropolitan areas are especially affected by the negative economic and social consequences of the COVID-19 pandemic. Everyday life and the urban landscape have also changed in these areas significantly. Because of the current urban and social features, several scientific studies have started to profoundly dispute the positive evaluation of urban settlements. In addition to revealing the real responsibility of metropolises, and their specificities, in the spread of the virus, this paper intends to analyse the virus-related issues in four dimensions: firstly, it presents the different kinds of impact of COVID-19 in the Western and Eastern types of large cities or metropolises. Secondly, it shows how the virus spread from city to city in its (first) emergence period. In addition, the study deals with the determining factors, especially the sociological reasons for the appearance and the development of COVID-19 in large cities. Besides this, the paper hypothetically deals with the possible negative spatial structural consequences in urban areas, so that the metropolises will be able to prepare for the mitigation of the current and future pandemics. Finally, possible solutions for the protection of metropolises will be listed.
\end{abstract}

Keywords: metropolises, social issues, new spatial-social structure, mitigation of pandemic

\section{Bevezetés: a nagyvárosok jövôje}

Jogos feltételezés, hogy a 2019-es évek végén kirobbant, majd a 2020-as évek elejétől rohamosan terjedő, a világ nagyvárosait, globális városait különösképpen súlyosan érintő COVID-19 vírus világjárvány hatásai újraírják a mai nagyvárosok, a globális világvárosok korábbi értékeléseit, illetve megkérdőjelezik a nagyvárosokkal foglalkozó szakirodalmak alapvetôen nagyváros párti beállítottságait. A COVID-19 világjárvány és annak kedvezôtlen egészségügyi következményei, a vírusfertőzöttségből fakadó, tömeges megbetegedések elsősorban nagyvárosi környezetben jelentek meg és onnan szóródtak szét más települések felé és okoztak különböző gazdasági és társadalmi problémákat.

A kialakult kedvezőtlen jelenségek miatt a nagyvárosok jövőjével kapcsolatban viták alakultak ki: sokan úgy vélik, hogy nemcsak a globális városok, a nagyvárosok, hanem az egész globalizált élet meg fog változni. Mások azonban úgy gondolják, hogy a járvány lezajlását követően visszaáll minden a régi kerékvágásba.

Ez a kétféle nézet már a vírusjárványt megelőzően is megtalálható volt a nagyvárosokkal foglalkozók körében. RICHARD FLORIDA amerikai urbanista a 2017-ben megjelent „The New Urban Crisis" (A városok új válsága) címú munkájában hasonlóan két eltérő nézetet valló csoportot különít el (FLORIDA, R. 2017, 3 p.): az egyiket, akiknek a tagjai a városok előnyeit hirdetik, optimistáknak nevezi, (például GLAESER), a másikat, akik a nagyvárosi társadalmi problémákat emelik ki, pesszimistáknak hívja (például HARVEY, DAVIS). A véleménye szerint mind a két nézetnek igaza van, ő maga is ezt a komplexebb felfogást képviseli. A neves amerikai szociológus, közgazdász tudós SASKIA SASSEN globális városról készített munkája, a Global City (SASSEN, S.1991), vagy MoLLENKOPF és CASTELls Dual City múve is (MollenKopf, J.H.-CASTELLS, M. 1991) és még sokan mások is ide sorolhatóak. Ebbe a felfogásba helyezem el a saját munkáimat is (SZIRMAI V. 2009, 2011, 2019). 
A mai járvány kitörését követően azonban, mintha a korábbi arányok felborulni látszanának, a kedvező hatásokat a kedvezőtlen következmények elnyomják, miközben a vírus járvány új problémákat is okoz. Ezekre a problémákra megoldásokat kell találni. Nem mindegy, hogy milyen lesz a nagyvárosok jövője, hiszen a világ népességének ma közel 50\%-a, az európai népesség 74\% -a városokban, városi térségekben él, s ez az arány fokozatosan növekszik. Az előrejelzések szerint 2025-ben a világ népességének közel 62\%-a városlakó lesz. 2050-re a világ népességének 68\%-a városokban lakik majd (KovÁcs Z. 2017).

Igazából nem tudjuk, mi történik a járvánnyal sújtott mai nagyvárosokban. A rendelkezésre álló adatok főként a gazdaság állapotára, annak visszaesésére, a munkanélküliségre vonatkoznak. A WHO illetve a járvánnyal érintett különböző országok, azok kormányai, járványügyi és egyéb kutató intézetek alapvetôen epidemiológiai adatokat közölnek, ezekből a fertőzöttségi esetek, a kórházakban kezeltek, a lélegeztető gépekre helyezettek, a meghaltak száma, továbbá az elvégzett tesztszámok, illetve a gyógyultak adatai kerülnek a nyilvánosság elé. Ezen kívül egyes demográfiai információk (kor, nem) illetve korábbi súlyosabb betegségek derülnek még ki, részben globális szinten, részben az érintett országokra, nagyobb térségekre, megyékre jellemző megoszlásokban. Adatokat találni (például a kelet és a közép-európai országok esetében) a pandémia politikai hatásairól is ${ }^{1}$.

A COVID-19 társadalmi következményeiről, a járvánnyal érintettekről keveset vagy szinte semmit sem tudunk. Sajnálatos módon nagyon kevés a közölt adat arról is, hogy kik, milyen társadalmi helyzetben lévook a mai vírusjárvány által érintett emberek, mi az iskolai végzettségük, a foglalkozásuk, a jövedelmi helyzetük, hol van a lakóhelyük. Ilyen típusú információkat, adatokat, kutatási jelentéseket, publikációkat csak néhány nyugat-európai nagyváros, illetve amerikai nagyváros esetében találtam.

Véleményem szerint az ilyen típusú információk nagyon fontosak lennének, hiszen jogos feltételezés, hogy a társadalmi helyzet, az abból is következő életformák, az egészséghez való viszony sok szempontból befolyásolhatják mind a vírus terjedését, mind pedig a védekezést, a védekezési protokoll betartását is. Ezért ebben a tanulmányban különös figyelmet fordítottam a COVID-19 vírus hatásaival érintettek társadalmi helyzetének a megismerésére.

A tanulmányban mindenekelőtt a nyugat-európai, az amerikai, illetve a kelet- és közép-európai nagyvárosokra jellemző általános helyzetképet vázolom fel, a vírusválság nagyvárosi jeleiről, a gazdasági, a társadalmi hatásokról, a városképek megváltozásairól, a szociális kapcsolatokról. Ezt követően a COVID-19 vírus nagyvárosi terjedésének kezdeti időszakát mutatom be, a nyugat-európai és az amerikai nagyvárosok, illetve (a rendelkezésre álló adatok függvényében) a kelet- és a közép-európai térség, a V4 fővárosok, közte Budapest példáin. Ezt követően elemzem a COVID-19 járvány lehetséges nagyvárosi jelleggel összefüggő okait, részben a szakirodalmi leírások, internetes források, részben a tapasztalati tények, illetve ahol voltak, kutatási eredmények alapján. Itt kerül sor a szociológiai meghatározottságok feltérképezésére is. A következő résztéma azoknak a hipotéziseknek ad teret, amelyekben a COVID-19 járványt követően kialakuló nagyvárosi térbeli társadalmi szerkezet lehetséges trendjeit vázolom, majd végül néhány megoldási lehetőséget vetek fel.

\section{A vírusválság nagyvárosi jelei}

Valószínúleg reális feltételezés, hogy a COVID-19 vírus világjárvány hatásai a mai nagyvárosokról kialakult képet módosítani fogják. Előfordulhat, hogy a nagyvárosi létformát elutasító vélemények többségbe kerülnek majd. Részben azért, mert a mostani 
világjárvány elsősorban nagyvárosi környezetben jelent meg: kórházakban, idősotthonokban, egyházi és szociális valamint oktatási intézményekben, sporteseményeket követôen, vagy a börtönökben. De azért is, mert a nagyvárosokat sújtó világjárvány kedvezőtlenül befolyásolta a globális gazdaság múködését, de a mindennapi életet is.

A globális világot átfogó gazdasági, társadalmi, kereskedelmi kapcsolati hálók megszakadtak, a globális szintú áru- és a teherszállítás, a légi és a vonat, valamint a gépkocsi közlekedés megállt, vagy visszaesett. A nemzetközi túrizmus leállt, a mindennapi élethez feltétlenül szükséges teherszállító repülőgépek mozgásain kívül a repülőterek leszállópályái elcsendesedtek. Történt mindez a vírusveszély megfékezésére, az áruk és az emberek szabad mozgását tiltó intézkedések, országokra és régiókra kiterjedő határzárok miatt. Ezek az intézkedések a globális pénzügyi szolgáltatások áramlását, de azt is akadályozták, hogy a termékek eljussanak a fogyasztókhoz. Továbbá akadályokat állítottak a termelő szférából a pénzgazdaságba való tőke transzferek elé, valamint hátráltatták a különböző szolgáltatások, az információk, a munkaerô szabad áramlását és az ún. ellátási láncok múködését is.

A tények szerint a nagyvárosok (legalábbis átmenetileg) nem képesek úgy viselkedni, mint a globális gazdasági fejlődés csomópontjai, irányító központjai. A nagyvárosokban koncentrálódó transznacionális és a multinacionális vállalatok központjai, regionális intézmények, pénzintézeti centrumok, könyvelés, tanácsadás, bank és a pénzügyek közötti mozgásokat biztosító cégek, valamint a biztosítási, illetve a jogi ügyek képviselői a gazdasági krízis, a globális világpiac múködési zavarai eredményeként vagy teljesen, vagy részben leállnak.

Az alkalmazottak otthoni munkára kényszerültek, ott ahol a cégek ezt meg tudták, vagy meg tudják engedni maguknak. De sokan elküldték (elküldik) az alkalmazottakat, vagy (jobb esetben) csökkentették a munkaidejüket. A nagyvárosokban dolgozók az országos átlagokhoz képest is magasabb százalékban vesztették el a munkájukat, vagy a bérük bizonyos részét (ha azt a központi kormányok nem akarták, nem tudták pótolni).

A COVID-19 járvány miatt különösen nehéz helyzetbe kerültek az informális gazdaságban dolgozó városlakók, ahol a legtöbb munkahely alacsonyan fizetett és távolról nem végezhető el. A World Economic Forum szerint míg a fóiskolai végzettségúek 47\%-a távolról dolgozhatott az Egyesült Államokban 2020. júliusában, az érettségivel nem rendelkezők csak 4\%-nak volt erre módja (World Economic Forum 2020). A nyolcmilliós Dakkában, Banglades fôvárosában a munkavállalók több mint 80\%-a az informális szektortól függ. Ezen dolgozók napi bérének $62 \%$-a június hónapjában gyakorlatilag eltûnt ${ }^{2}$.

A problematikus hatások egy külön csoportját mutatják a globális gazdaság múködését biztosító és jelző irodaházak, azok kiüresedése. Minden globális városban és nagyvárosban ott vannak a többnyire hatalmas, több szintes, üveg és beton épületek: a nagyvárosi központokban, a központi üzleti negyedekben, de a külső városi gyúrűkben is. Különböző építési korszakokat és eltérő színvonalú szolgáltatásokat, munkahelyeket és tárgyalótermeket kínálnak, emellett az ingatlan városban elfoglalt helyéből fakadó területi presztízst is nyújtanak a különböző fogyasztási igényű és eltérő fizetőképes bérlőknek, vásárlóknak. Ezek az irodaházak a „,home office”, vagyis az otthoni munkavégzésre átállás miatt átmenetileg vagy véglegesen feleslegessé váltak, kiüresedtek, vagy üresebbé váltak. Az ingatlanadók, az irodaházak bérleti díjainak és egyéb bevételi források drámai csökkenése súlyosan veszélyezteti az önkormányzatok pénzügyi lehetőségeit, az alapvető szolgáltatások biztosítását.

A városkép is kedvezőtlenül alakult. A 2019-es évi és a 2020-as év eleji járvány eseményeit követôen a nagyvárosok, de a talán a legfeltűnőbben a belvárosok utcái, terei szinte teljesen kiürültek, a nemzetközi túrizmus leállása, a részleges vagy a teljes körû kijárási tilalmak, a mindennapi élet ritmusának, tartalmának a változásai miatt. 
Ezzel kapcsolatban van egy személyes élményem. A vírus ügyről közvetítő televízió adások segítségével már többször is láttam teljesen vagy részlegesen kiürült európai belvárosokat: Bécs, Párizs, de London, vagy New York belvárosai ugyanúgy kiürültek, mint Budapest belső negyede azon a 2020 nyár eleji napon (az ún. elsô hullám vége felé), amikor a családommal ebédelni indultunk. Egy budapesti hotel, Dunára néző teraszát választottuk ki, s bár az étterem (akkor még) nyitva volt és az ebéd és a kiszolgálás is kitűnő volt, mi voltunk az egyedüli vendégek. De ennél is nagyobb sokkot okoztak a kiüresedett belvárosi utcák és terek: sehol egy nézelődő turista, sehol egy kutyát sétáltató, sehol egy gyerekes család, teljes volt a csend, vasárnap révén hivatalnokok sem lehettek az utcákon. $\mathrm{S}$ a munkájukat féltő pincérek félelme a szomorú hangulatot még tovább tetézte.

Pedig ez a történet még csak a nyitány volt, később, fóként a második hullám idején már nem csupán kiüresedtek, hanem be is zártak az éttermek, a bárok, a bisztrók, a szórakozó helyek, a különböző fesztiválok, a kisebb vásárok, közte később a karácsonyi vásár is tiltó listákra kerültek. A mozik, színházak, koncerttermek szintén kényszerúen bezártak, az oktatás vagy szünetelt, vagy online formára váltott.

A járványügyi nézőpontból jogos intézkedéseket globális munkanélküliség követte: a piaci, de az állami szektorokban dogozó alkalmazottak, a múvészek, zenészek, színészek, kisvállalkozók, a szállodaiparban, a vendéglátásban foglalkoztattak nehéz, sokszor elviselhetlen élethelyzetekbe kerültek. A különböző szolgáltatásokat is elérték a korlátozások, fodrászok, kozmetikusok, fitnesztermek zártak be. A bevásárlóközpontok, a kisebb boltok ugyan többnyire nyitva maradtak, de sokkal kihaltabbakká váltak, mint amilyenek korábban voltak, sok dolgozót onnan is elküldtek. A kialakult helyzet azonban a különböző webáruházaknak előnyös volt, sokan (főként városiak, középosztálybeleik) vásároltak interneten keresztül legkülönbözőbb dolgokat: élelmiszert, ruhát, könyveket, háztartási gépeket. Az ételkiszállítás mellett döntő éttermek is előnyöket élveztek a bezárt éttermekhez képest, sokan rendeltek így ételt. Ez pedig nem kevés, munkáját elvesztett, a városi forgalomban jól boldoguló, biciklizni tudó fiatalnak hozott munkát és valamilyen szintű megélhetést.

Sok tevékenységet a virtuális tér, a digitalizáció mentett meg: a legkülönbözőbb tudományos rendezvények, nemzeti és nemzetközi konferenciák, könyvbemutatók, egyes színházi előadások, filmbemutatók, múzeumi tárlatok online formát kaptak és kapnak.

Lényeges különbségeket tapasztalni az egyes országok között, de a kormányzati döntések szigora vagy engedékenysége szerint is. Az emberi viselkedés kulturális eltérései szintén eltéréseket okoztak: a kollektívabb, közösségibb, kapcsolatgazdagabb, élénkebb családi, rokonsági életre épülő, nyitottabb, egyben befogadóbb társadalmak sérülékenyebbeknek tûnnek a vírusfertőzésre, mint az individuálisabb, befelé forduló életvitelt folytató országok társadalmai. A járvány két hulláma között is látni lehet eltéréseket. Az első hullámban (például Magyarországon) sokkal fegyelmezettebbek voltak az emberek, nyilván jobban is féltek, a második periódusban már többet engedtek meg maguknak, a 2020-as karácsony előtti vásárlások idején (sajnos, de azért érthető módon) hatalmas tömegekről számoltak be a televíziós músorok.

A következő súlyos gondot a szociológiai hatások adják. A „maradj otthon mozgalom" eredményeként is, a járványtól való félelem és a hatósági tiltások, a kényszerú cégleállások, a különböző intézményi bezárások miatt a munkavállalók, a diákok, előbb az egyetemisták, később a középiskolások is otthon maradtak. Mindez a szemtől szembeni kapcsolatok torzulásait adta, amit különösképpen súlyosbított, hogy sem a családok, sem a barátok, sem a munkatársak nem találkoztak, a számítógép különböző programjai adták (és adják) a találkozások virtuális felületeit, de azt is csak azoknak, akiknek megvolt (megvan) az ahhoz szükséges technikája és technikai tudása. A virtuális kapcsolatok nem tudják pótolni az élő, az összetartozást is kifejezni képes családi életet és a baráti talál- 
kozásokat. Amit csak tetézett az üres utcák hangulataiból adódó magány és izoláltság és az egyénekre leselkedő életveszély érzése. És nem szabad kihagyni a felsorolásból azt az elképzelhetlen rettenetet, amit az idősotthonok lakói átélnek, átéltek, vagy amit a kórházban lévő betegek, vagy az élettől magányosan elköszönő emberek érezhettek, érezhetnek.

A másik szintén komoly társadalmi problémakör a járványveszély és annak gazdasági következményeinek alakulását tükröző konfliktusok. Ellentmondásokat érzékelni a már fertőzöttek és a veszélyeztetettek, a karanténba zártak és azokat kívülrôl figyelők, a járvány különböző hullámaiban eltérően érintett korcsoportok, az idősek, a fiatalok, a nagyobb és a kisebb városiak, a gazdagabbak és a szegényebbek, a romák és a nem romák, a vakcinával beoltottak és azt (különböző okoknál fogva) nem vállalók, az elutasítók, vagy éppen a vakcinára még csak várók és a már beoltottak között. Az országok közötti egyenlőtlenségeket és annak hangoztatását sem szabad elfejteni. Ahogy a pártok között zajló rivalizációt sem, a folyamatos vitát arról, hogy melyik párt, vagy melyik ország kormánya, vagy éppen az EU mit tett vagy mit nem tett a védelem érdekében.

A legnagyobb gondot azonban a különböző veszélyek kumulatív rendszerei adják: mégpedig az, hogy a világjárvány összekapcsolódik a globális gazdasági válsággal, a munkanélküliség és a szegénység növekedésével, a társadalmi és térbeli polarizációval, valamint a globális városok kiszámíthatatlan sorsával.

Mindeközben érzékelhetők reményt keltő dolgok is: az Európai Unió, a WHO, a különböző kormányok, a nagy civil szervezetek illetve egyházak segítsége a bajba kerülteknek, az egyéni jótékonyság erősödése, de legfőképpen a kifejlesztett vakcinák és gyógyszerek szaporodó száma.

\section{A kezdetek: a vírus nagyvárosi terjedése}

\section{Nyugat-európai példák}

A 2019-es évek végén, a 2020-as évek elején kirobbant COVID-19 világjárvány elsősorban a nagyvárosokat, a városi térségeket érintette ${ }^{3}$. A Covid-19 koronavírus egy világvárosban jelent meg és számos nagy városon, azok összekapcsolódott rendszerein keresztül szóródott szét. Az első eseteket 2019 decemberében fedezték fel a több mint tizenegy milliós népességű kínai Vuhan megavárosban, amely Közép-Kína legnépesebb városa, tartományi székhely. 2020. január 31-én az olasz fóvárosban, Rómában jelent meg ugyanez a vírus. Ezt megelőzően egy vuhani kínai pár 2020. január 23-án érkezett meg az olasz nagyváros, Milánó Malpensa repülőterére. A szóban forgó pár ezt követően Veronán, majd Pármán keresztül 2020. január 28-án jutott el Rómába, ahol mind a ketten kórházba kerültek. S bár az olasz fertőzöttség Rómában sem volt elenyésző, kiemelkedő mértékú mégis Lombardia tartományban és annak városaiban lett ${ }^{4}$. A vírus a legnagyobb mértékben a másfél millió lakost számláló Milánóban, Lombardia székhelyén, az ország második legnagyobb városában, ipari, kulturális központjában jelent meg. A fertőzöttség a régióban tovább terjedt: Torinóban, a közel egy milliós, üzleti, kulturális, oktatási központban, megyeszékhelyen, az olasz autógyártás ikonikus városában, majd a közel kétszázezer lakosú Brescia városában jelent meg, amely az ország harmadik legnagyobb ipari központja, de turisztikai látványosság is, köszönve a Garda tó és az Alpok közelségének. A százhúszezer lakosú szintén megye központ, a természeti szépségéről, turisztikai látnivalóiról, különleges fekvéséről, régi városrészeirôl híres Bergamo városában különösen komoly méretû volt a fertőzöttség. A Lombardiában bekövetkezett halálesetek majdnem egyharmadát Bergamóban jegyezték fel: itt két kisebb környékbeli városi kórház volt a fertőzés gócpontja ${ }^{5}$. Ennek 
a városnak a története azért fontos, mert a nagyfokú érintettség mellett sokáig jellemző volt a szakmai bizonytalanság: a veszélyt felismerő orvosok, aggódó, intézkedéseket sürgetô tudósok és tétovázó politikusok vitái lassították a megoldást. Bergamo megyében több mint 3000 ember halt meg az első hullámban ${ }^{6}$. Ausztriába Lombardiából érkezett meg a Covid-19 2020. február 25-én ${ }^{7}$. A betegségben Tirol tartomány volt a legérintettebb, a betegeket a tartomány központjában, az innsbrucki kórházakban kezelték.

A nagyvárosok felsorolását tovább lehet folytatni: 2020. január 24-én a franciaországi Bordeaux-ban, a Bordeaux-i borvidék központjában, egyben történelmi és kulturális centrumban regisztrálták az első öt, szintén Vuhanból érkezett esetet ${ }^{8}$. A vírus Franciaországon belüli terjedése főként a kelet-franciaországi régiókat (Grand Est) érintette. Ezek között kiemelkedő gócpontja volt a vírus terjedésének az autógyártásáról híres Mulhouse városa. A svájci és a német határ menti, az agglomerációjával együtt közel kétmilliós városban 2020. február 17-24. között az ún. Keresztény Nyitott Ajtó Templom éves találkozóját rendezték meg, kb. kétezer ötszáz ember részvételével, a szakértők szerint ezek legalább fele megfertőződött. Ezt követően a fertőzés rohamosan terjedt az egész keleti régióban: 2020. március elejét követóen sokan betegedtek meg a több mint százezres lélekszámú, a hagyományos francia középosztály által kedvelt, történelmi és kulturális örökségéról híres Orléansban, a hasonló népességú Besançonban, amely a rehabilitált történelmi városfejlődés egyik modellje. A regionális fertőzöttség elérte az ötvenezres ipari központot, a megyeszékhely Belfortot is, de a burgundiai borvidék százötvenezres lakosú Dijon városát sem kímélte. Az ország szíve, gazdasági, társadalmi, kulturális központja a közel kétmilliós globális város, Párizs és környező térsége, a több mint tizenkétmilliós Île-de-France régió fertőzöttsége az ország keleti sávjában, de az egész országban is a legnagyobbnak bizonyult ${ }^{9}$. A madridi metropolisz régió helyzete szintén hasonló volt ${ }^{10}$. A német nagyvárosokat nézve (ebben a sorrendben) Berlinben, Münchenben, Hamburgban volt a legmagasabb a fertőzöttség ${ }^{11}$.

Az első hullámot követô második hullámban sem változott meg a nagyobb városok kiemelt sérülékenysége és az ebből adódó nagyobb fertőzöttségi arányok. A járvány időközben tovább terjedt, a kisebb településekre, vidéki városokba, falvakba, a térbeli hierarchiák alacsonyabb szintjein is megjelent. Ma már gyakori, hogy a vidéki települések COVID-19-cel érintettsége nagyobb, mint a nagyvárosoké.

\section{Kelet- és közép-európai példák}

A COVID-19 globális vírusjárvány nem kímélte a kelet- és közép-európai térséget, azok országait, nagyobb városait, közte a Visegrádi országok fővárosait sem. Bár a koronavírus ezekben az országokban jóval később és kevésbé súlyos formában jelent meg ${ }^{12}$. A V4 országok fertőzöttsége között viszont sok különbségeket találunk. A Világgazdaság 2021. január 9-i száma szerint, ha az összes fertőzöttet nézzük egy millió főre vetítetve a sorrend a következő: a legtöbb fertőzött Magyarországon volt (4173 fó), ezt követte Szlovákia (4099 fő), majd Lengyelország (3694 fő) és Csehország (1079 fő) következett ${ }^{13}$.

A magyarországi helyzetről a következőket tudjuk: 2020. december végén a Portfólió szerint Magyarország a világ 40. legfertőzöttebb országa volt a több mint kétszáz ország és autonóm régió között. A koronavírussal összefüggésben elhunytak számát tekintve népességarányosan a 17. helyen álltunk ${ }^{14}$. Ekkor 306368 fő, 2021. január 9-én pedig már 340459 főre nőtt a magyarországi fertőzöttek száma, elhunyt 10554 fó, miközben a gyógyultak száma is folyamatosan emelkedik, jelenleg 193172 fó. Az aktív fertőzöttek száma 136733 személy, 5126 koronavírusos beteget ápolnak kórházban, közülük 365-en vannak lélegeztető-gépen ${ }^{15}$. 2021. január 15-én az országban (a tanulmány befejezésekor) 349149 fertőzött volt ${ }^{16}$. 
A V4 fővárosok fertőzöttségének a nagyvárosi jelleggel összefüggő sajátosságairól keveset lehet tudni. Erre vonatkozóan nem sok adatot találtam, de úgy vélem, hogy a Visegrádi országok fôvárosai, nagyvárosai, turisztikai helyei a lakosság méretei, a népsúrűség alapján hasonló szerepeket játszhattak a vírus terjedés első szakaszában, mint amit a nyugati típusú nagyvárosok eseteiben láttunk. Bár Budapest, Pozsony, Prága és Varsó viszonyai között számos különbség is van, erősek a hasonlóságok is (CSEPELI GY. et al. 2020; SzIRMAI V. 2019). Részben a történelmi múlt, így a keleti-közép-európai urbanizációs modell, a késleltetett városfejlődés közös sajátosságai, részben a mai globális városi rendszerekben elfoglalt hasonlóan megkésett pozíciók miatt.

A négy fóvárosban szinte egy időben, 2020. március elején regisztrálták az első eseteket. A COVID-19 fertőzést Budapestre is behurcolták, több nagyvároson keresztül érkezett ide a járvány. A 444.hu szerint „Magyarországon is járt az a két, amerikai illetve ecuadori egyetemista, akiknél Prágában diagnosztizálták a koronavírus-fertózést. A két nő február 24-én érkezett Milánóból Bécsbe, ahonnan Budapestre, majd Brnón át Prágába utaztak, ahol egy AirBnB-ben szálltak meg. Az amerikai nőnél a vasárnapi első teszt, az ecuadorinál pedig a megismételt laboratóriumi vizsgálat mutatta ki a koronavírust" ${ }^{17}$. A Wikipédia által közöltekből kiderült, hogy az első két személy, akikről Magyarországon hivatalosan bejelentették, hogy COVID-19 koronavírussal fertőzöttek, két iráni származású, Magyarországon tanuló egyetemista volt. Az egyik a Semmelweis Egyetem, a másik, a gödöllői Szent István Egyetem hallgatójaként tartózkodott itt. Az első időszak további egy betege egy 69 éves brit férfi volt, aki a munkája miatt Milánó és Debrecen között rendszeresen ingázott ${ }^{18}$.

A Covid-19 világjárvány első időszakában (2020 májusában) a magyarországi területi adatok azt mutatták, hogy a járvány Budapest esetében volt a legmagasabb. Ezt követték Fejér, Zala, Komárom-Esztergom, Pest megye százezer főre vetített adatai ${ }^{19}$. Budapest akkori nagyobb érintettségét néhány fővárosi idősotthon nagyobb fertőzöttsége okozta. 2020 augusztusában szintén Budapesten, illetve Pest és Fejér megyékben voltak a legmagasabbak a COVID-19 esetszámok. A kutatások az ország nyugati térségeiben szintén nagyobb fertőzöttséget találtak a keleti országrészekhez képest (KovÁcs S.-UzzoLi A. 2020. 161. p.).

2020. május 1. és 16. között került sor az ún. H-UNCOVER vizsgálatra, ahol a cél az aktuálisan aktív SARS-Co-V -2 fertőzöttek, valamint a korábban SARS -CoV-2 fertőzésen átesettek arányainak feltárása volt. A regionális elemzésekből az derült ki, hogy bár a nagy régiók között nem voltak jelentős eltérések, a legmagasabb fertőzöttségi értéket (9,0\%) Budapest esetében mérték (MERKELY B. et al. 2020,549. p.). Egy 2020-as novemberi kutatásból bár hasonló helyzet derült ki, a 2021. január 7-i adatok már új állapotot rögzítettek ${ }^{20}$. Eszerint Győr-Moson-Sopron, Vas és Nógrád megye magas, Budapest és Pest megye jóval alacsonyabb fertőzöttséget mutatott ${ }^{21}$. A 2020. május és 2021. január eleje közötti időszak során Budapest és a vidék adatainak az összevetésekor a fóvárosi adatok javulása, a vidéki adatok jelentős romlása következett be. Ez megfelel a nyugat-európai nagyvárosok és a vidék összevetésekor látott trendnek.

\section{A lehetséges magyarázatok}

Az Economics Observatory szerint a nagyvárosok nagyobb fertőzöttségének az okait azért kell megérteni, hogy visszatérhessünk az eredeti életformáinkhoz, vagy megtaláljuk a megoldásokat a problémamentes nagyvárosi léthez ${ }^{22}$. A COVID-19 vírusjárvány nagyvárosi megnyilvánulásának magyarázata éppen a nagyvárosi jelleg lehet, hiszen ezeken 
a helyeken élnek a legtöbben, itt a legsűrűbb a népesség elhelyezkedése, az épületekkel és egyéb infrastruktúrával való beépítettség itt a legmagasabb, a legelterjedtebb a tömegközlekedés, itt vannak (voltak) a nagy sport és egyéb rendezvények, fesztiválok, politikai tüntetések. Ezek a tömegturizmus célpontjai. Az idős otthonok, ápolási intézmények, de a kórházak többsége szintén a nagyvárosokban található.

A részletesebb elemzésekből azonban kiderül, hogy a városok funkciói, a különböző térségi típusokhoz tartozás differenciáltságokat okoz. A vírus fó célpontjai a „,szupersztár” globális városok, mint New York és London, vagy Párizs, ahol a multikulturalizmus révén sokszínú a népesség, ahol magas a lakosságszám, ahol sűrúk a lakónegyedek, sokan használják a várost és jelentősek (voltak) a turisztikai hatások. A vírus egy másik célpontját, a fertőzöttség másik típusát az olyan ipari központok adják, amelyek ellátási láncokon keresztül kapcsolódnak egymáshoz. A harmadik típust a globális turisztikai központok képezték és képezik, mint Olaszország, Ausztria, Svájc, vagy Franciaország sípályái.

RICHARD FLORIDA a The Geography of Coronavirus (A koronavírus geográfiája) címú 2020-as munkájában (FLORIDA, R. 2020) a vírus terjedésének geográfiai összefüggéseit elemezve leszögezi: bár a nagyobb városok nem immunisak a fertőzéssel szemben, néhány város sokkal kiszolgáltatottabb a vírus pusztító terjedésének. A városok ugyanis nem egyformán sebezhetők. A sebezhetőség a városok nagyságától, a népesség sưrûségétől valamint a nagyvárosi övezetek jellegétől is függ.

Ezt az állítást egy olyan diagrammai igazolja, amely a Covid-19 halálozási arányait mutatja várostérségi méretek, illetve a városok övezeti típusaiként ${ }^{23}$. Ebből kiderül, hogy a nagy metropoliszok vezetik a szomorú listát, a további adatok a nagyváros környéki negyedek lakossági súrúsége szerint alakulnak. A sűrûn lakott elővárosok halálozási adatai, noha alacsonyabbak, mint a metropoliszokban, de magasabbak, mint az alacsony népsűrűségú elővárosokban. A közép- és a kisvárosok adatai még alacsonyabbak, a legkevesebb esetszám a vidéki területeken látható (1.ábra).

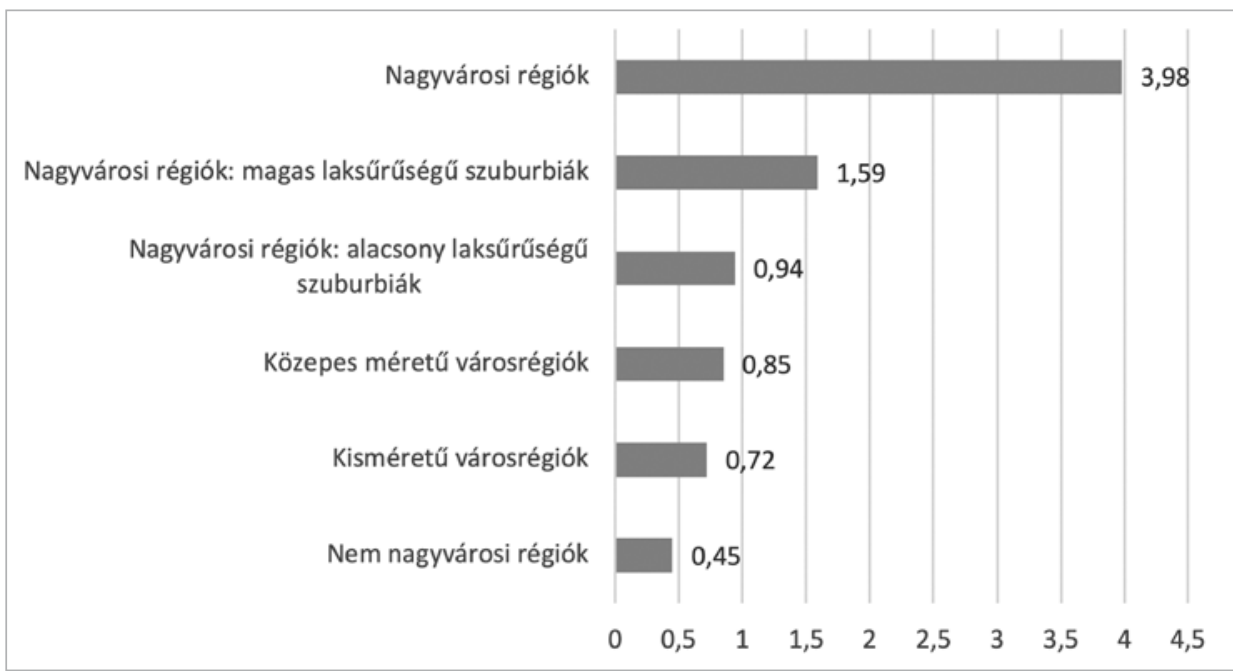

1. ábra A COVID-19 halálozási ráta különböző típusú városrégiókban (\%) (A COVID-19-ben meghaltak/100000 népesség, 2020. április 2-ig) Figure 1 Mortality rate in different types of metropolitan regions (Number of deaths per 100 thousand people caused by Covid 19, until 2. April 2020.) Forrás/Source: New York Times, Cenzus, INDEED

Jegyzet: a város megyék átlagos rátája 2,16, kivéve New York City-t 
Más szakirodalmak is kiemelik a népsűrűség meghatározó jelentőségét, bár egyértelmúvé teszik, hogy a nagyvárosok magasabb fertőzöttségéért nem a népsűrúség, hanem a népsűrûséggel összefüggő szoros emberi kapcsolatok, illetve a zsúfolt életkörülmények, valamint a vírus hatásainak kitett foglalkozások felelősek (STIER, A. et al. 2020).

ANGEL és kutató csoportja nem csupán a népsűrűség mögött meghúzódó (hierarchikus jellegú, eltérő fontosságú) emberi kapcsolatokat, hanem azok intenzitását tartja lényegesnek (ANGEL, S. 2020). Az emberi kapcsolatok intenzitását a város területi kiterjedtsége, a térbeli összefüggések rendszere befolyásolja: eszerint minél kiterjedtebb egy város, minél dinamikusabb az urban sprawl, a munka- és a lakóhely közötti térbeli távolság is nagyobb, s az ebből is adódó szükségszerú utazási idő is több, következésképpen annál nagyobb a fertőzöttség növekedési esélye is. A nagyobb és sűrúbb városokban ezeknek a tényezőknek a hatásait lehet tapasztalni a magasabb esetszámban.

A járvány kibontakozásakor nem értettük, hogy miért sújtja a fertőzés kiemelt mértékben az olasz, vagy a spanyol városokat. Könnyen lehet, hogy az előbb említett tényezó hatása miatt is. A mediterrán népek kultúrája, az intenzív, családi, rokonsági, szomszédsági kapcsolatrendszerek bizonyára szerepet játszhatnak a magasabb olasz, vagy spanyol fertőzöttségi esetek kialakulásában, ahogy az idősebb korosztályok nagyobb arányú jelenléte szintén.

New York állam kormányzója, ANDREw CUOMO 2020. március 26-án azt a kérdést tette fel, hogy miért van egyes amerikai nagyvárosi területeken több fertőzés és több haláleset, mint máshol? A kérdésre a kormányzó egy kutatásokat igénylő hipotézissel válaszolt: vélhetőleg New Yorkban azért van több eset, mint bármely más városban, mert népessége sűrú és mert nagy nemzetközi átjáró ${ }^{24}$. Egész biztos, hogy nem tévedett. Shlomo Angel professzor által vezetett kutatócsoport vizsgálatai ugyanis ezt igazolták (ANGEL, S. 2020).

A New York-i Egyetem Marron Intézete, amely a koronavírus földrajzi elterjedését metropoliszok esetében vizsgálta 2020. március 27-től, a következőket állapította meg: 1) A globalizáció, a globális gazdaság hatásai különös jelentőséggel bírnak a járvány alakulásában. 2) A koronavírus járvány nagyrészt városi járvány: az Egyesült Államokban megerősített esetek 93\%-a metropoliszok területén jelent meg, ezért rendkívül lényeges a világjárvány városokra összpontosított nyomon követése. 3) A több mint nyolcmilliós New York, valamint a több mint három millió lakosú Los Angeles, a több mint nyolcszázezer lakost számláló San Francisco, az egymilliós San José és Washington állam közel hétszáz ezer lakosú városa, Seattle nem epicentrumok, de a világjárvány „élcsapatai” vagy másképpen kifejezve vezető tényezői (vanquardjai). 4) A koronavírus okozta halálozások száma a vizsgált metropoliszok népességétől és a népsûrűségtôl, de fôként a 75 év feletti populáció arányaitól függ. 5) A koronavírus földrajzi elterjedésének eltérései az USA metropoliszainak statisztikai területein meglehetősen pontosan kiszámíthatók, előre jelezhetôk.

STIER és munkatársai szintén a globalizációs faktor hatásait igazolják, amikor a járványt generáló legfontosabb faktornak a városok közötti kapcsolat rendszert, a globális hálózatokat nevezték meg (STIER, A. et al. 2020). AdHIKARI és PANTALEO is hasonlóképpen vélekedtek: az összekapcsoltabb, egyben globálisabb városhálózatok, de különösképpen a nagyobb méretű városok inkább sebezhetőbbek a betegségek által, mint a kisebb városok és a vidéki területek. Ezt az amerikai városok 2020. március 14. és március 19. közötti megbetegedési eseteit elemző munkájuk alapján állították. A vírus reprodukciós rátájának a városi népességhez viszonyított arányát nézve egyértelmúvé vált, hogy a COVID-19 gyorsabban terjed a nagyobb városokban, mint máshol (ADHIKARI, S. - PANTALEO, N. 2020).

Ez különösképpen a járvány kitörésekor volt igaz, ekkor a lakosság nagyobb része gyorsan megfertőződött, főként a népesebb városi területeken. Ezt a problémát az erőteljes távolságtartás járványkezelései követelményével lehet kordában tartani, ez az intézkedés 
képes megszakítani az emberi társadalmak társadalmi hálózatának szerkezetét, különösen a városi területeken. Ezt a szempontot mások is igazolták: egy friss kutatás szerint New Yorkban két és félszer gyorsabban terjedt a betegség, mint Oak Harborban, amely egy negyvenkét ezres kisváros az északnyugati parton, az USA Ohio államában ${ }^{25}$.

Nem szabad elfeledkezni egy további lényeges meghatározóról, mégpedig a megbetegedések szociológiai hátterét adó társadalmi strukturális hatásokról. Ezek azonban még lényegében feltáratlanok, kevés (vagy eltitkolt) az olyan típusú elemzés, amiből a megbetegedettek társadalmi helyzete kiderülhet. Az Amerikai Egyesült Államokban azonban 2020 júliusában (a tanulmány állítása szerint elsôként az USA-ban) tíz metropoliszra kiterjedő felmérés készült, amelyben a társadalmi és a faji meghatározottsági tényezőket keresték.

A vizsgálat az Egyesült Államok tíz nagyvárosának az összesített statisztikai területeinek adataira épül. A mintába Atlanta, Boston, Chicago, Detroit, Los Angeles, Miami, New Orleans, New York City, Philadelphia és Seattle kerültek bele. A statisztikai elemzés a népességszámra, a szegénységi küszöb alatti népesség helyi arányaira, az etnikai hovatartozásra, a jövedelmi adatok vizsgálatára, valamint a százezer lakosra jutó fertőzöttség és elhalálozási adatok rögzítésére terjedt ki. Az eredményeket a JAMA Network Open orvostudományi folyóiratban közölték (ADHIKARI, S.-PANTALEO, N. 2020). Az eredményekre más tanulmányok is felhívták a figyelmet (HENRY, T. 2020).

ADHIKARI és szerzőtársa már a vizsgálatot megelőzően is érzékelték, hogy az afroamerikai lakosságot, a latin népességet és a dél-ázsiai közösségeket az átlagokhoz képest is erősebben érinti a vírusfertőzés. A kutatás során nyilvánvalóvá vált, hogy a COVID-19 fertôzések és halálozások okai összefüggenek a jövedelmi viszonyokkal, illetve, hogy a jövedelemi megoszlások mellett más strukturális tényezők is szignifikáns hatással vannak arra, hogy egy térségben élő egyén megfertőződött-e vagy meghalt-e a COVID-19-ben. Fontos felismerésük volt, hogy a marginalizálódott, a hátrányos helyzetú kisebbségi populációk által lakott területek, ahol a kormányzatok hosszú ideje nem valósítottak meg térségi szintú fejlesztéseket, a legsúlyosabban érintettek a vírusfertőzéssel. Itt voltak a legmagasabbak a halálozások is az USA nagyvárosi területein. Az is kiderült, hogy azokban a megyékben, ahol a lakosság lényegében nem volt fehér és a mediánjövedelem csupán 60,240 dollárt tett ki, a COVID-19 halálozási arány több mint kilencszer magasabb volt, mint azokban a megyékben, amelyek fehérek által lakottak voltak, miközben azonos medián jövedelemmel rendelkeztek. Ez az etnikumokhoz tartozás meghatározó jelentőségét mutatja a fertőzöttség alakulásában. Bebizonyosodott az is, hogy a fertőzés aránya közel nyolcszor magasabb volt a faji és etnikai szempontból sokszínúbb, egyben nagyobb szegénységnek kitett térségekben, mint a faji illetve etnikai szempontból homogénebb területeken. A vizsgálat azt is igazolta, hogy a faji egyenlőtlenségek nem tûntek el a magasabb jövedelmú megyékben, ott sem, ahol a mediánjövedelem 79834 dollár volt. S ez azt jelenti, hogy a társadalmi strukturális tényezők kiemelt szerepet játszanak abban, hogy a marginalizált és kisebbségi csoportok élet- illetve fertőzöttségi kilátásai rosszabb kimenetelűek. Végül a kutatás azt is feltárta, hogy a COVID-19 fertőzés és a halálozási arány közel háromszor magasabb volt azokban a nem fehérek által lakott megyékben, ahol magasabb volt a medián jövedelem, mint a fehér, szintén magasabb jövedelmú megyékben. A jövedelem tehát nem tudta eliminálni a faji egyenlőtlenség hatásait.

A szerzők a jövőre vonatkozó javaslatokat is tettek: 1) További kutatások segítségével fel kell tárni, hogy a strukturális rasszizmus mennyiben játszik szerepet a fertőzések és a halálozás aránytalan különbségében, a sokszínúbb közösségek és a fehér lakosú közösségek között. 2) Meg kell vizsgálni a háztartások zsúfoltságából, a munkavállalók arányaiból, de a tömegközlekedéssel közlekedők számából, az egészségügyi ellátáshoz való hozzáfé- 
rés különbségeiből fakadó hatásokat. 3) A feltárt tényadatokat a járványügyi egyenlőtlenségek kezelésére törekvő politikák keretében is alkalmazni kell. 4) Létfontosságú, hogy a kormányok többet tegyenek a faji megkülönböztetések enyhítésért. 5) A járványügyi intézkedések vegyék figyelembe az egészségügyi egyenlőtlenségek strukturális tényezőit és a társadalmi meghatározókat is.

A vírusfertőzöttség és a társadalmi egyenlőtlenségek összefüggéseit egyéb kutatások is jelezték. A WorLd ECONOMIC ForUm (2020) elemzése arra mutatott rá, hogy a vírus egyenetlen hatást gyakorolt a különböző társadalmi csoportokra, még ugyanazon a városon belül is. Amikor New York City volt a világjárvány világméretű központja, Manhattan belvárosának fertőzési aránya nagyjából 925/100 000 volt, addig Queensben, amely New York város egyik külső kerülete és ahol a több mint két milliót számláló lakosság fele bevándorló, számuk százezer foore vetítve 4125 fő volt. Egy másik példából hasonló helyzet derül ki: a 2020. szeptember 4-i adat szerint a tizennyolcmilliós indiai nagyváros Mumbai (gyarmatkori nevén Bombay) hétmilliós nyomornegyedének több mint fele fertőződött meg a COVID-19 vírussal. Ezeknek a különbségnek az oka egyértelmú: New York, vagy más világváros leggazdagabb lakói hozzáférhetnek az egészségügyi szolgáltatásokhoz és módjuk volt otthon dolgozni, addig a hátrányos helyzetű városrészekben élőknek erre nincs lehetôségük.

A szegénység és a kedvezőtlen lakóhelyi körülmények és a vírus fertőzöttség lehetséges összefüggéseit magyar kutatások is jelezték, jóllehet (ahogy azt már korábban említettem) a már megfertőzöttek társadalmi, strukturális helyzetét ezek a munkák sem elemezték, de egyéb, lényeges összefüggéseket igazoltak. Az egyik kutatás Józsefváros viszonyait, a járvány gazdasági hatásait jelző társadalmi problémákat nézte 600 fős mintán, 2020. július 13. és 17. között. A kutatási dokumentációból kiderül, hogy „Józsefváros sok szempontból Budapest egyik leghátrányosabb helyzetú negyede. Bár az elmúlt két évtizedben több gazdasági és szociális mutató is javult, a legmélyebb társadalmi problémákat így a szegénységet, a lakhatási válságot, a szociális és egészségügyi egyenlőtlenségeket nem sikerült érdemben kezelni”. Ezeket a szempontokat tekintve tehát „,Józsefváros fokozott kockázatnak volt kitéve a járvány időszakában" - állítja a két szerző (HUNYADI B.-MoLNÁR Cs. 2020.9. p.). BALÁZS ANDRÁs írása a Magdolna negyed példáján mutatja be a nagyvárosi szegénység és a vírusjárvány okozati összefüggéseit ${ }^{26}$. A szerző arra kíváncsi, hogy a vírusjárvány hogyan érintheti a nagy városok szegény csoportjait. A válasz az, hogy ,ahol nagyobb a szegénység, ahol magas az egyszobás és az alacsony komfortfokozatú lakások aránya, ahol a lakásokban jellemzően több ember zsúfolódik össze és ezért a lakosok egy része többet tartózkodik az utcán, a fertőzést is nehezebb elkerülni” (BALÁzs A. 2020, 2. p.). A Tárki 878 fős COVID 2020 vizsgálatát azért érdemes még itt felidézni, mivel széles keretben elemezte a járvány gazdasági, társadalmi egyenlőtlenségeket generáló hatásait, illetve a járvány elleni védekezés mentális következményeit, az egyéni bezártság, a jövedelem csökkenés következményeit (TóTH J.GY.-HuDÁcSKó Sz. 2020).

A 444.hu hasábjain 2021.február 16-án egy nagyon lényeges elemzés jelent meg. A KSH 2019-es és 2020-as negyedik negyedévét összehasonlító adatokra hivatkozva megállapítják, hogy „Messze Szabolcs-Szatmárban volt a legrosszabb a Covid-fertőzöttek túlélési esélye, Budapesten a legjobb". A közölt ábrák részletes bemutatására nincs módom (mivel ezek az információk a tanulmányom tördelésének az időszakában jelentek meg) de azt mindenképpen kiemelem, hogy a Szabolcs Szatmár-Bereg, majd Nógrád megyében legmagasabb, és a többi megyében fokozatosan csökkenő, Budapesten pedig a legalacsonyabb különböző vírus fertőzöttségi mutatók nemcsak az egészségügyi ellátottság, hanem a társadalom térbeli elhelyezkedésének (iskolázottság, jövedelem, egészségi állapot szerinti) hierarchikusan egyenlőtlen rendjét is kifejezik. 


\section{A térbeli társadalmi szerkezet átalakulása}

A COVID-19 világjárvány térbeli társadalmi folyamatokat módosító hatásairól csupán hipotéziseket fogalmazhatunk meg, hiszen ma még (sajnos) a járvány közepén, talán újabb hullámok előtt vagyunk. A világ még a járvány elleni védekezéssel, az egészségügyi problémákkal, a vakcinák kifejlesztésével és gyártásával, a tömeges oltás megszervezésével van elfoglalva. A hosszú távú védelem megalapozása érdekében mégis végig kell gondolni a lehetséges területi következményeket. Ezek a véleményem szerint a következőek lehetnek:

1) A nagyvárosi életforma és környezet értékvesztése, a nagyvárosi élet presztízsének csökkenése az egyik elképzelhető folyamat. A vírus fertőzések magasabb nagyvárosi arányai, az ebből adódó korlátozottságok, a nagy városi élet korábbi előnyeinek a viszszaszorulása, de főként a betegségektől való félelmek a középosztálybeliek egy részét elfordíthatják a nagyvárosi életformától. Mindez a kiköltözésüket is motiválhatja.

2) A dzsentrifikáció lassulása, akár leállása szintén feltehető opció, amelyet a nagyvárosi középosztály vírusfertőzéssel kapcsolatos félelmei, a nagyvárosok korábban előnyös életformákat biztosító intézmények mûködésének a visszaszorulása, a szuburbanizációs trendek dinamizálódása is okozhatja.

3) A leromló, nagyvárosi szegénynegyedek, slumok számának a növekedése is elképzelhető. A nagyvárosi középosztály (fóként alsóbb csoportjainak) a kiköltözése, a különböző városfejlesztési projektek leállása miatt egyes nagyvárosi negyedek ingatlanárai csökkenhetnek, ami térbeli társadalmi átrendeződést, az alacsonyabb társadalmi státusúak beáramlását, növekvő szegregációt is eredményezhet.

4) A szuburbanizáció felgyorsulása szintén lehetséges, részben a középosztály nagyvárostól való elfordulása, részben pedig a nagyvárosi munkájukat elvesztett rétegek kiábrándultsága okán. Egy amerikai elemzés szerint az ún. milleniumi (másképp az Y) generáció tagjainak új lakóhelyi igényei szintén a szuburbanizációt gyorsító tényezők ${ }^{27}$. Ez a réteg többnyire kényszerből, a korábbi nemzedékhez képest jóval alacsonyabb jövedelmi viszonyai miatt változat a lakóhelyén, miközben a fogyasztási szokásait is visszafogja (MCCARTHY, K. 2020).

5) A külvárosi fejlődés dinamizálódását, a városi terjeszkedés növekedését nemcsak a nagyvárostól való elfordulás, hanem az ingázó életformával szembeni ellenkezés is kiválthatja. McCarthy szerint azok a fiatalok is célba vehetik a külvárosokat, akiknek elegük van a napi ingázásból. Az ingázási idő csökkentésének egyik módja a munka- és a lakóhely közelítése.

6) A globális gazdaság új területi igényei, egyes cégek vidéki telephely választásai, az otthoni munkavégzés terjedése, a meglévőktől eltérő munkahelyeket, új típusú, kisebb méretú irodaházakat igényel. Ezek kialakítására a külvárosok, az elővárosok jó feltételeket nyújtanak.

7) McCarthy szerint a 2020 utáni évek külvárosa már nem olyan lesz, mint volt. Több mindent helyben fog biztosítani a lakóinak: otthont és munkahelyet, a nagyvároshoz való közelséget, kényelmet és megfizethető életformát is. (Erre törekedett a 19. században a howardi kertvárosi mozgalom is, nem sok sikerrel.)

8) A vidéki, a kisebb városi életformák és életkörülmények felértékelődése szintén reális folyamat. Erre vonatkozó törekvéseket már korábban is érzékelni lehetett: a nagyvárosokban élő középosztálybeliek közül számosan vettek vidéki vagy városkörnyéki házakat, amelyeket (többnyire) második otthonként használnak. A nagy városban munkájukat elvesztettek közül sokan szintén az olcsóbb lakhatást biztosító vidéki településekre költözhetnek, vagy szülőfalujukba telepedhetnek vissza. Ennek is vannak előzményei. 
9) Az itt vázolt hipotetikus folyamatok (esetleg azok némelyike) új térbeli társadalmi szerkezetet alakíthat ki, ami módosíthatja, megakaszthatja a globális urbanizáció eddig ismert negyedik szakaszát, a globalizált urbanizáció (mások szerint a re-urbanizáció) folyamatát, ismételt decentralizációt okozhat. De egy új (akár ötödiknek is nevezhető) olyan urbanizációs szakasz szerveződését is eredményezhet, amelyik a korábbi fázisokat ötvözi.

10) Összegezve az eddigieket: feltehető, hogy a nagyvárosokban jelentős társadalmi strukturális átalakulások jönnek létre, a COVID-19 vírusjárvány komplex, egészségügyi, demográfiai, gazdasági és társadalmi konfliktusokat is generáló következményei, azok kumulatív hatásai miatt, amelynek során a szegénységben élők köre szélesedhet, a középosztály aránya csökkenhet, a térbeli, társadalmi demográfiai egyenlőtlenségek növekedhetnek, a társadalmi polarizáció pedig éleződhet.

\section{Összefoglalás: A megoldás elvi lehetóségei}

A vírussal küzdő nagy városi problémák megoldásához szükség van a különböző területi tudományok, a geográfia, a városszociológia, a várostervezés együttmúködésére, illetve a megoldások keresésére. SASKIA SASSEN meg is próbálkozik ezzel.Érdemes összefoglalni, mit javasol a globális város elmélet kidolgozója (SASSEN, S. 2020):

1) Sassen egy vele készült interjú során javasolta, hogy „,sok új ésszerű méretű várost kell építenünk, amelyek lehetővé teszik a lakók jobb életét, nem kényszerítik őket nagyon hosszú ingázásokra" (BASSETTI, F.2020).

2) Sassen szerint legyen a cél mindenki jól-léte, a gazdagság előteremtésének nem kell prioritásokat adni. Nem redukálhatjuk a városokat a „pénzteremtők státuszává, pedig manapság egyre több nagyvárosunkkal ez történik" - állítja. Nem is alaptalanul: a mai nagyvárosok többsége bár erôsen polarizált, túlnyomóan dzsentrifikált, ahol a vírus fertőzéssel leginkább sújtott szegény negyedek is megtalálhatók.

3) A szociológusnő a rugalmasság, az alkalmazkodás képességének a megteremtését és a helyi társadalmi élet erősítését is lényegesnek tartja. Ezért mindenkit arra ösztönöz „hogy jobban kötelezzék el magunkat szomszédjaikkal és a helyi környezettel, az utcákkal, a kis, belső terekkel. Ez abban is segíthet, hogy jobban törődjünk egymással, hogy csökkenteni tudjuk a természeti környezet agresszív kihasználását, a nagyvárosi emberek közötti agresszív kapcsolatokat " (BASSETTI, F. 2020).

Ehhez hozzá kell tenni, hogy ennek az elvnek a megvalósulása elképzelhetetlen a várostervezés, városfejlesztés modernizálása, a városlakók érdekeit, mindennapi életét, egészségét jobban szolgáló, humánusabb városfejlesztési gyakorlat megalapozása nélkül. Napjaink tervezési gyakorlata fóként a gazdasági elvárásokra, a befektetők, az ingatlanfejlesztôk igényeire épít.

4) Az amerikai szociológus arra is felhívja a figyelmet, hogy ,globálisan és a WHO európai régiójában szintén a városi önkormányzatok és a helyi közösségi szervezetek kulcsfontosságú szereplők a hatékony válaszban, már ma is számos országban élen járnak a járvány visszaszorításában.” Ez a szempont a keleti típusú városfejlesztési modell számára különösen fontos, hiszen a meglévő hiányosságokat pótoló, az együttmúködést támogató javaslatról van szó..

5) A városok társadalmi, gazdasági jelentőségét továbbra sem szabad megkérdőjelezni - hangsúlyozza Sassen: „mivel a városok a mai világ mindenképpen meghatározó tényezői, s bár könnyen kritizálhatók, de a kedvezőtlen kihívások megoldását is azok kínálják" (SASSEN, S.2020). Florida szintén kiemeli a nagyvárosok pozitív szerepét, 
hiszen ,,a világ ötven legnagyobb metropolisza, ahol a világ népességének hét százaléka él, a globális gazdasági aktivitás 40\%-át teremti meg (FLORIDA, R. 2017, 9).

6) A nagyvárosi tér jelentóségét az is alátámasztja, hogy csak a városoknak, a fejlett településeknek, az erősebb régióknak van az esélyük a megoldásokra. Ennek okát a Portfolió egyik írása abban látja, hogy ,a fejlett régiókban viszonylag könnyebben alkalmazkodnak az új helyzetekhez az emberek és a vállalatok, mint a lemaradó, leszakadó régiókban" 28.

7) Történészek szerint a városokat már csak azért is meg kell védeni, újra kell szervezni, hogy nehogy oda jussunk, ahová számos letúnt korszak városai jutottak, a romlásba, vagy az eltűnésbe (RoBInSON, A. 2020; WoOLF, G.2020).

8) A városok innovatív képességében többen is bíznak. Foster például a világtörténelem nagyvárosokat érintő problémáit, a 17. századi nagy londoni túzvészt, a 19. századi kolera járványt, az 1952-es nagy londoni szmogot veszi sorra és mutatja be azok kezelésére létrejött technikai innovációkat, amelyek az akkori bajban is létrejöttek és mai helyzetben is létre jöhetnek (FOSTER, N.2020). A történelmi tapasztalatokkal bátorítja a jelen városlakóit, mondván, hogy a ,jövő nem a két méteres távolságtartás”. Ezt bizonyítja, hogy az utolsó, 1918-20-as világjárvány elhagyatott városközpontokat, arcmaszkokat, karanténokat hozott létre. De az 1920-as évek már társadalmi és kulturális forradalmat, újonnan épített áruházakat, mozikat, stadionokat eredményeztek.

9) A globalizációellenesség is erősödik a vírusjárvány következtében. Ez nemcsak a nagyvárosok létét, hanem a védelmet is fenyegeti, mivel a határok lezárását, a munkaerő és a tudás, a járvány megoldásához nélkülözhetetlen tudományos eredmények szabad áramlásának a beszüntetését is jelenti. FALUS ANDRÁs immunológus szerint a ,járványra a megoldást a globalizáció, a közös együttmúködés és nem a bezárkózó társadalmi élet adhatja" ${ }^{29}$. Ebben a városhálózatoknak kiemelkedő szerepe lehet. Ezzel maradéktalanul egyet tudok érteni.

10) A World Economic Forum Akció Programja három tényezőt emelt ki a vírus járvány enyhítése érdekében: 1) tudomásul kell venni, hogy a COVID-19 járvány nem egyszerúen a városokat, hanem a szegényebb, túlzsúfolt városrészeket érintette a legsúlyosabban; 2) a társadalmi-gazdasági tényezők kulcsfontosságú meghatározói a fertőzés kockázatának; 3 ) a világjárvány megfékezése érdekében szükség van a társadalmak újra formálására. Ez azonban csak magukból, a városokból indulhat $\mathrm{el}^{30}$.

Végezetül: az itt közölt javaslatokkal, különösképpen a legutolsóval alapvetően egyet értek, mivel fontos szempontokat fogalmaznak meg. Bár a megvalósításuk nem könnyú és nem is rövid távú feladat. Hogy megvalósíthatók? Majd meglátjuk. De akadnak azért kétségeim is, hiszen bizonyára lehet kisebb városokat építeni, kisebb negyedeket fejleszteni, de mi lesz a már meglévő, terjeszkedô nagyvárosokkal, azok mögöttes érdekstruktúráival? Itt még hiányoznak a kimunkált válaszok, amihez a tudomány, a politika, a gazdaság és a társadalmak közösen kimunkált megoldásai szükségesek. Egy dologban azonban biztos vagyok: a COVID-19 és az egyéb hasonló járványok megoldásának a céljai nem választhatóak el a társadalmi jellegú beavatkozásoktól: a térbeli és társadalmi egyenlőtlenségek enyhítése, a széles körű társadalmi jól-lét megteremtése nélkül nem lesz módunk a természettel is harmonizáló, jobb emberi élet megteremtésére.

SZIRMAI VIKTÓRIA

Társadalomtudományi Kutatóközpont, MTA Kiváló Kutatóhely, Budapest szirmai.viktoria@tk.hu 


\section{IRODALOM}

CSEPELI GY.-ÖRKÉNY A.-Zsigó T. F. 2020: Közép-európai fővárosok mentális térképei -Attitűdök, értékek, identitások. Kultúra, közösség és társadalom. 56-74 p.

FLORIDA, R. 2005: Cities and the Creative Class. - Taylor \& Francis Ltd. 208 p.

FLORIDA, R. 2017: The New Urban Crisis. - ONEWORLD 341 p.

Glaeser, E 2020: A város diadala. - Pallas Athéné Könyvkiadó, Budapest.

HunYADI B.-MoLNÁR Cs. 2020: A koronavírus-járvány gazdasági és társadalmi következményei Józsefvárosban. Political Capital, Budapest.

Kovács Z. 2017: Városok és urbanizációs kihívások Magyarországon. Magyar Tudomány 178. 3. 302-310 pp.

Kovács S. Zs.-Uzzoli A. 2020: A koronavírus járvány jelenlegi és várható egészségkockázatainak területi különbségei Magyarországon. Tér és társadalom 34. 2. pp. 155-171.

Merkely B.-FülöP G. Á-KoszTin A.-Vokó Z 2020: A COVID-19 járvány Magyarországon és a H-UNCOVER vizsgálat. In: KolOSi T.-SzELÉNYi I.-TóTH I. GY.: Társadalmi riport. pp. 543-553.

Mollenkopf, J. H.-Castells, M. 1991: Dual City. Restructuring New York. Russel Sage Foundation, New York.

SASSEN, S. 1991: Global City: New York, London, Tokyo. Princeton University Press.

SzIRMAI V. (szerk.) 2009: A várostérségi versenyképesség társadalmi tényezői. Hogyan lehetnek a magyar nagyvárosok versenyképesebbek? Dialóg Campus Kiadó, Pécs-Budapest

SzIRMAI V. (ed.) 2011: Urban Sprawl in Europe: Similarities or Differences? Aula Kiadó, Budapest.

SzIRMAI, V. 2019: Városok és városlakók (A befogadó és a kirekesztő városok). - Corvina Kiadó, MTA TK, Budapest.

Urban Europe 2016: Statistics on cities, towns and suburbs, Edition Eurostat Statistical Book.

TóTH I. GY-HudÁcsKó Sz. 2020: A koronavírus-járvány gazdasági és társadalmi következményei: az érintettek megoszlása és véleménye a járványt kísérő intézkedésekről. - In: KoLOSI T.-SzELÉNYI I.-TóTH I. GY.: Társadalmi riport 2020. - pp. 553-573.

Woolf, G. 2020: The Life and Death of Ancient Cities: A Natural History. - Oxford University Press, Oxford.

\section{Internetes források}

Adhikari, S.-PAntaleo, N. 2020: Assessment of Community-Level Disparities in Coronavirus Disease 2019 (COVID-19) Infections and Deaths in Large US Metropolitan Areas 2020. JAMA network Open. https://jamanetwork.com/journals/jamanetworkopen/fullarticle/2768723?resultClick=1

Angel, S.-Alejandro, M.-Blei, A.-Lamson-Hall, P.-Tamayo, MMS.: The Coronavirus and the Cities Explaining Variations in U.S. Metropolitan Areas. Working paper.

https://marroninstitute.nyu.edu/uploads/content/The_Coronavirus_and_the_Cities\%2C_27_March_data \%2C_final_draft_31_March_2020_VersApril3.pdf

Angel, S. 2020: On the Spatial Structure of the Covid-19 Pandemic.Some Scale and Density Effects, NYU Marron Institute of Urban Management. https://marroninstitute.nyu.edu/papers/on-the-spatial-structure-of-the-covid-19-pandemic

BALÁZS A. 2020: Vírusjárvány és városi szegénység. A nagyvárosi szegény csoportok egészséghátrányai a Magdolna negyed példáján. https://szociologia.tk.mta.hu/uploads/files/BalazsAndras_Virusjarvany_es_varosi_szegenysegpdf

Bassetti, F. 2020: Urban Migrations and Sustainability in a Post-Pandemic World Foresight. https://www.climateforesight.eu/cities-coasts/urban-migrations-and-sustainability-in-a-post-pandemic-world

FLORIDA, R. 2020: The Geography of Coronavirus. Bloomberg CITYLAB. https://www.bloomberg.com/news/articles/2020-04-03/what-we-know-about-density-and-covid-19-s-spread

FOSTER, N. 2020: The pandemic will accelerate the evolution of our cities. https://www.theguardian.com/commentisfree/2020/sep/24/pandemic-accelerate-evolution-cities-covid-19- norman-foster

HENRY, T.A. 2020: Data from 10 cities show COVID-19 impact based on poverty, race https://www.ama-assn. org/delivering-care/health-equity/data-10-cities-show-covid-19-impact-based-poverty-race

MCCARTHY, K. 2020: Urban to suburban: the growing shift to the suburbs as COVID-19 changes the way people live. https://www.cushmanwakefield.com/en/insights/covid-19/the-edge-volume-4/urban-to-suburban-thegrowing-shift-to-the-suburbs-as-covid-19-changes-the-way-people-live

RoBinson, A 2020: How did ancient cities weather crises? Book review. https://www.nature.com/articles/d41586-020-02070-5

SAsSEN, S. 2020: The City and The Virus. https://www.iberdrola.com/shapes-en/saskia-sassen-crisis-coronavirus

StIER, A.-Berman, M.G.-BettenCOURT, L. 2020: COVID-19 attack rate increases with city size, MEDRXIV BMJ Yale. https://www.medrxiv.org/content/10.1101/2020.03.22.20041004v2

World Economic Forum 2020: Coronavirus hasn't killed the city. Here's why https://www.weforum.org/agenda/2020/09/inclusive-cities-post-pandemic/ 


\section{VÉGJEGYZET}

1 https://www.berghahnjournals.com/view/journals/democratic-theory/7/2/dt070207.xml

2 https://www.vg.hu/velemeny/a-kozgazdaszok/a-covid-varos-2-3051359/

3 Ennek a résznek a rövidebb, kidolgozatlanabb formáját lásd: Szirmai V. (2020): A nagyvárosok: búnösök vagy a kilábalás ígéretei? SOCIO. HU: TÁRSADALOMTUDOMÁNYI SZEMLE: 2 pp. 192-194. , 3 p

4 https://www.statista.com/statistics/1109295/provinces-with-most-coronavirus-cases-in-italy

5 https://infostart.hu/kulfold/2020/03/24/tragikus-a-kep-amit-bergamorol-festett-a-varos-polgarmestere

6 Az olaszoknak elsőként kellett egy olyan helyzettel szembenézniük, amilyenre addig nem volt példa, de végül viszonylag gyorsan lezárták az országot. A fő probléma a döntés meghozatala volt, nem akarták alkotmányos jogaikban korlátozni az állampolgárokat. Mindazt, ami akkor történt, azóta is elemzik. Most a New York Times írta meg saját nyomozásuk eredményét. https://444.hu/2020/12/03/mi-tortent-bergamoban-az-elso-hullamban

7 https://hu.wikipedia.org/wiki/2020-as_COVID\%E2\%80\%9319-koronav\%C3\%ADrus-j\%C3\%A1rv\%C3\% A1ny_Ausztri\%C3\%A1ban

8 https://en.wikipedia.org/wiki/COVID-19_pandemic_in_France

9 https://www.sortiraparis.com/news/in-paris/articles/210162-coronavirus-the-situation-in-paris-and-ile-deFrance/lang/en

10 https://en.wikipedia.org/wiki/COVID-19_pandemic_in_the_Community_of_Madrid

$11 \mathrm{https} / / \mathrm{www}$. statista.com/statistics/1105401/coronavirus-covid-19-cases-cities-districts-germany/

12 https://www.vg.hu/kozelet/egeszsegugy-kozelet/hazankban-harmadannyi-az-uj-koronavirus-aldozata-m

13 https://www.vg.hu/kozelet/egeszsegugy-kozelet/hazankban-harmadannyi-az-uj-koronavirus-aldozata-m

14 https://www.portfolio.hu/gazdasag/20201230/merlegen-a-koronavirus-magyarorszag-a-vilag-legros

15 https://koronavirus.gov.hu/cikkek/2-716-fovel-emelkedett-beazonositott-fertozottek-szama-es-elhunyt

16 https://koronavirus.gov.hu/cikkek/

17 https://444.hu/2020/03/03/budapesten-jart-a-napokban-a-pragaban-koronavirussal-diagnosztizalt-ket-diak

18 https://hu.wikipedia.org/wiki/2020-as_COVID\%E2\%80\%9319-koronav

19 https://en.wikipedia.org/wiki/COVID-19_pandemic_in_Hungary\#/media/File:Covid-19-9.5.png

20 Hungary coronavirus (COVID-19) cases by county 2020 Statista.htm

$21 \mathrm{https} / / /$ koronavirus.gov.hu/terkepek/fertozottek

$22 \mathrm{https} / /$ www.coronavirusandtheeconomy.com/question/why-has-coronavirus-affected-cities-more-rural-areasí

23 https:/www.bloomberg.com/news/articles/2020-04-03/what-we-know-about-density-and-covid-19

$24 \mathrm{https} / / / \mathrm{marroninstitute}$.nyu.edu/blog/the-coronavirus-and-the-cities

25 https://www.futurity.org/covid-19-big-cities-2328792/

26 https://szociologia.tk.mta.hu/uploads/files/BalazsAndras_Virusjarvany_es_varosi_szegenysegpdf

27 A millenniumi generáció az 1981 és 1996 között születettek csoportja. A 2019-től a rendelkezésre álló népességi adatok szerint az USA legnagyobb korcsoportja.

28 https://www.portfolio.hu/gazdasag/20201207/szornyu-csapdaba-kerulhetett-magyarorszag-nehany-regioja-460218

29 https:/qubit.hu/2020/05/21/falus-andras-nagy-felelmem-hogy-meg-tobb-aldozat-lesz

30 https://www.weforum.org/agenda/2020/09/inclusive-cities-post-pandemic/ 


\title{
A SZÁLLÍTÁSI INFRASTRUKTÚRA FEJLESZTÉSE ÉS A GEOPOLITIKA ÖSSZEFÜGGÉSEI A NYUGAT-BALKÁNON
}

\author{
REMÉNYI PÉTER - CSAPÓ DÁNIEL GÁBOR
}

THE RELATIONSHIP BETWEEN THE DEVELOPMENT OF TRANSPORT
INFRASTRUCTURE AND GEOPOLITICS IN THE WESTERN BALKANS

\begin{abstract}
The geopolitical significance of the Balkans can be observed throughout the majority of its history deriving mainly from its relative position between continents, close to strategic maritime and land routes. In certain political circumstances this position attracted regional and great powers which resulted in their direct involvement in "Balkan affairs", which was made easier by the fragmented ethnic and political nature of the region. One particular field of involvement has been the construction of strategic transportation infrastructure which characterizes the current situation as well. After briefly touching upon the general geopolitical significance of transportation, we argue that the examined external powers (the EU, Russia, China, and Turkey) involved in planning and financing the ongoing infrastructure development in the Western-Balkans are doing so in a geopolitical framework, where the investments also aim to bolster the influence of the investor country in the region. The priorities and logic behind these moves can differ, but all actors use infrastructure as an overtly expressed field of their strategies.
\end{abstract}

Keywords: Western Balkans, transportation infrastructure, geopolitics

\section{Bevezetés}

A Balkán történelme során számos alkalommal vált (nagy)hatalmak versengési terepévé, melynek egyik oka a kedvező fekvése a stratégiai útvonalak közelében, nagyhatalmi érdekszférák metszéspontjában. A másik ok a térség fragmentáltsága, mely az erôs belső politikai centrum kialakulását is megnehezítette és megkönnyítette a külső behatolást. A külsố szereplők számára a Balkán sokszor kapcsolati területként jelent meg, inkább eszközként, mint célként tekintettek rá. Napjaink térségbeli versengése is hasonló elvek szerint alakul, aminek a szállítási infrastruktúra fejlesztése az egyik legtérbelibb és leglátványosabb eleme.

Célunk, hogy az elmúlt évek új hidegháborús narratívájához (pl.: KEMP, J. 2020; KAPLAN, R. D. 2019; ERLANGER, S. 2018) kapcsolódóan megvizsgáljuk, hogy a Balkán nyugati, instabil felén hogyan jelenik meg a nagyhatalmi verseny a közlekedési infrastruktúra területén. Úgy véljük ez az egyik „legföldrajzibb” eleme a vetélkedésnek, ennek a legjelentősebb a térbelisége és ez egy viszonylag stabil elem, szemben egyéb területekkel (kultúra, gazdaság, politika...), ahol évról évre sokat változhatnak a folyamatok például egy választási eredmény függ vényében. Így - bár tisztában vagyunk ezen területek jelentőségével is - ezeket kevésbé tartjuk földrajzi elemeknek, így tudományunk eszközeivel csak korlátosan tartjuk vizsgálhatónak.

Jelen írásban elsốsorban az érintett szereplők releváns dokumentumait, a hivatalos politikákat, fejlesztési stratégiákat és az ezekhez kapcsolódó narratívákat vizsgáltuk meg. Ezeket igyekeztünk konkrét, a statisztikákban, terepi megfigyelésen, hivatalos kommunikációban és a médiában megjelenő esetekkel alátámasztani, de ezek szisztematikus számbavétele további terepi vizsgálatokat igényel, mely jelenleg nem áll módunkban.

Munkánk térbeli kereteit legpontosabban a jelenleg nem EU-tag, teljes terjedelmükkel Európában található balkáni államok (Bosznia-Hercegovina, Montenegró, Koszovó, 
Albánia, Észak-Macedónia, Szerbia) körülírással adhatjuk meg. Az egyszerűség kedvéért ezt az országcsoportot nevezzük Nyugat-Balkánnak jelen írásban. Tisztában vagyunk a fogalom ellentmondásosságával, érdekvezérelt jellegével (PAP T. 2019) és azzal is, hogy eredeti jelentésében Horvátországot is magában foglalta. Ugyanakkor elemzésünk céljai szempontjából a legizgalmasabb terület éppen a (még) nem uniós államok köre, ahol a többi érdekelt hatalmi központ is ,,szabadabban” érvényesítheti érdekeit. A szállítási infrastruktúra jellegéből adódik ugyanakkor, hogy időnként a szűken vett célterületen kívülre is kell tekintenünk, hiszen a térségen kívüli forrás- és célterületek ismerete nélkül bizonyos irányok és nyomvonalak csak nehezen értelmezhetők.

\section{Közlekedés és geopolitika}

Modern közlekedési rendszerek nélkül nincs modern társadalom, mind a gazdaság, mind az állampolgárok számára megkerülhetetlen szektor. Politikai földrajzi megközelítésben az államok stabilitása, a politikai centrum terület feletti kontrollja szintén megkívánják a hatékony közlekedést, a modern állam területét a közlekedési hálózat kapcsolja oikumenévé (WhitTlesey, D. 1939, 1999). Politikai földrajzi jelentőségét az Egyesült Államok Transzkontinentális vasútvonala, vagy a hálózat polgárháborúban játszott szerepe (WHITTLESEY, D. 1939, 1999), a Transzszibériai vasút orosz expanziót támogató hatása (ERDősi F. 2015), avagy a brazil transzamazóniai pályák kérdése (WALKER, R. et al. 2011) is mutatja.

Klasszikus geopolitikai gondolkodók A. T. MAHANTóL (1890) a közlekedés módjait, jellemzőit is vizsgálva alkották meg modelljeiket, a hajózási útvonalak, a különböző tengerszorosok kérdése, majd az épített csatornák mindig kiemelt stratégiai jelentőségúek voltak. H. J. MACKINDER $(1904,1999)$ világképében a szárazföldi hatalom szempontjából a vasút volt fontos elem, a 20. század elejétől pedig a repülés vált geopolitikailag és stratégiailag meghatározó közlekedésnemmé (SzILÁGYI, I. 2018). Nagytérségi, birodalmi törekvések a transzkontinentális infrastruktúra fejlesztésében több esetben vezettek geopolitikai feszültségekhez. A Fokváros-Kairó vasútvonal brit terve francia érdekeket sértett, a Berlin-Bagdad vasút német projektje, pedig elsősorban orosz és brit ellenkezést váltott ki. Mindkettő az érintett térségben az infrastruktúrát építő birodalom politikai, gazdasági, katonai érdekeit szolgálta, befolyását növelte volna, vagy legalábbis a versenytársak percepciója ez volt.

A hidegháború alatt az ideológiai, katonai stb. ellentétek jelentôsebbek és látványosabbak voltak, ugyanakkor a két szuperhatalom az infrastruktúra fejlesztését is alkalmazta a befolyása növelésére. A bipoláris világrendet követően az egymással versengő hatalmak területi érdekeinek kérdése háttérbe szorult, a 2000-es évekkel kezdődően azonban több szereplő érdekérvényesítési képessége is megváltozott. Ennek következtében egyes földrajzi térségekben ismét befolyási övezetek kezdtek kirajzolódni, ahol az infrastruktúrafejlesztés újra a befolyás növelésének eszközévé vált. Ilyen többek között Kína kelet-afrikai aktivitása, vagy Oroszország közép-ázsiai, kaukázusi és kelet-európai csővezetékes projektjei. A nemzetközi szereplők időnként azonos térségre fókuszálnak, ami versengéshez vezethet, mint jelenleg a Balkán-félszigeten is.

\section{Miért pont a Nyugat-Balkán?}

A Balkán-félsziget geopolitikai jelentősége a különböző korszakokban változóan ugyan, de mindig is létezett, melynek alapja relatív helyzete, az EU és a Közel-Kelet, valamint a Fekete- és a Földközi-tenger medencéi között, a tengeri és szárazföldi stratégiai jelentő- 
ségú útvonalak mentén. Ahogy ERDősı F. (2005, p. 17.) oly plasztikusan megfogalmazta, a térség ,...közlekedési értékének felkiáltójeles paradoxona a geopolitikai/közlekedésföldrajzi szempontból szuperexponált fekvés és az átjárhatóságot nehezítő természeti adottságok közötti feszültség, melynek feloldására [...] külső hatalmi erök voltak képesek az ókortól kezdve létesített, híressé vált közlekedési vonalak kierôszakolásával." Azaz a térség, fekvéséből fakadóan, mindig is jelentőséggel bírt, de a közlekedési helyzet kiaknázására többnyire csak birodalmak voltak képesek.

Emellett a Balkán kiválóan alkalmas a különböző hatalmak befolyásának kiépítésére is. Ennek egyik eleme az államföldrajzi fragmentáltság (REMÉNYI P. 2019). A Balkánnak a nemzetté válásban megkésett, függetlenségét későn megszerzó államalakulatai és nemzetei számára állam- és nemzetépítésükhöz szükségük volt/van külső támogatásra. A térség államai amellett, hogy alapvetően kis államok, Európa legelmaradottabbjai közé is tartoznak (1.táblázat), ahol az elhúzódó tranzíciós folyamatok következtében ma sem mindenhol zökkenőmentes a társadalmi-politikai-gazdasági intézmények múködése, magas a munkanélküliség, jelentős a korrupció. Ez mind megkönnyítheti, olcsóbbá teheti a külső szereplők helyi projektjeit, mindamellett, hogy kockázati faktorokat is hordoznak magukban (megtérülés, konfliktusok kiújulása).

1. táblázat-Table 1

A térség államainak néhány fontos gazdasági mutatója

Some important economic indicators of the countries of the region

\begin{tabular}{|c|c|c|c|c|}
\hline ország & $\begin{array}{c}\text { kereskedelmi } \\
\text { egyenleg } \\
\text { (2019; millió € })\end{array}$ & $\begin{array}{c}\text { GDP/fó } \\
(2018 ; €)\end{array}$ & $\begin{array}{c}\text { munkanélküliség } \\
\text { (2018; 20-64 év } \\
\text { közöttiek, \%) }\end{array}$ & $\begin{array}{c}\text { fiatalkorú } \\
\text { munkanélküliség } \\
\text { (2018; 15-24 év } \\
\text { közöttiek, \%) }\end{array}$ \\
\hline Montenegró & -2185 & 7490 & 15,2 & 29,4 \\
\hline $\begin{array}{l}\text { Észak- } \\
\text { Macedónia }\end{array}$ & -2039 & 5150 & 20,7 & 45,4 \\
\hline Albánia & -2843 & 4460 & 12,3 & 28,3 \\
\hline Szerbia & -5359 & 6140 & 12,8 & 29,7 \\
\hline $\begin{array}{l}\text { Bosznia } \\
\text {-Hercegovina }\end{array}$ & -4093 & $4580 *$ & 18,5 & 38,8 \\
\hline Koszovó & -3114 & 3740 & 29,4 & 55,4 \\
\hline$E U-27$ & - & 30160 & 7,3 & 16,1 \\
\hline
\end{tabular}

*2017-es érték

Forrás/Source: Eurostat (2017-2019)

Számos külső szereplő számára jelent különböző szempontból fontos területet a Balkán. Az Európai Unió számára ez a „hátsó udvar”, ahol már az 1990-es évek konfliktusaiban sem tudott egyedül rendet teremteni. A szervezett bűnözés, az illegális áramlások egy része ebből az irányból éri el a közösséget ezért biztonságpolitikai jelentősége nagy, az európai centrum országai számára gazdasági érdekeket is megtestesít. Emiatt a NyugatBalkán stabilitása és prosperitása összeurópai érdek (EC 2018a).

Oroszország számára egyrészt továbbra is kapcsolati tér, másrészt az EU befolyásolási terepe. A hagyományos faktorok, mint a Fekete-tenger kijárata, a Közel-Kelet és a Mediterráneum közelsége, valamint az EU szomszédsága (melynek leggyengébb láncszemei 
a délkelet-európai tagok - BECHEv, D. 2017) mind vonzóvá teszik, Dugin koncepciójában a térség nagy része Oroszország érdekszférája (idézi SzILÁGYi I. 2019, p. 28). Az energiaszállításokban ez Ukrajna megkerülésének egyik lehetséges útvonala. Kína megközelítésében a kapcsolati jelleg dominál: a Balkán elsősorban, mint a kínai globális projekt, az Övezet és Út (BRI) egyik utolsó, EU előtti állomása jelenik meg. Törökország esetében leginkább az A. DAVUTOĞLU (2016) által megfogalmazott szomszédságpolitika és a neo-oszmanizmus a kulcs. Ebben a tekintetben inkább az EU-hoz hasonló a viszonyulás, amennyiben a Balkán a közelkülföld, inkább cél, mint eszköz, de egyben Törökország és az EU közti kapcsolati tér is. Az Egyesült Államok Balkán-politikája az elmúlt évtizedekben inkább követő jellegú, fő céljai általánosak: stabilitás, prosperitás. A globális versenytársak megjelenése azonban aktívabb szerepvállalást okoz, melyben az ellensúlyozás dominál.

\section{Nagyhatalmi érdekek a Nyugat-Balkánon - a közlekedés}

A nagyhatalmi érdekek a Balkánon számos területen keresztezik egymást és többféle módon igyekeznek azokat érvényesíteni. Ezek egyike a jelentős földrajzi vonatkozású közlekedési/szállítási makro-infrastruktúra fejlesztése. A Balkánon e közlekedési hálózatok természeti és társadalmi okokból kifolyólag is gyenge kiépítettségűek, az államok pénzügyi lehetôségei korlátozottak (ERDősı F. 2005), emiatt a nagyrendszerek sokszor külső forrásból épülnek, így sohasem teljesen érdeksemlegesek. Ez történetileg sem térségidegen jelenség, a félszigeten, a 19. századi vasútépítési korszakban számos hatalomnak volt térségre vonatkozó fejlesztési koncepciója: Nagy-Britanniának Közép-Európából Isztambul (Boszporusz), majd Szaloniki (Szuez) felé, az Osztrák-Magyar Monarchiának Oroszország felé a Balkán északi részén, az Oszmán birodalomnak északnyugat felé Bosznia irányába. (ERdősi F. 2005, ERdősı F.-Komlós A. 2001). A jelenlegi helyzettel párhuzamot mutat, hogy a balkáni országok akkor is támogatták, hogy kiépüljenek a vasúti összeköttetések, ha a pénzügyi fedezetük nem volt meg hozzá. A külföldi tökéből épülő vonalak építését és finanszírozását pedig akkor is és ma is korrupciós botrányok kísérték (JELAVICH, B. 1996, pp. 24-25). Napjainkban az eltérő érdekek által vezérelt közlekedési fejlesztések újra jellemzői a Balkánnak

\section{Európai Unió}

Az EU az infrastruktúrafejlesztés támogatását évtizedek óta alkalmazza az unión belüli és a csatlakozásra váró országok és a tagok közti kohézió erősítésére. A TEN (TransEuropean Network) és a Pán-Európai (Helsinki) korridorokat egyaránt a 90-es években jelölték ki és az utóbbiak kimondottan a kelet-közép-európai (bennük a balkáni) térség modernizálandó hálózatainak gerincét jelölik. A rendszert 1995-től tovább bóvítették (Transport Infrastructure Needs Assessment - TINA), elsősorban helyi igények alapján (FLEISCHER T. 2007).

Az EU pénzügyi eszközökkel is hozzájárul a térség infrastruktúra-fejlesztéséhez. Számos uniós kezdeményezésű, regionális léptékú fejlesztési stratégia is készült a térséggel kapcsolatban (Transport Infrastructure Regional Study in the Balkans [TIRS] - LOUIS BERGER SA 2002, Regional Balkans Infrastructure Study [REBIS] - EC 2003), melyek projektszinten is megvizsgálták a lehetséges fejlesztési irányokat, javaslatokat tettek, prioritizáltak, ugyanakkor a fejlesztések közül számos mind a mai napig nem készült el (pl. V/C, vagy a Szarajevó-Podgorica útvonal - E762). Több nagyberuházás azonban napjainkra ért révbe, úgy mint a szerbiai autópályák (X. korridor, A1 és A4), melyek elérték az államhatárt, 
vagy a horvátországi autópályák többsége. Ezek jelentős részben uniós támogatásból és hitelból épültek meg és további projektek (pl. Niš-Pristina autópálya szerb szakasza vagy éppen a V/C korridor boszniai szakaszai) is a megvalósítás különbözó fázisában vannak.

Ugyanakkor az EU belső válsága a térséggel kapcsolatos aktivitását is háttérbe szorította, mely helyet engedett új szereplők megjelenésének, akik az infrastruktúra-fejlesztés területén is aktívak. Fontos leszögezni, hogy ezeket a fejlesztéseket nem lehet automatikusan károsnak, vagy haszontalannak nevezni, de figyelembe kell venni az esetleg nem kívánt „mellékhatásokat” (korrupció, eladósodás, növekvő befolyás), melyek nem minden esetben állnak összhangban az EU törekvéseivel.

Részben a kínai fejlesztések számbeli, értékbeli és stratégiai irányokat is lefedő növekedése, valamint a többi szereplő (elsősorban Oroszország) növekvő befolyása és általában az integráció megakadásának következtében az EU is felismerte a helyzet jelentóségét és a tagállamok egy csoportja német vezetéssel új lendületet kívánt adni a térség integrálásának, elindítva 2014-ben az ú.n. Berlini folyamatot. A folyamat támogatására hirdették meg a Connectivity Agenda-t (összekapcsolási tervet), mely a közlekedési infrastruktúra fejlesztését is célul túzte ki. Az uniós támogatású és (társ)finanszírozású infrastruktúrafejlesztés növekedésnek indult, többek között a boszniai V/C korridor mentén, illetve kimondottan országok közötti kapcsolatok erősítése céljával. A folyamat csúcstalálkozóin (Bécs, Párizs, Trieszt, Szófia, Poznan) az infrastruktúra fejlesztések újabb és újabb elemei kerültek napirendre (EC 2017, EC 2018b), melyek a nyugat-balkáni közlekedés gerinchálózatát alkotó közlekedési folyosókhoz kapcsolódnak (1.ábra).

Az EU az 1990-es évektől kezdve több mint 11 milliárd euró értékben biztosított támogatást (Európai Bizottság) és kölcsönöket (Európai Beruházási Bank) a nyugat-balkáni államok részére az energetikai és közlekedési infrastruktúrában megvalósuló projektek számára, amelyek további 22 milliárd euró értékű beruházás megvalósítását tették lehetővé. A fent említett Connectivity Agenda keretein belül 2015 és 2020 között 1 milliárd euró támogatást különítettek el ezeknek a projekteknek a megvalósításához, amelyek keretében többek között 320 km-nyi vasúti pálya, 170 km-nyi autópálya, illetve két határátkelő híd építése, illetve felújítás is szerepel. A támogatásokhoz ebben az időszakban további 3 milliárd eurónyi kölcsön is társult az EU-s partner intézményektől és a fejlesztések 45 ezer embernek létesítettek új munkahelyet a térségben. A beruházások következtében a vasúti menetidő két órával csökkent Belgrád és Szófia, illetve Belgrád és Bar között, mindamellett, hogy Pristinából is egy órával hamarabb el lehet már jutni Szófiába. A jelenleg legelőrehaladottabb stádiumban lévő támogatott projektek közé tartozik a 100 millió eurós beruházási összeget is meghaladó Svilaj-híd megépítése a Száva fölött, amely Boszniát és Horvátországot köti össze, de épül Zenicától északra új alagút is, mindkettő az V/C korridor részeként. Ugyancsak megkezdődtek már a munkálatok az „Orient/East-Med Corridor” több vasúti szakaszán, így a Montenegrót és Szerbiát összekötő R4-es útvonal, illetve a Koszovót és Macedóniát összekötő R 10-es nyomvonal mentén is (EC 2019 p. 16-17.).

A vízi közlekedés infrastruktúrájának fejlesztése is alapvetően az EU-hoz kötődik, kivéve néhány kulcsfontosságú tengeri kikötőt (pl. Pireusz vagy Bar), ahol a kínai érdekek a meghatározók. A horvátországi kikötők nagyrészt uniós forrásokból újultak (Dubrovnik, Zadar) és újulnak (Split) meg. Ugyanakkor nagyhatalmi versengés képe rajzolódik ki Rijeka új konténerkikötőjének a tervezett megépítésén. A megközelítőleg 20,5 milliárd kuna értékű projekt elnyerésére ugyanis jó esélyei voltak egy kínai cégekből álló konzorciumnak. A sajtóhírek alapján azonban 2021 elején nagyban köszönhetően az amerikai és EU-s nyomásnak érvénytelenítették a közbeszerzést (Simmonds, L. 2021). Szerbia új dunai kikötőjének létesítését Belgrádban szintén az EU támogatja. A kikötő csatlakozna a megújuló Belgrád-Budapest vasútvonalhoz, illetve fontos közúti vonalakhoz is (E-70,E-7). 


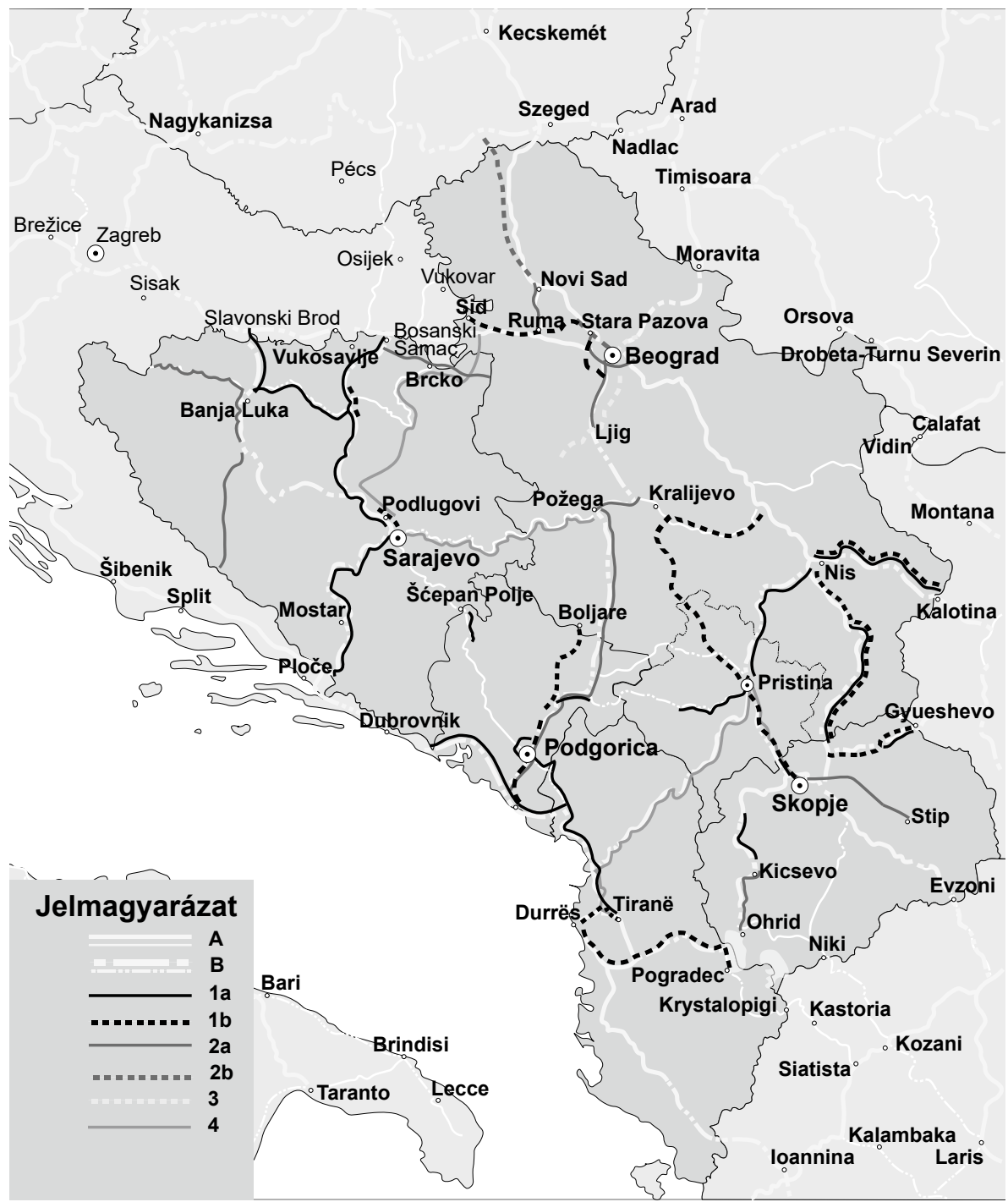

1. ábra A nyugat-balkáni gerinchálózat és a jelentősebb közlekedési infrastruktúra-fejlesztési projektek

Figure 1 The core network in the Western Balkans and the major transportation development projects.

Jelmagyarázat: A: Törzs- és átfogó közúthálózat - befejezett, B: Törzs- és átfogó közúthálózat - tervezés/fejlesztés alatt, 1a: Európai Uniós érdekeltségű közútfejleszté,s 1b: Európai Uniós érdekeltségű vasútfejlesztés,

2a: Kínai érdekeltségú közútfejlesztés, 2b: Kínai érdekeltségú vasútfejlesztés, 3: Orosz érdekeltségú vasútfejlesztés, 4: Török érdekeltségú közútfejlesztés.

Legend: A: Core and comprehensive road network completed, B: Core and comprehensive road network under planning/ construction, 1a: EU road projects, 1b: EU rail projects,

2a: Chinese road projects, 2b: Chinese rail projects, 3: Russian rail projects, 4: Turkish road projects.

Forrás: EB (2016), valamint saját gyújtés alapján szerkesztette: Reményi Péter, Csapó Dániel Gábor és Csapó-Kádár Tünde Source: Edited by Reményi Péter, Csapó Dániel Gábor and Csapó-Kádár Tünde based on EB (2016) and own collection

Az EU új „Nyugat-Balkán stratégiája” (EC 2018a), szintén zászlóshajó-elemmé emelte az infrastruktúra-fejlesztéseket is magában foglaló, az összekapcsoltságot erôsítő (Increasing connectivity) irányt, kiemelve gazdasági és biztonsági jelentőségét is. Az Európai Bizottság 
2020 tavaszán bejelentette, hogy a vírushelyzet miatti támogatások mellett, a 2021-2027 közötti időszakban előreláthatólag az Előcsatlakozási Támogatási Eszköz III (IPA 3) keretein belül 14,5 milliárd euró összegú pénzügyi támogatás/kölcsön is lehívható lesz, amelynek kiemelt részét fogja képezni a közlekedési és energetikai összeköttetések finanszírozása.

\section{Oroszország}

A Balkánon az egyik legaktívabb nagyhatalom az elmúlt három évszázadban az orosz állam volt. Ennek az aktivitásnak a súlypontja a 19. századra tehető, míg a két világháború közti szovjet állam térségbeli szerepvállalása alacsony volt, a hidegháború időszakában azonban az érdekszféra-politika következtében a félsziget ismét felértékelődött Oroszország számára és ekkor épültek meg az első, az egykori Szovjetunióból szénhidrogéneket a térségbe szállító vezetékek is. A Szovjetunió felbomlását követő, orosz szempontból viszonylag „,sikertelen" időszakot követően, a 2000-es években részben a növekvő energiaárak következtében egyre inkább megerősödő Oroszország a Balkánra is aktívan tért vissza (LuDVIG Zs. 2014).

Az aktuális orosz külpolitikai koncepció (Foreign Policy Concept... 2016) nem említi a Balkánt, szemben az előző, 2013-as koncepcióval (Foreign Policy Concept... 2013), mely csak egy bekezdésben érinti, de kiemeli, hogy Oroszország számára nagy stratégiai jelentőséggel bír, többek között közlekedési és szénhidrogén-szállítási csomópontként. Oroszország a gyakorlatban a külpolitikai érdekérvényesítés széles tárházát alkalmazza a térségben: gazdasági eszközök, média befolyás, titkosszolgálati akciók, baráti rezsimek támogatása, kulturális intézmények stb. mind részét képezik Moszkva befolyása növelésének (bővebben lásd pl.: BECHEV, D. 2017).

Az orosz érdekek mentén történő infrastruktúra-fejlesztéseknek az ezredfordulót követően két jól körülhatárolható területét figyelhetjük meg. Az egyik a szerbiai vasútfejlesztések köre (pl.: Belgrád-Pancsova, Újvidék-Stara Pazova, Niš-Preševo), a másik pedig a közlekedési infrastruktúra egy nagyon speciális szegmense: a csővezetékes szállítás. Geopolitikai szempontból jelentősebb az utóbbi, amely napjainkig számos, eltérő érdekek mentén versengő projektet eredményezett (Kocsis K.-TINER T. 2009). Ez természetesen nem idegen az orosz külpolitikától és könnyen érthető, ha figyelembe vesszük az Oroszország rendelkezésére álló szénhidrogén-készleteket és a térség, valamint Európa többi része energiaéhségét.

A hivatalosan 2007-ben indult Déli Áramlat projekt az orosz vezetésű energetikai beruházások zászlóshajója volt a térségben. Önmagában kialakult egy kisebbfajta verseny, hogy mely országokat érintheti majd a csővezeték, a megvalósulás esetén pedig az orosz gáztól és annak politikai célú árváltoztatási lehetôségétől is az orosz politikai befolyás növekedését várhattuk. Az ellentétes geopolitikai érdekek azonban odáig vezettek, hogy amerikai majd európai ellenállást követően az orosz vezetésú projekt többszöri újratervezés után sem tudott megvalósulni, 2014-ben hivatalosan is leállt. Infrastrukturális téren így - leszámítva a Déli Áramlat Lite/Balkan Stream vezetékrendszert (CoHEN, G. 2019), melyből 2021. január 1-re a szerbiai szakasz is elkészült - Oroszország aktivitása a szerbiai vasútfejlesztésekre korlátozódik.

Az energetikai infrastruktúra területén is világosan látszik, hogy, bár egyes balkáni országok nagymértékben ki vannak szolgáltatva az orosz energiahordozóknak, a teljes orosz exportban az abszolút súlyuk nem jelentôs, ezáltal a térség az orosz érdekek érvényesítésének sokkal inkább eszköze (tranzitútvonal) mint tétje (2. táblázat). A Gazprom által 2017-ben a Nyugat-Balkán országaiba exportált gáz az összes export kevesebb, mint 2\%-át jelentette, és a Magyarországra szállított gáz volumenének is csak 79\%-át érte el (Gazprom in figures 2013-2017). Az energetikai kiszolgáltatottság - melynek csökkentésére komoly, az EU által támogatott projektek is zajlanak (pl.: Déli Gázfolyosó, Eastring, 
Földgázfogyasztás és import 2017

Natural gas consumption and import 2017

\begin{tabular}{lccc}
\hline Ország & fogyasztás & orosz import & Arány \\
\hline Bosznia-Hercegovina & 0,2 & 0,2 & 100 \\
Horvátország & 2,6 & 2,8 & 100 \\
Észak-Macedónia & 0,2 & 0,3 & 100 \\
Szerbia & 2,7 & 2,2 & 81 \\
Összesen & 5,7 & 5,5 & 96 \\
\hline
\end{tabular}

Forrás/Source: Gazprom in figures 2013-2017, CIA World Factbook

LNG terminálok) - közvetve komoly eszközt ad Oroszország kezébe, hogy a térség politikai, gazdasági és társadalmi folyamatait befolyásolja érdekeit érvényesítse (bővebben lásd pl.: BECHEV D. 2017; CSD 2018).

Az orosz energia fó felhasználói azonban Nyugat-Európában találhatók és a balkáni szállítási vonalak a „problémás” tranzitországok (Ukrajna, Belarusz) elkerülésére és az útvonalak diverzifikálására szolgálhatnának (KocSIs K.-TINER T. 2009), a megvalósuló vezetékek azonban csak hazánkig tartanak.

Részben a geopolitikai ellentétek miatt a térség továbbra sem tudja betölteni energetikai tranzit szerepét, az érdekek kioltják egymást, a versengő tervek sokszor nem valósulnak meg (pl.: Déli Áramlat és Nabucco). Ugyanakkor az EU egyik fontos projektje, a Déli Gázfolyosó révbe érni látszik, november közepén megérkezett az első kereskedelmi szállítmány Olaszországba, de ez a projekt a Nyugat-Balkán nagy részét elkerüli, csak Albániát érinti (2. ábra), habár a balkáni leágazások tervei léteznek.

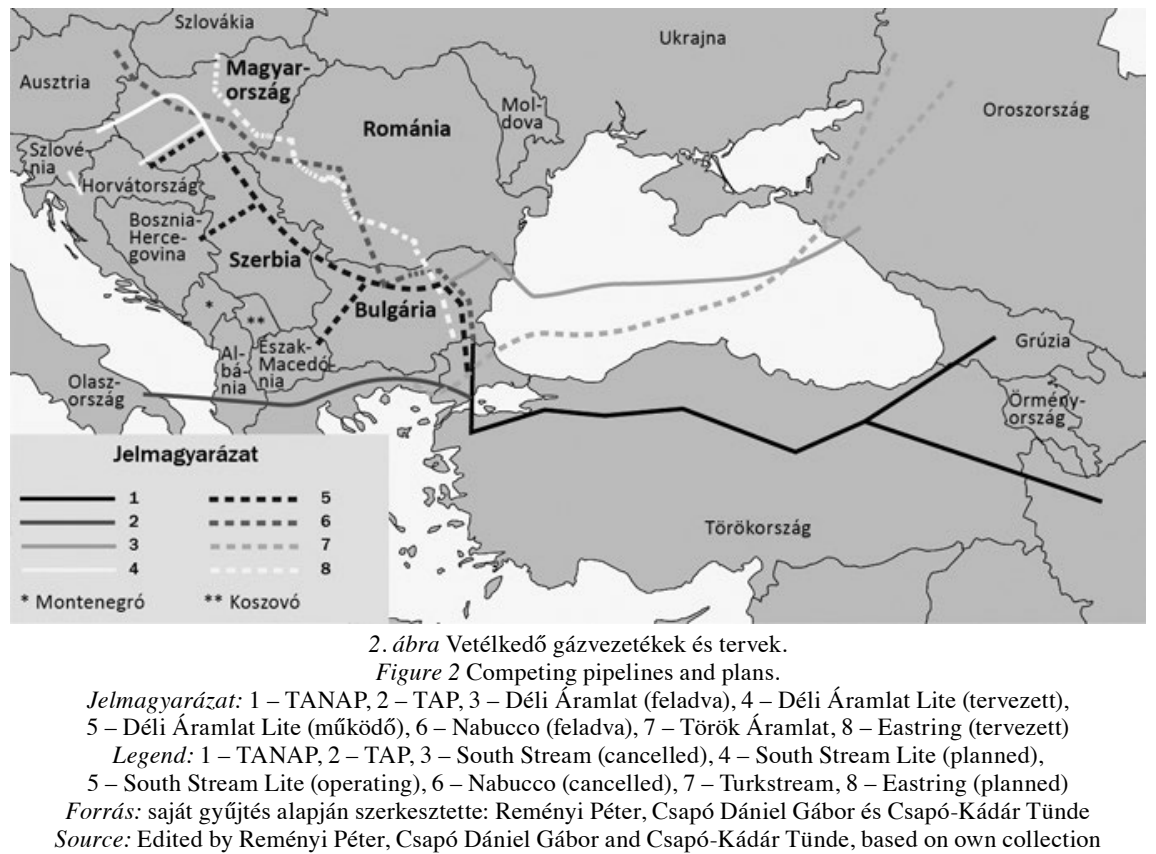


Kína az európai érdeklődés lanyhulásával és a kínai külföldi beruházási projektek egy rendszerbe szerveződésével párhuzamosan új szereplőként érkezett a térségbe. A nyugat-balkáni országok és Kína közötti kapcsolatok intenzitásának a növekedése leginkább az ázsiai ország nyitásának köszönhetô. A nyugat-balkáni országok részei a kínai Övezet és Út Kezdeményezésnek, amely Hszi Csin-ping megfogalmazásában „elösegíti az abban rész vállaló nemezeteknek a közös érdekeken,feleloosségvállaláson és jövón alapuló közösség megteremtését” (JINPING, X. 2019 p. 147.). A kínai elnök 2013-ban Astanában elmondott beszédével tette le a vízió szimbolikus alapkövét. A kínai vállalatok és pénzügyi intézmények térnyerése ugyanakkor már előbb megkezdődött (pl. Pireusz kikötője már 2009 óta kínai koncesszióban van) és 1999-ben a „go out” policy is hasonló célokat irányzott elő, mint az új selyemút (SALÁt G. 2019).

A projektek egy része Kína és az EU közti kapcsolatok erősítését szolgálja (pl. a Pireuszi kikötőtől Magyarország felé irányuló vasútfejlesztési projektek, a montenegrói Bar kikötôje és Belgrád közti autópálya-fejlesztések stb.). Emellett olyan projekteket is finanszíroz, melyeket az EU nem tud, vagy nem akar. Ezek sok esetben nem állnak összhangban az EU céljaival, akár a közlekedési korridorok tekintetében, akár fenntarthatósági megfontolásokból. Montenegró autópálya-fejlesztésénél a rendkívüli méretű eladósodás jelenthet veszélyt (HoPKINS, V.-KYNGE, J. 2019), amellett, hogy a reláció mind a TIRS, mind a REBIS stratégiában a központi hálózat része. Macedóniában az infrastruktúra fejlesztéséhez kapcsolódó korrupció lett felkapott ügy, a belpolitikai változások pedig egyelőre a fejlesztések felfüggesztéséhez vezettek (MAKOCKI, M.-Nechev, Z. 2017). A Boszniai Szerb Köztársaság esetében pedig az európai fejlesztési pályákkal nem kompatibilis irányokat is finanszírozza Kína, melyek akár egy szakadár állam gerinchálózatát is alkothatják és helyenként etnopolitikai elveket is követnek (1.ábra) (REMÉNYI P. et al. 2016).

A BRI megítélése emiatt is ellentmondásos, a kritikusok/ellenzők élén az Amerikai Egyesült Államok áll, amelynek a 2017-ben kiadott nemzetbiztonsági stratégiájában Kínát (Oroszországgal egyetemben) már olyan országokként határozza meg, amelyek olyan világrend kialakításán munkálkodnak, amely az értékek és érdekek szintjén is ellentétes az amerikaival (CSIKI VARGA T. 2018). 2020 májusában egy, a Fehér Ház által publikált jelentés kifejti, hogy Kínának mely tevékenységeit határozza meg az USA ellenségesnek és, hogy ezekkel szemben milyen ellenlépéseket tett, illetve szándékozik meglépni (White House 2020). A dokumentum leszögezi, hogy Peking a külföldön megvalósuló beruházásait arra használja, hogy kiterjessze a politikai és katonai befolyását, illetve, hogy a legfontosabb technológiai szektorokban a kínai ipari sztenderdek terjedjenek el. Az amerikai fél szerint a BRI keretein belül megvalósuló beruházások jellemzően rossz minőségúek, korrupcióval és környezetszennyezéssel járnak, mindamellett, hogy a projektekből kizárják a helyi közösségeket és eladósítják az államokat. Ugyan egyes stratégiai dokumentumokban az EU is felhívja a figyelmet a kínai beruházok kapcsán felmerülő visszásságokra, viszont (nagyrészt a közös külpolitika hiánya miatt) sokkal kevésbé elítélő hangot üt meg, mint az Egyesült Államok.

Jellemző az Európai Unió BRI-hez való viszonyulására, hogy egy, az Európai Bizottság által 2019-ben megjelentetett stratégiai dokumentum egyrészt elismeri, hogy Kína hozzájárult a nyugat-balkáni országok gazdasági növekedéséhez, másrészt viszont kiemeli, hogy a beruházások alkalmával a kínai fél sok esetben nem veszi figyelembe a szocioökonómiai aspektusokat, illetve a fenntartható finanszírozás követelményét, ami a fejlődő országok eladósodásához, illetve ahhoz vezethet, hogy Kína stratégiai jelentôségú erooforrásokhoz/ vagyontárgyakhoz jut hozzá (EC 2018c). 
Ugyan a nyugat-balkáni országoknak még mindig az Európai Unió a legjelentősebb kereskedelmi partnerük, Kína is egyre fontosabb szerepet tölt be az esetükben (3. táblázat). Az Eurostat adatai alapján 2019-ben az EU a térség exportjának 68\%-áért, míg importjának $61 \%$-áért felelt, Kína pedig a nyugat-balkáni országok importjának a 10\%-áért felelt (EUROSTAT 2020).

3. táblázat - Table 3

A nyugat-balkáni országok legjelentősebb kereskedelmi partnerei, 2019 (\%)

The major trade partners of the Western Balkan countries, $2019(\%)$

\begin{tabular}{lcc}
\hline ország & export & import \\
\hline EU27 & 68 & 61 \\
Többi Nyugat-balkáni ország & 20 & 10 \\
Oroszország & 4 & 6 \\
Kína & 2 & 10 \\
Törökország & 2 & 7 \\
Egyéb & 3 & 6 \\
\hline
\end{tabular}

Forrás/Source: Eurostat, 2019

Kína térségbeli aktivitása hosszú távon a gazdasági befolyást követően politikai befolyást is eredményezhet, melynek első jelei már látszanak. Az EU és az EU-ba igyekvő államok számára egyik ,járulékos” hatás sem kellemes, Kína nézőpontjából viszont természetes stratégia az egyik versenytárs által magára hagyott térségben befolyást építeni, különösen, ha az a térség az említett versenytárs félperifériája.

\section{Törökország}

Törökország és a Balkán kapcsolata a fél évezredes „,közös történelem” fényében vizsgálandó. Az egykori hódító birodalommal szemben a 19. és 20. században sikeres nemzeti felszabadító mozgalmak bontakoztak ki és a térség nemzetállamait eredményezték. Az atatürki reformok az egykori birodalmi területekkel pragmatikus viszonyokat alakítottak ki, a balkáni országok irányába a kapcsolatok lazák voltak. A délszláv háborúkkal párhuzamosan nőtt a török érdeklődés a térség irányában, az igazi változást azonban a 2000-es évek hozták, amikor megjelent a mai vezető kormánypárt (AKP), hatalomra került a meghatározó politikus (Erdoğan) és megszületett A. Davutoğlunak (2001, magyarul 2016) az állam külpolitikájának alapjait újradefiniáló munkája (EGERESI Z. 2013; FEKETE J. 2014).

Davutoğlu doktrínája értelmében Törökország külpolitikájában a földrajzi közelségnek, a történelmi örökségnek és a muszlim közösségeknek egyaránt szerepe van a gazdasági érdekek mellett (FEKETE J. 2014; DAVUTOĞLU, A. 2016; LeCHNER Z. 2019). Így nem véletlen, hogy a Balkánra az új török külpolitika aktívan tért vissza, hiszen a térségben a doktrína minden eleme teljesül. Törökország azonban nem versenyezhet az EU-val vagy Kínával pénzügyi-gazdasági téren, sem Oroszországgal energetikai vagy világpolitikai súlyát illetôen. Ez is nyilvánvalóan hozzájárul ahhoz, hogy a térségbeli török jelenlét jól körülhatárolható szektorokban figyelhető meg. A szolgáltató szektor egyes területei mellett ilyenek az oktatás, a kultúra, az örökségvédelem, vagy a vallási szféra, melyek közös vonása, hogy szimbolikus jelentôségük lényegesen nagyobb, mint reálgazdasági vagy reálpolitikai súlyuk. 
A közlekedési infrastruktúra tekintetében a szimbolikus olvasattal is rendelkező projektek támogatása szintén jellemzője a török politikának. A Pristina-Tirana autópályának (LikMeTA, B. et al. 2014), melyet Patriotic highway-nek is neveznek, mert összeköti az albániai és a koszovói albán központokat az egyik legnagyobb kivitelezője a török ENKA holding volt (az amerikai Bechtel vállalattal konzorciumban), csakúgy, mint a Pristina és az észak-macedón határ (Hani i Elezit) és azon túl Skopje közti autópályáé (BEGISHOLLI, B. 2019), mely országban a harmadik legnépesebb balkáni albán közösség él (1. ábra). A projektek illeszkednek a térség gerinchálózatához, de mindkettôt komoly korrupciós vádakkal is illették.

Szintén Törökország a legnagyobb nemzetközi politikai támogatója a Belgrád és Szarajevó közti kettős autópályának, melynek a nyomvonalairól csak a török elnök közbenjárása után, 2019-ben született megegyezés. A találkozón Erdoğan által a Béke autópályájának nevezett útvonal a tervek szerint észak és kelet felől is eléri Szarajevót Belgrád irányából (DAILY SABAH 2019). Az északi ágon a szerbiai szakaszok már építés alatt állnak, a finanszírozó a török Exim Bank, a fő kivitelező a török Tasyapi vállalat (RALEV, R. 2020; LAKIC, M.-ZIVANOVIC, M. 2019), a keleti irány viszont egybeesik az uniós TEN-T hálózat nyugat-balkáni prioritásaival.

A fenti beruházások gazdasági és szimbolikus jelentőségükön túl beleillenek a Davutoğlu-féle stratégiába is, mely a térségbeli török érdekek legfontosabb hordozóiként a (muszlim) bosnyákokat és albánokat nevezi meg (DAVUTOĞLU, A. 2016). A Balkán Törökország számára így egyszerre lesz a külpolitika célterülete (az EU-hoz hasonlóan) és kapcsolati terület (Oroszországhoz hasonlóan), ahol a közlekedési infrastruktúra-fejlesztések török támogatása érdekalapú, a „baráti” nemzetek területeire koncentrál.

\section{Egyesült Államok}

Az Egyesült Államok balkáni stratégiájában számos hangsúlyeltolódás figyelhetô meg az elmúlt évtizedekben. Sosem tartozott az amerikai érdekek érvényesítésének kiemelt fontosságú területei közé, de az 1990-es évekre a Clinton adminisztráció alatt az amerikai béketeremtés egyik fontos színterévé vált. A 2000-es évektől máshová terelődött az amerikai figyelem, Trump elnöksége alatt azonban ismét előtérbe került a Balkán, nem függetlenül az amerikai „versenytársak” térségbeli aktivitásától.

A közlekedési infrastruktúra kérdése az USA esetében is megjelenik: a de facto függetlenségét Amerikának köszönhető Koszovó legfontosabb közlekedési beruházása, a Pristinát Tiranával és a tengerrel összekötő autópálya török-amerikai támogatással valósult meg, mely civil jelentősége mellett a térség legnagyobb amerikai katonai támaszpontja (Camp Bondsteel, Koszovó) számára is fontos.

Az újra növekvő amerikai figyelmet az energetikai infrastruktúra orosz fejlesztési elképzelései váltották ki és kezdetben ennek ellensúlyozására irányult (lásd Déli áramlat). 2020-ban aztán a szerb-koszovói tárgyalások során amerikai kezdeményezésre számos közlekedési projekt is újra előtérbe került. Ezek általában a Belgrád, Pristina és az Adria közti kapcsolatokat igyekeznek fejleszteni. 2020 februárban a Belgrád és Pristina közti vasúti kapcsolatok újraindításáról, valamint a Pristina-Merdare-Niš autópálya (Peace Highway) megépítéséről is szándéknyilatkozat született (RADIO FREE EUROPE 2020). Az autópálya, mely része az EU terveinek is és egyes részei már építés alatt is állnak, Pristinától a korábban említett autópályában folytatódik Tirana és az Adria irányába, míg Nišnél a X. Páneurópai korridorhoz csatlakozik, tulajdonképpen az egykori Lissus-út nyomvonala ez (HÉzSER A. 1916). 
A szeptemberi washingtoni egyezmény megerősíti a fenti megállapodásokat, valamint kiegészíti egy új elemmel, az autópálya relációjában felújítandó (Niš-Pristina) és kiépítendő (Pristina-Adria) vasútvonallal. Az előbbi szintén szerepel az EU dokumentumaiban, igaz csak kiegészítő irány, az Adriáig való meghosszabbítása viszont új infrastrukturális elem. (The PRESIDENT... 2020) A civil jelentőség mellett ismét ki kell emelnünk a stratégiai/katonai szempontot, mely amellett, hogy a koszovói amerikai pozíciók elérhetőségét növeli, a kínai beruházások számára teremt versenytársat, valamint a tervezett észak-déli irányú via Carpathia felé is kapcsolatot teremt. Mindezekhez a tervezett beruházásokhoz az Egyesült Államok hajlandó forrásokat is rendelni az egyezmény értelmében.

\section{Összefoglalás}

A Balkán-félsziget Eurázsia viszonylatában közlekedési szempontból stratégiai helyzetű, emiatt a világgazdaság jelentős szállítási igénye geopolitikai értelemben is növeli a térség súlyát a nemzetközi kapcsolatokban. Nagy-és középhatalmi központokhoz viszonyított elhelyezkedése és kapcsolati jellege miatt történelmi léptékben is színtere a hatalmi versengéseknek.

Napjainkban a Nyugat-Balkán Európa egyik utolsó instabil térsége, etnikai, politikai, territoriális konfliktusok terhelik a kisállamok egymás közti kapcsolatait. A „,nem térségidegen" helyzet az átalakuló világrenddel párban kiváló terepet biztosít a külső befolyások megjelenésének. Ennek egyik földrajzilag is vizsgálható eleme a közlekedési infrastruktúra fejlesztésének kérdése, mely területen a jelenlévő szereplők érdekei sok esetben metszik egymást. Az Európai Unió, Kína, Törökország, az Egyesült Államok és Oroszország egyaránt rendelkezik különböző státuszú, különböző részletességú tervekkel a térségbeli fejlesztései vonatkozásában, mely fejlesztések geopolitikai érdekeiket is szolgálják.

Az orosz-európai/amerikai energetikai infrastruktúra vetélkedésból jelenleg az utóbbi látszik győztesként kijönni, amennyiben az orosz érdekeket szolgáló vezetéktervek nem tudnak megvalósulni, míg az EU Déli Gázfolyosója megkezdte múködését. Ezt tükrözi a Balkán kikerülése a legújabb orosz külpolitikai stratégiából is. A vizsgált térség számára ennek a geopolitikai vetélkedésnek azonban kedvezőtlen mellékhatása is van, hiszen Albániát leszámítva a jelentős tranzitvezetékek egyelőre elkerülik a Nyugat-Balkánt.

Az európai-kínai ,,versenyben” jelenleg az EU igyekszik a növekvő kínai beruházásokkal lépést tartani, az EU új Nyugat-Balkán stratégiájának egyik kiemelt szegmense a (közlekedési) infrastruktúra kérdése, ugyanakkor pusztán az infrastruktúra felől tekintve a két entitás fejlesztési elképzelései nem összeegyeztethetetlenek. A Kína és az EU közti szállítás gyorsítása utóbbi érdeke is, ráadásul ez megvalósítható az EU számára is prioritást jelentő pályákon. A problémát Kína kapcsán mindenekelőtt a járulékos következmények jelentik (korrupció, kínai sztenderdek, eladósodás...).

Törökország számára, a külpolitikája egyik megalapozó munkájának tekinthető Stratégiai mélységgel összhangban, elsősorban a barátinak tekintett területek közlekedésének fejlesztése látszik prioritásnak lenni: a legjelentősebb török vonatkozású projektek vagy albán területeket kapcsolnak össze, vagy albán és bosnyák városok nemzetközi, bennük Törökország irányú relációit erôsítik, ezzel segítve a balkáni-török kapcsolatok fejlődését és az érintett államok/közösségek stabilitásának növelését.

A közlekedési infrastruktúra fejlesztése így leginkább a járulékos mellékhatások (korrupció, adósság, nem kívánt befolyás) miatt jelent problémát mind a térség országainak, mind a politikai közösségnek, ahova igyekeznek. Az új pályák, a feltárt területek, a hálózat sűrúsödése valójában mindenki érdeke. 


\title{
Köszönetnyilvánítás
}

Reményi Péter munkáját az MTA Bolyai János Kutatási Ösztöndíja és az Innovációs és Technológiai Minisztérium ÚNKP-20-5 számú Új Nemzeti Kiválóság Programja támogatta.

\author{
REMÉNYI PÉTER \\ PTE TTK Földrajz és Földtudományi Intézet, Pécs \\ remko@gamma.ttk.pte.hu \\ CSAPÓ DÁNIEl GÁBOR \\ PTE Földtudományok Doktori Iskola, Pécs \\ dnyeszter@gmail.com
}

\section{IRODALOM}

Bechev, D. 2017: Rival power. Russia in Southeast Europe. Yale University Press, New Haven and London.

Begisholdi, B. 2019: Kosovo-North Macedonia Highway Opened With Fanfare. Balkan Insight https://balkaninsight.com/2019/05/29/north-macedonia-kosovo-highway-opened-with-fanfare/

Center for the Study of Democracy (CSD) 2018: Russian Economic Footprint in the Western Balkans. Corruption and State Capture Risks. CSD, Sofia. https://csd.bg/publications/publication/russian-economic-footprintin-the-western-balkans-corruption- and-state-capture-risks/

CIA World Factbook https://www.cia.gov/library/publications/the-world-factbook/fields/270.html

CoHEN, G. 2019: Natural gas import and export routes in South-East Europe and Turkey. IENE Working Paper no. 26. IENE, Athens. 63 p. https://www.iene.eu/articlefiles/working\%20paper\%20no\%2026.pdf

Concept of the Foreign Policy of the Russian Federation 2013

https://www.mid.ru/en/foreign_policy/official_documents/-/asset_publisher/CptICkB6BZ29/content/id/ 122186

Concept of the Foreign Policy of the Russian Federation 2016

https://www.mid.ru/en/foreign_policy/official_documents/-/asset_publisher/CptICkB6BZ29/content/id/ 2542248

Csiki VARga T. 2018: A Trump-stratégia nyomában - A 2017-es amerikai Nemzeti Biztonsági Stratégia értékelése. Nemzet és Biztonság 2.

Daily Sabah 2019: Construction of Sarajevo-Belgrade ,peace highway' to begin soon https://www.dailysabah.com/business/2019/07/10/construction-of-sarajevo-belgrade-peace-highway-tobegin-soon

DAVUTOĞLU, A. 2016: Stratégiai mélység: Törökország nemzetközi helyzete. Antall József Tudásközpont, Budapest.

EgERESI Z. 2013: Törökország és a Balkán. Külügyi Szemle 1. pp. 39-58.

ERDŐsI F. 2005: A Balkán közlekedésének főbb földrajzi jellemzői. Balkán Füzetek 3.,PTE TTK FI KMBTK, Pécs

ERDŐsI F. 2015: Transzeurázsiai közlekedési kapcsolatok nagy- és középhatalmi erőterekben. Tér és Társadalom 29. 2. pp. 106-126

ERDősI F.-KomLós A. 2001: Közlekedési kapcsolatok Dél-Európa félszigetei és a kontinens törzse között. Földrajzi Közlemények 125.3-4.pp. 181-203.

Erlanger, S. 2018: In a New Cold War With Russia, Balkans Become a Testing Ground. The New York Times https://www.nytimes.com/2018/04/10/world/europe/european-union-balkans.html

European Commission (EC) 2003: Regional Balkans infrastructure study - Transport. Final report. 200 p.

European Commission (EC) 2017: Connectivity agenda. Co-financing of investment projects in the Western Balkans. https://ec.europa.eu/neighbourhood-enlargement/sites/near/files/connectivity_agenda_2017_trieste_summit. pdf

European Commission (EC) 2018a: A credible enlargement perspective for and enhanced EU engagement with the Western Balkans. https://ec.europa.eu/commission/sites/beta-political/files/communication-credibleenlargement-perspective-western-balkans_en.pdf last

European Commission (EC) 2018b: Connectivity agenda. Co-financing of investment projects in the Western Balkans. https:/ec.europa.eu/neighbourhood-enlargement/sites/near/files/connectivity-agenda-2018-sofia-summit. pdf 
European Commission (EC) 2018c: EU-China - A strategic outlook. https://ec.europa.eu/commission/sites/beta-political/files/communication-eu-china-a-strategic-outlook.pdf

European Commission (EC) 2019: Connectivity Agenda for the Western Balkans. https://ec.europa.eu/neighbourhood-enlargement/sites/near/files/connectivity_agenda_brochure.pdf

European Parliament (EP) 2016: One Belt, One Road (OBOR): China's regional integration initiative (Briefing)

Európai Bizottság (EB) 2016: A Bizottság (EU) 2016/758 felhatalmazáson alapuló rendelete. https:/eur-lex.europa.eu/legal-content/HU/TXT/PDF/?uri=CELEX:32016R0758\&from=EN

Eurostat 2020: Western Balkan countries-EU - international trade in goods statistics. https://ec.europa.eu/eurostat/statistics-explained/index.php?title=Western_Balkans-EU_-_international_ trade_in_goods_statistics\#The_Western_Balkans_trade_with_the_EU_and_other_main_partners

FEKETE J. 2014: Törökország külpolitikája és kulturális jelenléte a Balkánon. In: REMÉNYI P. (szerk.): Állam- és nemzetépítés a Nyugat-Balkánon. pp. 165-184.

FLEISCHER T. 2007: Transzeurópai folyosók. A meglévők hosszabítgatása vagy egy összeurópai hálózat kialakítása? In: GLATz F. (szerk.): A Balkán és Magyarország. Váltás a külpolitikai gondolkodásban? MTA Társadalomkutató Központ, Budapest. pp. 365-380.

Gazprom in Figures 2013-2017 https://www.gazprom.com/f/posts/12/255042/gazprom-in-figures-2013-2017-en.pdf

HÉzSER A. 1916: A Balkán félsziget közlekedő útjai. Földrajzi Közlemények 44. 9. pp. 504-515.

Hopkins, V.-Kynge, J. 2019: Montenegro fears China-backed highway will put it on road to ruin. Financial Times, https://www.ft.com/content/d3d56d20-5a8d-11e9-9dde-7aedca0a081a Letöltve: 2019. 07. 07.

International Monetary Fund (IMF) 2019: Country Report No. 19/293, Montenegro. https://www.imf.org/en/Publications/CR/Issues/2019/09/09/Montenegro-2019-Article-IV-ConsultationPress-Release-Staff-Report-and-Statement-by-the-48667

Jacimovic, D-Dragutinović Mitrović, R.-Bjelić, P.-Tianping, K.-Rajkovic, M. 2018: The role of Chinese investments in the bilateral exports of new E.U. member states and Western Balkan countries. Economic Research-Ekonomska Istraživanja 31. 1.

JELAVICH, B. 1996: A Balkán története II. Osiris, Budapest

JinPING, X. 2019: The Belt and Road Initiative, Foreign Languages Press

Kaplan, R. D. 2019: A New Cold War Has Begun. Foreign Policy, január 7, 2019 https://foreignpolicy.com/2019/01/07/a-new-cold-war-has-begun/

KeMP, J. 2020: United States and China enter a new cold war. Reuters, július 22, 2020 https://www.reuters.com/article/us-global-politics-kemp-column/united-states-and-china-enter-a-new-coldwar-kemp-idUSKCN24N1MT,

Kocsis K.-Tiner T. 2009: Geopolitics of pipelines and Eastern Europe with especial regard to Hungary. Hungarian Geographical Bulletin 58. 1. pp. 49-67.

LECHNER Z. 2019: Törökország szerepvállalása a Nyugat-Balkánon. Mediterrán és Balkán Fórum 12.2.pp. 28 -53.

Likmeta, B.-Rusi, E.-Marzouk, L-ÇollakU, P. 2014: Albania-Kosovo Highway Costs Soar To 2 Billion Euros. Balkan Insight, https://balkaninsight.com/2014/04/23/albania-kosovo-highway-costs-soar-to-2-billion-euro/

LAKIC, M.-ZIVANOvic, M. 2019: Belgrade-Sarajevo Highway 'to Bring Serbia and Bosnia Closer'. Balkan Insight, https://balkaninsight.com/2019/10/08/belgrade-sarajevo-highway-to-bring-serbia-and-bosnia-closer/,

LOUIS BERGER SA 2002: Transport infrastructure regional study (TIRS) in the Balkans. Final report. 77 p.

LuDVIG Zs. 2014: Oroszország és a Balkán: érdekek és politikák. In: REMÉNYI P. (szerk.): Állam- és nemzetépítés a Nyugat-Balkánon. pp. 201-234.

MACKInder, H. J. 1904, 1999: A földrajz, mint a történelem kulcsa. In: Csizmadia S.-MolNÁR G.-PATAKI G. Zs. (szerk.): Geopolitikai szöveggyűjtemény. Stratégiai és Védelmi Kutatóintézet, Budapest. pp. 16-27.

Mahan, A. T. 1890: The Influence of Sea Power Upon History, 1660-1783. Little, Brown and Company, Boston.

Makocki, M.-Nechev, Z. 2017: Balkan corruption: the China connection. 2017/22 https://www.iss.europa.eu/sites/default/files/EUISSFiles/Alert\%2022\%20Balkans.pdf Letöltve: 2019.07.07.

Morgan Stanley 2018: Inside China's plan to create a modern Silk and Road https://www.morganstanley.com/ideas/china-belt-and-road

Munich Security Conference 2019: Munich Security Report 2019, The Great Puzzle: Who Will Pick Up the Pieces? https://securityconference.org/assets/02_Dokumente/01_Publikationen/MunichSecurityReport2019.pdf

PAP T. 2019: A ’Nyugat-Balkán' kritikai geopolitikájának térszemantikai olvasata. Közép-Európai Közlemények 12. 2. pp. $251-266$

Radio Free Europe 2020: Serbia, Kosovo Ink ,Milestone' Railway, Highway Deal. https://www.rferl.org/a/serbia-kosovo-ink-milestone-railway-highway-deal/30434249.html Letöltve: 2021. 01. 10 .

RALEV, R. 2020: Serbia to start building second section of motorway to Bosnia in 2021. SeeNews, https://seenews.com/news/serbia-to-start-building-second-section-of-motorway-to-bosnia-in-2021-688374 
REMÉNYI P. 2019: A nyugat-balkáni területi rendezés és a térség új geopolitikája. Mediterrán és Balkán Fórum 13. 3. pp. 23-38.

REMÉNYi P.-VÉGH A.-PAP N. 2016: The influence of ethnic policies on regional development and transport issues in Bosnia and Herzegovina. BELGEO - Revue Belge de Geographie 1. pp. 1-20.

SALÁT G. 2019: Hogyan értékelhető a Pekingben rendezett második Övezet és Út Fórum? Külügyi és Külgazdasági Intézet, KKI 4:1 2019/11.

https://kki.hu/2019-11-hogyan-ertekelheto-a-pekingben-rendezett-masodik-ovezet-es-ut-forum/

SimmondS, L. 2021: Rijeka Port Chinese Investment Stopped Owing to EU, US Pressure. Total Croatia News, https://www.total-croatia-news.com/business/49331-rijeka-port-chinese-investment

SZILÁGYI I. 2018: Geopolitika. PAIGEO, Budapest.

SzILÁGYI I. 2019: Az orosz geopolitikai gondolkodás. Áttekintés. Geopolitikai Szemle 1. 1. pp. 9-39.

The President of the Republic of Serbia 2020: Agreement on normalisation of economic relations signed in Washington.

https://www.predsednik.rs/en/press-center/news/agreement-on-normalisation-of-economic-relations-signed-in-washington Letöltve: 2021.01.10.

Walker, R.-Perz, S.-Arima, E.-Simmons, C. 2011: The Transamazon Highway: Past, Present, Future. In Brunn, S. D. (ed.): Engineering Earth: the Impacts of Megaengineering Projects. Springer.

White House 2020: United States Strategic Approach to the People's Republic of China. https://www.whitehouse.gov/wp-content/uploads/2020/05/U.S.-Strategic-Approach-to-The-Peoples-Republic-of-China-Report-5.24v1.pdf

WhitTlesey, D. 1939, 1999: A föld és az állam. In: Csizmadia S.-Molnár G.-PATAKi G. Zs. (szerk.): Geopolitikai szöveggyűjtemény. Stratégiai és Védelmi Kutatóintézet, Budapest. pp. 36-48. 


\title{
DZSENTRIFIKÁCIÓ SZÖUL BELVÁROSÁBAN - CSHONGGJECSHON
}

\author{
KOUDELA PÁL \\ GENTRIFICATION IN SEOUL'S DOWNTOWN - CHEONGGYECHEON
}

\begin{abstract}
Until the mid-20th century, the historic center of Seoul was divided by a stream in a west-east direction. By the 1950s, the water of the stream had become so polluted that only the full coverage of it could solve the resulting problems. An elevated highway was built in its place. At the turn of the millennium, as part of the rehabilitation of the district, the former creek was excavated, the road demolished and an artificial natural environment created. Although the reconstruction was intended to strengthen the historic character of the city center, the artificial watercourse and the emphasized role of tourism discredited the project to socially-minded critics. In this study, we present all of this, but go one step further and interpret the socio-economic damage resulting from the disintegration of local communities in the working-class neighborhood that has developed over the decades as the cost of renewal.
\end{abstract}

Keywords: gentrification, Seoul, urban planning, urban reconstruction

\section{Bevezetés}

Nagyvárosok belső területei gyakran válnak túlzsúfolttá, a belső területek népességének ciklikus növekedése (HALL, P. 1971; VAN DEN BERG, L. et al. 1987) közlekedési, környezeti és társadalmi problémákat hoz létre. Ez történt Szöulban is, ahogy az 1960-as éveket követő szokatlanul gyors iparosítás és urbanizáció a nyugati nagyvárosi tapasztalatokhoz képest is kiemelkedően magas népsűrűséget és a zsúfoltsággal járó problémákat hozott magával. Cshonggjecshon környéke Szöul történelmi belvárosában azonban már a háborút megelőzően, a japán megszállás időszakában is zsúfolt volt (1.ábra). Az évszázadok alatt kialakított csatornahálózat következtében a valaha ott húzódó patak természetes vízutánpótlása megszűnt, vize szennyezett lett. Az ebből fakadó környezeti-egészségi problémák megoldására csak annak befedésével tudott válaszolni az 1950-es évek városvezetése.

Tanulmányunkban arra keressük a választ, hogy az ezredfordulótól egyre nagyobb teret kapó neoliberális városvezetés szempontjai - vagyis a turisztikai célú revitalizációs fejlesztési megoldások és a város fenntarthatósága, valamint a társadalmi-gazdasági szempontok - milyen új konfliktusokat teremtettek a terület felújítása kapcsán. Célunk, hogy a revitalizáció közvetlen ökológiai és gazdasági előnyei mellett a közvetett hatásokat és a politikai kontextus szerepét is megvizsgáljuk az elemzés során, amelyek a teljes átalakítási folyamat mérlegét és a regionális sajátosságokat is más megvilágításba helyezik.

Ma már a legtöbb nagyvárosi revitalizációs projektet erős társadalomkritika követi; erre is igyekszünk kitekintést adni az elemzés során. Ez a társadalomkritikai megközelítés egészen a 60-as évekig nyúlik vissza, gyökereit elsősorban az amerikai nagyvárosok belvárosi területeinek felújítását kísérő társadalmi mozgalmak és szociológiai elemzések között kereshetjük, talán a legfontosabb két kutató, akiket érdemes kiemelni JACOBS, J. (1961) és GANs, H. (1962). Ám ez a szemlélet a hosszú múlt ellenére napjainkban sokszor elsikkad, még a legszigorúbb vizsgálatok során is. A Szöul belvárosában létrehozott zöldutat számos kritika érte a szakma, a média, a közvélemény és a politikai szereplők részéről egyaránt. 


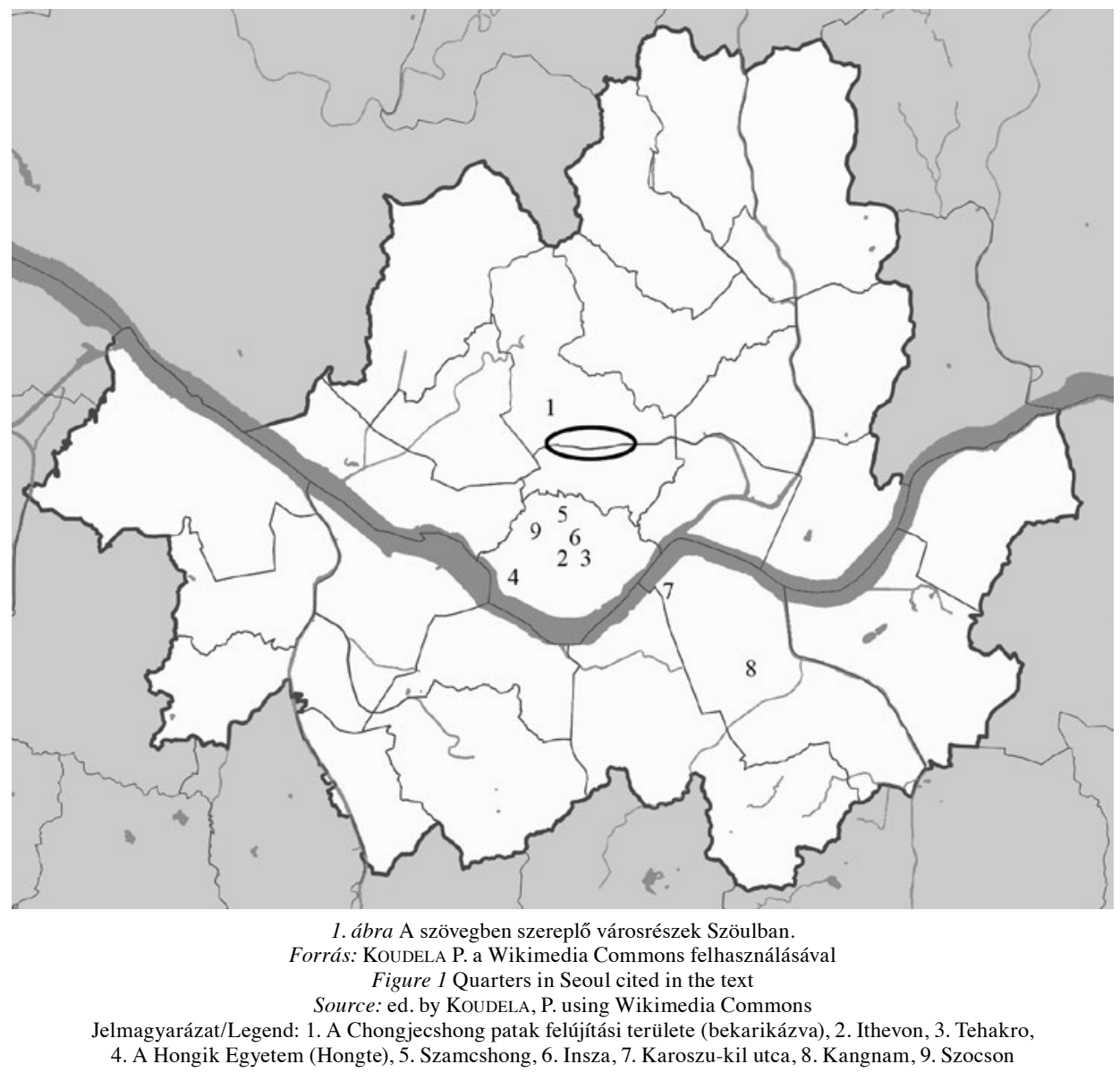

Köztük számos eltérő szempont jelent meg, hiányolható azonban a felújításnak a patak közvetlen környezetében évtizedeken át létező vállalkozói kapcsolat hálózatára gyakorolt hatásának a kimutatása. A revitalizáció során hangot kaptak a beruházók, a városvezetés és politikai riválisai, a város egészének közvéleménye és az általuk képviselt kritikai szempontok (környezeti károk, aránytalan költségek, történeti hitelesség hiánya), valamint készültek környezeti hatástanulmányok is. Ezek közül azonban a szociológiai szempont hiányzott vagy elsikkadt, sôt, társadalmi szempontból lényegében minden oldalról pozitív megítélést kapott a projekt. Jelen tanulmány a korábbi kutatásokhoz képest nagyobb súlyt helyez a területen élő vagy múködő, alacsony státuszú, zömében kiskereskedőből és kisiparosokból álló társadalmi csoportra gyakorolt hatásra.

A koreai főváros belvárosában az ezredfordulón zajló revitalizációhoz kapcsolódóan több kérdés merült fel. Így pl. hogy a projekthez kapcsolódó hatásvizsgálatok minden részletre kiterjedtek-e, beleértve a társadalmi tényezóket, és hogy a kalkulált költségek a felújítás során közvetlenül érintett területekre gyakorolt gazdasági hatáson túl figyelembe vették-e a város egészére, illetve az érintett területtel gazdasági-társadalmi kapcsolatban álló szomszédos területekre gyakorolt hatást. Ide sorolhatjuk a terület turisztikai szerepének várható megnövekedését, a lokális munkaerőpiacot, a helyi szolgáltatásokat 
és a szomszédos területekkel való funkcionális átfedést. Ugyancsak fontos kérdés, hogy a hazai és nemzetközi téren is nagy médiavisszhangot kapó projekt politikai szerepe menynyire fedte el az összetett társadalmi-gazdasági problémákat, vagy azok egy részét, illetve mekkora a szerepe a regionális elhelyezkedésnek és az ország sajátos városszerkezetének.

A kelet-ázsiai országok kapcsán JoHnson, C. (1982) könyve óta a területi átalakításokat a városrehabilitációt is fejlesztő állam kontextusában értelmezik (SAGER, T. 2011; LEE, Y-S.-Shin, H. R. 2012; Shin, H. B.-Kim, S-H. 2015; PARK, J. 2019; Khan, S. et al. 2019). Különösen fontos ez a szempont Szöul esetében, mert noha más nagyvárosok vezetése is fontos politikai szerepet tölt be egy adott ország életében, Koreában Szöul polgármestere a második legfontosabb politikai pozíciónak számít. A 2002-es polgármester-választás során fontos szerepet kapott a Cshonggjecshon patak és környéke helyreállítása. A választás ugyanakkor politikai fordulatot hozott, a korábbi konzervatív városvezetés helyére lépó új neoliberális irányítás az állam (valamint a városvezetés) gazdasági szerepét is átalakította, és a gazdasági növekedés helyett a város lakóinak jólétére helyezte a súlyt. Mindezen körülmények ugyancsak újszerú megvilágításba helyezik a rehabilitációs projektet és annak társadalmi-gazdasági következményeit. Vizsgálatunk elsősorban a már lefolytatott kutatások és a polgármester-választás miatt különösen nagy sajtónyilvánosság eredményeit hasznosítja. Célunk az ismert tények újrarendezése és olyan szempontok érvényesítése, amelyek a korábbi kutatásokban nem szerepeltek. Ugyancsak célunk annak megvizsgálása, hogy a sajátos kelet-ázsiai gazdaságpolitikai környezet vajon másképpen hat-e a dzsentrifikációra Szöulban, mint a nyugati nagyvárosokban.

\section{A dzsentrifikáció}

A dzsentrifikáció egy adott városi - általában belvárosi - terület lakosságának kicserélődését jelenti, amit egyfelől a területen alkalmazott városfejlesztési stratégia, másfelől spontán migrációs folyamat is kiválthat. A dzsentrifikáció modellezésére számos elmélet született, hátterében azonban általában hasonló jelenségek állnak. A nagyvárosok túlzsúfoltságával, a foglalkoztatási szerkezet és a szektorok átalakulásával a város belső területein élő középosztályi rétegek, majd az 50-es, 60-as évektől a felemelkedő munkásosztályi rétegek is egyre gyakrabban változtattak lakóhelyükön, s költöztek a nagyvárosok körül húzódó kertvárosokba. Ezt a folyamatot szuburbanizáció vagy whiteflight néven foglalja össze a szaktudomány (KIM, J.-KIL, H. K. 2019). Egészében meglehetősen heterogén jelenségről van szó, ezt és a vele foglalkozó kutatásokat, valamint azok kaotikus voltát érzék-

letesen mutatja be BERÉNYI B. E. (2016) összefoglaló munkája. A tömeges kiköltözések következtében a nagyvárosok belső területein a társadalmi összetétel homogenizálódott és egészében véve leromlott. Különösen a csökkenő fizetőképes kereslet és az etnikai szigetek kialakulása következtében ehhez társult még fizikai romlás is, ami a városkép egészére is negatívan hatott. A dzsentrifikáció elméletének részletes bemutatása nem célunk, erről számtalan könyv és folyóiratok tematikus számai szóltak ez elmúlt években (pl. LEES, L. 2000, 2012; Atkinson, R. 2003; Smith, D. P.-Butler, T. 2007; Shaw, K. 2008; Lees, L. et al. 2010; RÉPAT, P. et al. 2010; DouCET, B. 2014; részletesebben 1. in BERÉNYi B. E. 2016). Fontos azonban megjegyezni, hogy a dzsentrifikáció nem csak nagyvárosokra jellemző folyamat, amint azt hazai példákon is tapasztalhatjuk. (NAGY E.-IzsÁK É. 2017).

A dzsentrifikációt egyfelől a városvezetés által kezdeményezett revitalizáció - amit sokszor meg is különböztetnek a dzsentrifikáció szűkebb jelentésétől (PAMUK, A. 2005) -, másfelől a megürült helyekre középosztályi csoportoknak a belváros közelsége miatti beáramlása váltja ki (LEES, L. et al. 2010). Az 1990-es évektől a világ minden táján általános 
gyakorlattá vált a belső területek revitalizációja a városi önkormányzatok és a magántőke együttmúködésében (SMITH, N. 2002), ami Szöulban is konfliktusokat szült (LEE, S. Y. 2018; SHin, H. R. 2009). A dzsentrifikáció elősegítésére kormányzati szinten adókedvezmények és más lakáspolitikai ösztönzők is alkalmasak (MELE, C. 2000), sőt kizárólag a magántőke is kelthet spontán reurbanizációs folyamatot. Hazánkban hasonló jelenséggel már a rendszerváltozás előtt is találkozhattunk, majd az 1990-es években Budapest számos kerületében zajlott le rehabilitáció, amelynek társadalmi hatását egészében EGEDY T. (2007), konkrét példaként pedig Erzsébetváros nagyszabású építkezéseinek vonatkozásában CSANÁDi G. et al. (2006) elemezte. Általánosságban elmondható, hogy a dzsentrifikáció során az épület- és lakásállomány megváltozása következtében nemcsak azok piaci értéke, hanem stílusa is megváltozik, így a lakosságcsere nem egyszerűsíthetô le a jövedelmi csoportok szintjére; az ilyen területi-társadalmi folyamat etnikai csoportok vagy eltérő miliők - általában a belváros és a peremterületek, illetve kertvárosok - közötti területi cserét is jelent (Hedin, K. et al. 2012; RandolPh, B.-Tice, A. 2014; CoOKe, T.-Denton, C. 2015; Harrison, S.-JaCoBS, A. 2016; KaVAnaGH, L. et al. 2016).

Aligha szükséges bemutatnunk, hogy a dzsentrifikáció mint társadalmi folyamat és a város fizikai megújítását célzó rehabilitáció között mi a különbség, sem azt, hogy a kettő között milyen összefüggések találhatók. Noha minden egyes város és minden eset eltér egymástól, az általánosabb összefüggések - a felújítás piaci hatása, az ingatlanárak növekedésének társadalmi hatása stb. - nemzetközi és hazai példák kapcsán is jól ismertek. A dzsentrifikáció egyúttal a hagyományos kapcsolati hálók felbomlását idézi elő és a társadalmi tőke komoly veszteségét eredményezi (HENIG, J. 1984; Bond, L. 1991; Perez, G. 2004). A lakosság fokozatos cseréje a területen múködő vállalkozásokat is érinti: a korábbi keresletet kielégítő profillal rendelkező boltok, szolgáltatások lassan elvesztik fogyasztóikat, így például egyre kevesebb kocsmára és hentesüzletre lesz szükség, a helyükre pedig jógastúdiók és elegáns bisztrók költöznek. Ezzel az ott foglalkoztatott, általában helyi lakosok a megélhetésüket is elvesztik, így kénytelenek munkájukat másik városrészben folytatni (SHAW, K. 2005; WyLY, E. K.-HAMMEL, D. J. 2005). Mindez szükségszerűen feszültségeket is szül a régi és új lakosok között (ZuKIN, S. 1987). Sok esetben a beköltözők első hulláma éppen a hely olcsósága és a városközponthoz való közelsége miatt költözik oda, gyakran fiatal múvészek közül kerülnek ki a beköltözők, akik számára a városrészt elhelyezkedése és ,ppatinája” teszi vonzóvá. Ez egyúttal sajátos atmoszférát hoz létre, ami önmagában is felértékeli a területet, így mire az orvosok, ügyvédek és üzletemberek is megérkeznek, az ingatlanárak már olyan magasba szöknek, hogy a múvészek nagy része kénytelen továbbköltözni (CLAY, P. 1979; KERSTEIN, R. 1990).

Ez történt Szöul Hongte nevű kerületében is, ami leginkább nyüzsgő múvészeti életéről és az ún. indie zene - egy mára önállóvá vált könnyúzenei múfaj, amelynek neve az independent, azaz független szóból származik - koreai otthonaként volt ismert. A kerület kormányzati beruházások révén indult fejlődésnek 1999 és 2005 között, ám a múvészek, az ingatlantulajdonosok, valamint a terület felújításába bevont mérnökök között feszültségek alakultak ki, a tulajdonosok spekulációi a luxusmárkák üzleteinek és az elegáns kávéházaknak kedveztek, míg a zenei stúdiók és maguk a múvészek kénytelenek voltak alacsonyabb bérletű területekre - sokan közülük Ithevonba - költözni (CHO, M-H. 2010). Ugyanakkor pl. a Castro negyedet az ott élő közösségek érdekérvényesítése és intézményei meg tudták védeni (CASTELLS, M. 1983). Az ezredfordulóra a termelésalapú gazdaságot posztindusztriális, tudás- és szolgáltatásalapú gazdasággal helyettesítő neoliberális gazdasági fejlődés, valamint a hozzá kapcsolódó várospolitika következtében (HILL, R. C.-KIM, J. W. 2000) az ázsiai országokra is jellemző lett ez a fajta területi homogenizáció. Ennek a folyamatnak a városi területek átalakulásában is meghatározó szerepe van. 
ZuKIN, S. már a kilencvenes évek elején kimutatta, hogy a „bohém” életstílust követő társadalmi csoportoknak meghatározó szerepük van a dzsentrifikációban. Ezek - az o megfogalmazásában a „kritikus infrastruktúrát” alkotó - csoportok nemcsak sajátos esztétikai szemléletükkel, hanem fogyasztói szokásaikkal is befolyással vannak a dzsentrifikáció folyamatára. A tömegfogyasztás korában az általuk megteremtett miliő egyfajta viszonyítási pontot jelent mások számára, vonzóvá teszi az általuk ,átformált” területet a középosztály szélesebb tömegei számára. New York és Los Angeles példáján egyértelmúen bebizonyosodott, hogy a múvészet - különösen a galériák és kiállítások - jelenléte a nagyváros globális versenyhelyzetét is növeli (ZUKIN, S. 1991, 1995). A múvészek és más kreatív csoportok jelenlétére alapozott városok közötti verseny gyakorlati megvalósításához a legismertebb - és legvitatottabb - elméleti modellt FLORIDA, R. (2002) hozta létre. A kreatív gazdaság szerepéről Magyarországon KovÁcs Z. et al. (2011) elemzésében olvashatunk részletesebben.

FLORIDA természetesen élt a lehetőséggel, hogy eme felfedezését „megossza” az arra igényt tartó nagyvárosok irányításával, ez utóbbiak pedig remekül használják azt ma is a gazdaság élénkítéséhez és a versenyképesség növeléséhez. Mindez azonban tudatos stratégiákat hoz létre, ami végső soron a nagyvárosok belvárosi területeinek felértékelését és dzsentrifikációját eredményezi (LeY, D. 2003; PECK, J. 2005). Egyúttal tökéletesen kifejezi a folyamat összetettségét: a dzsentrifikáció akár demográfiai folyamatként, akár a revitalizáció következményeként való egyszerú és egydimenziós leírása mindenképpen leegyszerűsítő lenne, hiszen így mint összetevők kimaradnának a közpolitikai, történeti vagy társadalmi mozgalmak és a kulturális, illetve az életstílushoz kötődő hatások.

\section{A dzsentrifikáció háttere Dél-Koreában}

Dél-Koreában egészen látványos mértéket ölt a dzsentrifikáció. A gazdaság élénkítése, a nemzetközi verseny elkötelezetté tette a mindenkori kormányokat, így a szokásos tíz-húsz éves rehabilitációs folyamat hamar öt évre, mára pedig két évre rövidült (KwON, Y. et al. 2017), s olyan nagymértékben zajlik, hogy a városok átalakulásának egyik legfontosabb tényezőjeként tarthatjuk számon. Néhány példa a teljesség igénye nélkül:

- Tehakro Szöul színházi és diáknegyede; utcai zenészek és fiatalok kávézói színesítik, múvészek múhelyei tarkítják ezt a városrészt, amelynek két évtizedig tartott az átalakulása.

- A fentebb említett Hongte városrész a Hongik Egyetem környéke Szöul belvárosának nyugati felében; az indie zene és városi múvészet színtere.

- Szamcshong dombos kerülete; hagyományos koreai épületei, múvészeti galériái, boltjai és éttermei mellett számos külföldi konzulátusnak is helyet biztosít.

- Insza városrész; teázók és galériák színtere, korábban a legnagyobb antikvitás- és múkincspiacnak adott otthont.

- Kangnam, a fákkal szegélyezett Karoszu-kil utca; drága butikok, éttermek és kávézók környéke.

- Szocson, Szöul belsô területe északi részének egyik legrégibb negyede; a szépirodalom egyik központja, tele történelmi emlékekkel, Szedzsong király szülőhelye, a samanizmus kedvelt helyszíne.

A dzsentrifikáció során átalakult városokban, városrészekben találunk történelmi rekonstrukciót, reurbanizációs-múvészi, üzleti és yuppie negyedet is. Létrejöttükben helyenként a kormány vagy a városvezetés, máskor a befektetôk vagy a piac játssza a fő 
szerepet, és míg pl. Tehakrónak két évtizedig tartott az átalakulása, addig Szocsonban már csak két évbe telt, mire mai, divatos jellegét elnyerte a 2010-es években.

A legfontosabb különbség, amit HiLl, R.C.-KIM, J. W. (2000) hangsúlyoz, hogy a nyugati országokkal szemben Korea (akárcsak Japán) nem piacorientált és bürokratikus, legalábbis nem a hagyományos weberi értelemben. Ehelyett sokkal inkább államközpontúak és bürokráciájuk politikai jellegú. Erre a kelet-ázsiai megkésett iparosodás körülményei közt sajátosan alakult állami szerepkörre alkotta meg JoHNSON, C. (1982) a fejlesztő állam koncepcióját, ami nem feltétlenül a neoliberális, a globalizáció kihívásaival szembeforduló szerepkört jelentette, csupán a nyugati országoktól lemaradt gazdaságok felzárkózásának sajátos, gyors, és a helyi történeti hagyományokba és értékrendszerbe illeszkedő megoldását vezette be. Ideológiai okokat firtatni félrevezetô lehet olyan esetekben, amikor pragmatikus gazdasági célok voltak meghatározók.

1995-től az állami hatalom helyi szintre történő átruházásával párhuzamosan a helyi önkormányzatok fejlesztő szerepe egyre inkább szembetűnővé vált. A fejlesztés érdekében decentralizált hatalom szerepe egyaránt megmutatkozik a várostervezésben és abban, ahogy a helyi önkormányzatok és megválasztott vezetőik részt vesznek a hatalmas léptékű piacorientált városfejlesztési versenyben, beleértve a lakhatási és kulturális fejlesztéseket, a belvárosok megújítását, vagy akár a városi természeti környezet helyreállítását. Mindezek a városi tér újraértékelésére irányulnak. A városi versenyképesség fokozásának érdekében a városfejlesztési projekteket úgy tervezték, hogy a várost tegyék az állam által jóváhagyott piaci növekedés új motorjává, és az meghatározó mértékben bérleti rendszer formájában múködjön. Noha mindezeknek nyilvános konzultációkon és értékelésen alapuló tárgyalási folyamatokon kell keresztül esniük, ezeket nyilvánvalóan a helyi növekedésben érdekelt koalíció irányítja, amely az állam és a piac társult, a civil társadalommal szembeni érdekeit tükrözi.

A 2011-es választás után a nemrég elhunyt PAK VONSZUN polgármester nevével fémjelzett progresszív önkormányzati vezetés ezzel szemben egy emberközpontú várospolitikát valósított meg. A megaprojektekről a civil szervezetekre, a városi térről a város népességére, míg a bürokratikus kormányzásról a demokrácia szélesítésére helyeződött a súly. 47 új polgári bizottság jött létre, amelyek mindegyike városi rendeleten alapult. A bizottságok különböző megbízásokat kaptak a polgármester kampánytámogatási projektjei kapcsán - ilyenek voltak az „Eggyel kevesebb atomerómúvet”, vagy a szociális gazdaság és a részvételen alapuló költségvetés végrehajtására irányuló terv kidolgozása -, és felhatalmazást kaptak arra is, hogy a polgárokat bevonják a várostervezésbe, így a paszszív részvétel helyett a társadalmi innováció kezdeményezőivé válnak, kifejtve a városhoz való jogukat (CHO, M-R. 2018). A választást követően kezdetben még csak az ingyenes iskolai étkeztetésről folyó vita a jóléttel kapcsolatos általános közéleti konfliktussá nőtte ki magát a politikai erők között. A konkrét vita lényege az volt, hogy míg a konzervatív ún. neo-developmentalista - az IMF és a Világbank által fémjelzett szabadpiaci gazdaságpolitikával szemben álló, a nemzeti kapitalista fejlődés útján a teljes foglalkoztatás elérésére törekvő - párt válogató támogatási rendszert szeretett volna bevezetni, vagyis csak a szegény gyerekek részesültek volna ingyenes étkezésben, addig a progresszív ellenzéki erôk univerzális támogatást javasoltak, hogy a szegény gyerekeket ne stigmatizálja a csak nekik járó ingyen ebéd, amit csak ők kapnának a menzán. Ezt a konzervatívok populista politikának tartották, ami ráadásul az önkormányzatoknak túlzott anyagi terhet jelentene.

A politikai szemléletváltás a nagy visszhangot kapó projektek kapcsán fellángoló vitákban is testet öltött. Cshonggjecshon nemrégiben lezajlott revitalizációja is új értelmezést és megítélést nyert. PAK a megaberuházásoktól elvont pénzből a jóléti rendszereket fejlesztette: a költségvetésben 30\%-ra nőtt a jóléti kiadások aránya. Egyebek közt fejlesztette az 
egészségügyi ellátást, 80 000-rel növelte az állami bérlakások számát, kiterjesztette a pénzbeli támogatások körét, bővítette az állami óvodai ellátást és a mozgáskorlátozottak közlekedését speciális taxiszolgáltatással segítette. A jólét nem jótékonyság, hanem a polgárok alapvető joga - fogalmazta meg a polgármester alapeszméjét a polgárok jogáról a befogadó élethez a közösségekben és a városban.

Százával nyíltak a helyi könyvtárak, múzeumok, workshopok, kiállítótermek és egyéb közösségi kulturális létesítmények Szöul-szerte. PAK polgármester elképzelése egy boldog város volt, amelynek gazdasági, jóléti és kulturális összetevői mellett a szuverenitás és a fenntarthatóság is fontos alkotóelemei. Az ő eszmei hátterét nem FLORIDA, R. (2002) kreatív osztálya, hanem egy ahhoz hasonló másik koncepció, a dán JENSEN, R. (1999) „álom társadalma” adja: a The Copenhagen Institute for Future Studies korábbi igazgatója, a Dream Company alapítója, több mint száz nagy nemzetközi vállalat és kormányzat tanácsadója modelljét az információs társadalmat követő szakaszról fogalmazta meg.

\section{A történelem és természet újjáélesztése - Cshonggjecshon}

A szöuli városfejlesztés hosszú évtizedeken át elsősorban a gazdasági növekedést, illetve a várost körülölelő zöldövezet esetében a nemzetbiztonsági szempontot tartotta szem előtt. A háború utáni években megindult tömeges bevándorlás azonban nem csak új általános várostervezési és -irányítási elveket kényszerített ki, hanem egyes területek esetében közvetlen beavatkozást is igényelt. Ezek közül talán a legismertebb a város középpontjában található Cshonggjecshon patak befedése volt.

A várost kettészelő nyugat-keleti főút a patak mentén futott, míg a mellékutak annak mellékágai mentén épültek ki. A vízgyújtőrendszert a városfal és a domborzat zárta körbe. Az évszázadokig meghatározó szerepú folyó medrét idővel mesterségesen kiszélesítették és rakpartját kőből építették ki - erre utalt eredeti neve: Kecshon, azaz 'kiásott'-, majd évszázadokon keresztül csatornaként használták a város szennyvizének elvezetésére. Új 'tiszta vizú patak' jelentésű nevét a japán megszállás alatt kapta, noha ebben az időszakban már igen szennyezett volt. A húszas években a mellékágak egy részét befedték és csatornává alakították, megteremtve Szöul csatornarendszerének alapjait, s számtalan terv született az egész patak befedésére is, ami anyagi fedezet hiányában csupán egy kisebb részén valósult meg. A koreai háború alatt menekültek nyomortelepei épültek a part mentén, és Cshonggjecshon a megszállás mementójává, a szegénység és a nyomor szimbólumává vált (1. kép). A végletesen szennyezett patakot végül az adott korszakban bevett és elfogadott városépítési megoldásoknak megfelelően a jelentős gazdasági nehézségek ellenére be kellett fedni (JEON, C.-KANG, K. 2019) (2. kép).

A patak befedése 1958-ban kezdődött, betonburkolatára út került, partjain a korábbi nyomornegyedeket üzemek és piacok kezdték felváltani. 1977-re a városközpont ütőereként egy emelt szintű autópályát is építettek fölé. Az út forgalma évről évre nőtt, 2002-ben már napi 170000 jármú haladt át rajta (KURNIAWAN, M. 2016). A gyorsan fejlődő terület hamar az ipar és kereskedelem központjává, ezzel együtt pedig a fejlődés és modernizáció jelképévé vált. A patak, illetve immár sztráda mentén új iparágak központi épületei emelkedtek: a gép-, az elektronikai, a textil-és a ruhaipar kezdte uralni a környéket. A hetvenes évektől a legmeghatározóbb elem a kisgépek és eszközök gyártása és javítása lett. A mellékutcák kopott épületeiben bármilyen alkatrészt vagy gépet megvásárolhatott a járókelő a kis boltokban. A nyomornegyedeket egyfajta hektikus iparosodás és szervezetlen fejlődés képe váltotta fel. A jármúvektől, hordároktól, dobozoktól és járókelőktől zsúfolt utak látképét számtalan olcsó étterem és kávéház egészítette ki. 


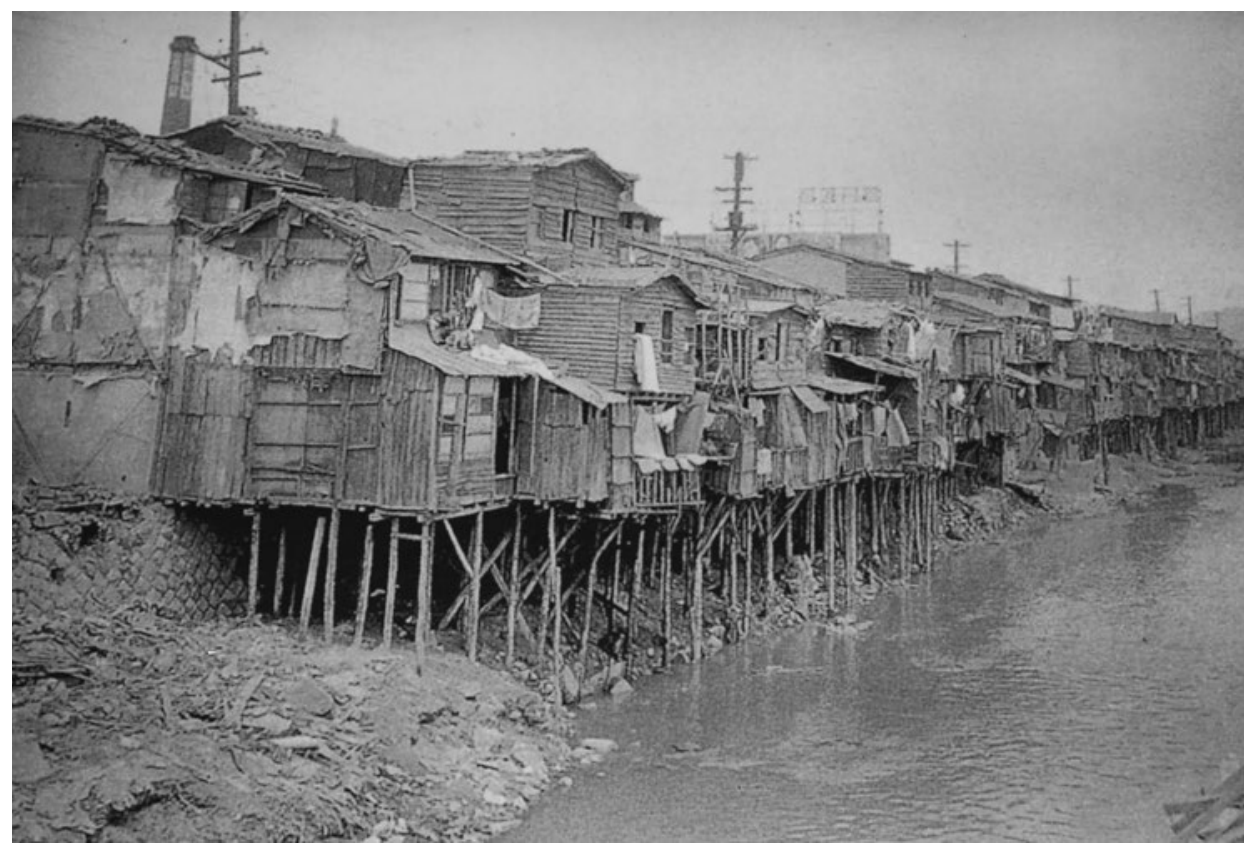

1. kép A háború után, az észak-koreai menekültek által épített viskók a Cshonggjecshon patak mentén Photo 1 Shantytowns built by North Korean refugees after the war, along with the Cheonggyecheon Stream Forrás/Source: Mary and Doug Malo

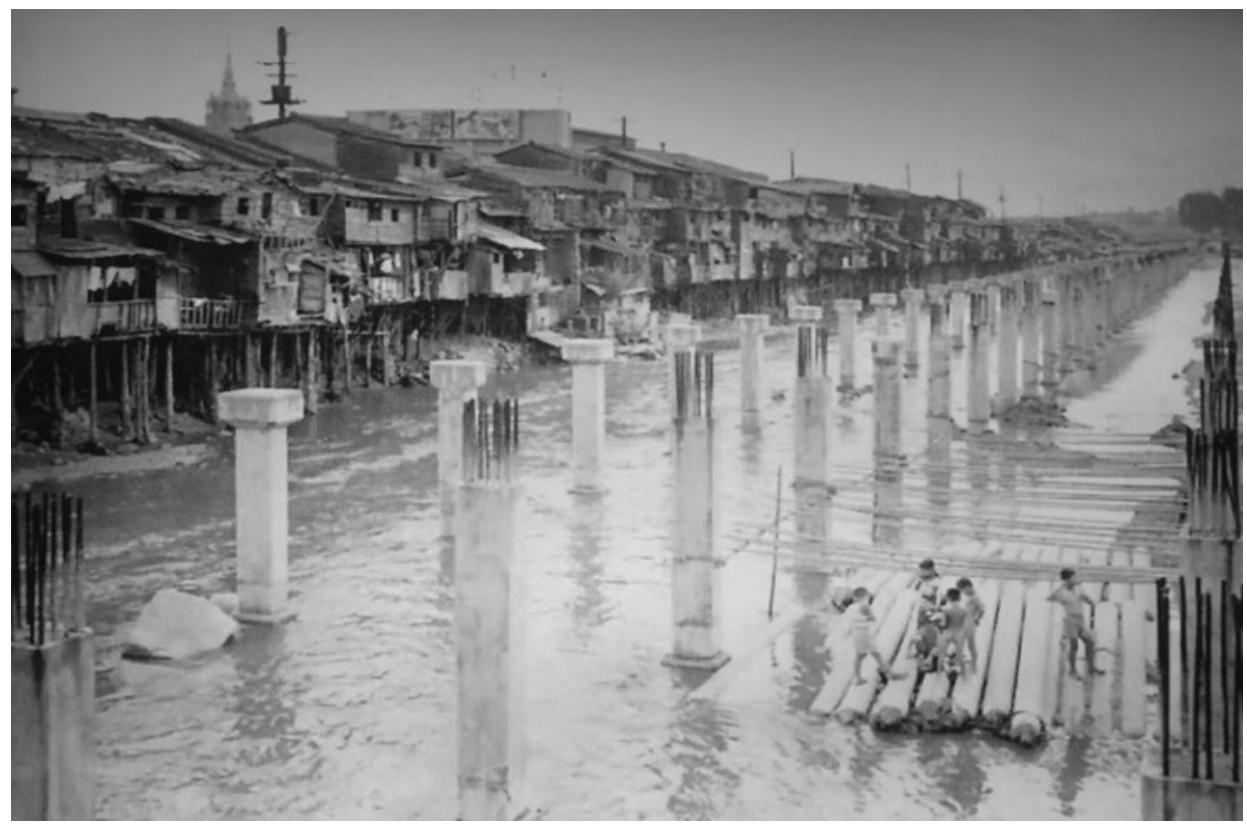

2. kép A Cshonggjecshon patak befedési munkálatai 1958-ban

Photo 2 Covering the Cheonggyecheon Stream in 1958

Forrás/Source: Mary and Doug Malo 
A hetvenes évektől ezt a környéket a zsúfolt kisüzemek és a munkaerő kizsákmányolása tette hírhedté. Az 1997-es gazdasági válságot követô években a sztráda árnyékában meghúzódó piszkos utcák mindenkinek a gazdasági fejlődés negatív irányát juttatták eszébe, nem csoda, hogy éppen ekkor merült fel a gondolat a patak újbóli feltárására és az egész terület rekonstrukciójára. A részletekbe menő vitát szakértők, mérnökök egy csoportja kezdte, akik első szimpóziumukat 2000 szeptemberében tartották. Az ő nyomásgyakorlásuk a 2002-es polgármester-választás jelöltjeire indította el azt a folyamatot, ami az anyagi és technikai feltételeket megteremtette a felújításhoz. A konzervatív jelölt a patak felújítását a város északi felének általános gazdasági revitalizációjához kapcsolta, ami nagymértékben hozzájárult a győzelméhez a demokrata jelölttel szemben, aki a magas költségek, valamint a fokozódó közlekedési gondokkal kapcsolatos félelmei miatt mindvégig bizonytalan maradt a rekonstrukciót illetően. I MJONGBAK, a konzervatív jelölt hírnevét az 1968-1970 között épült Szöul-Puszan autópálya építése során szerezte, mint a sztrádát kivitelező Hyundai munkatársa (3. kép). I hamar legendássá vált, különösen amikor 1977-ben, mindössze 35 évesen beválasztották a Hyundai vezetőségébe. A politikai életbe 1992-ben lépett be, majd 1995-ben javaslatot tett a Szöul és Puszan közt kiépítendő csatornára. A terv a két nagyvárost átszelő folyók összekötésére irányult, és bejelentését követően hatalmas nemzetközi vitát generált (CYRANOSKI, D. 2008), de végül 2007-ben sikerült elfogadtatni (PAK, Sz-H. 2008). A később elnök ké is megválasztott I üzleti karrierje - ami sokszor hivatkozott forrássá vált, amikor Szöul posztmodern, környezetbarát ipari átalakulásáról volt szó végül sajnálatos módon 2018-ban csúfos véget ért, ugyanis sikkasztás vádjával a bíróság tizenöt év börtönbüntetésre és hatalmas kártérítésre ítélte (AP).

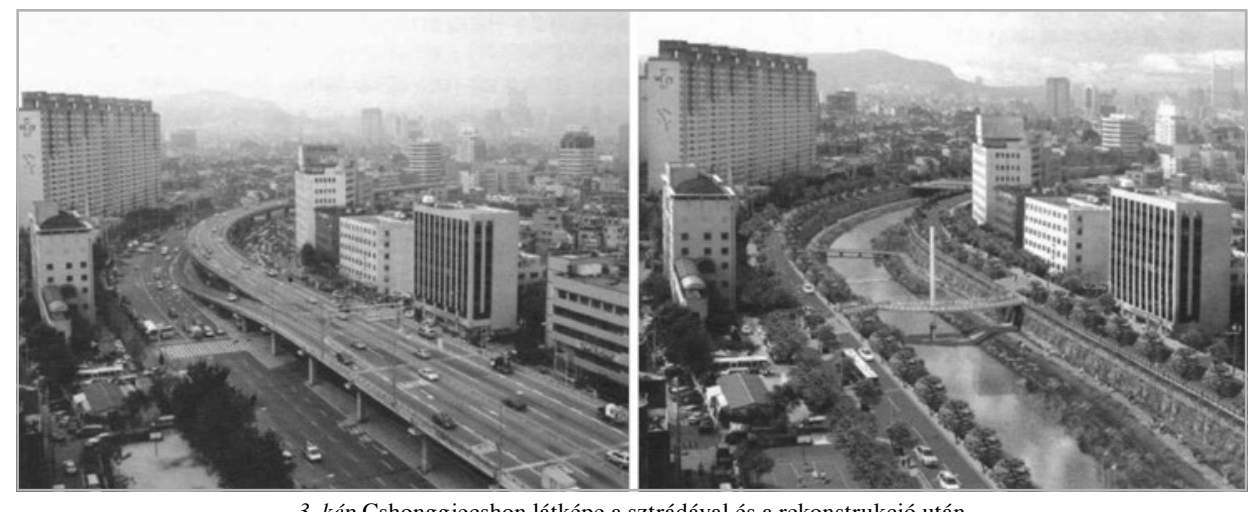

3. kép Cshonggjecshon látképe a sztrádával és a rekonstrukció után Forrás: ReIs, L.-DA SiLva, R. (2016) nyomán

Photo 3 Aerial view of Cheonggyecheon with the elevated highway and after the reconstruction Source: after REIS, L.-DA SILVA, R. (2016)

Cshonggjecshon felújítása illeszkedett a 2000-es évek várostervezési szemléletébe. Ekkor vált uralkodóvá az ökológiai és történelmi szempont, a parkok már nem csak rekreációs szerepet töltöttek be, hanem a város természetes környezetét bővítették, javították, a történelmi emlékek kiemelt jelentőséget kezdtek kapni. A várostervezők igyekezték a főváros hatszáz éves történelmét a város mindennapjaiban, az utcákon is tetten érhető identitássá változtatni. A Kvakhvamun-kapu felújítása 2006 és 2009 között, valamint az azonos nevú park felépítése hasonlóképp jól példázza a városrehabilitáció 21 . század eleji trendjét, de említhetnénk a kétezres évek elején az erdőlétesítési tervet is, ami nem hagyományos parkokat, hanem természetes erdők telepítését tűzte ki célul (CsoNG, Sz-J. 2014). 


\section{A belváros revitalizációja}

\section{A zöldút kialakítása}

A 2003-2004-ben zajló felújítás - bár sok romantikus elképzelés is kapcsolódott hozzánem volt olyan egyszerű. Indokai a romló állapotú sztráda és környezete, annak fizikai veszélyei, a környék gazdasági revitalizációja és a környezetszennyezés megszüntetése voltak. Ugyanakkor a patak vízhozamát eredetileg biztosító mellékágak idővel mind be lettek csatornázva, így lényegében ma is a Han folyóból kell napi 98000 tonna vizet átszivattyúzni a patakba, amelyből az visszafolyik a Han folyóba. Mindezt a közeli metróállomáson összegyúlő vízzel egészítik ki. Ekkora mennyiségű vizet felszivattyúzni minden nap természetesen hatalmas energiafelhasználást, következésképpen környezeti terhelést jelent, ami ellentmond az egész terv ökológiai céljának (CHO, M-R. 2010). A fentiek fényében a patak inkább az infrastruktúra-fejlesztés technológiai eredménye, mintsem a természeti környezet visszaállítása lett; más szavakkal sokkal inkább múvi vízfolyás, mintsem patak (RIEH, S-Y.-ChANG, J. 2018).

Noha a közéleti szakemberek általános véleménye negatív volt, a város lakóinak körében igen népszerű lett a fejlesztés. Mindjárt az első években havi 6,62 millió látogatót vonzott, s a város saját felmérése szerint a lakók 98\%-a elégedett volt a felújítással (Cso, M-R. 2005). Gross, M. (2002, 2003, 2005) az ökológiai helyreállítást egyfajta „társadalmi kísérletnek" nevezi: a társadalom és a természet kapcsolatának. Mindez azonban attól függ, hogyan értelmezik az emberek a természetet, és hogyan használják fel a természet értékeit és elemeit a meglévő kulturális kontextusban és intézményekben. Az ilyen kísérletek egyúttal a természeti értékek és embercsoportok közötti dinamikát is közvetítik. Az ökológusok, akik a természet objektív értékeit veszik alapul, az adott környezeti komplexumot lehetőség szerint az eredeti állapotába állítják vissza, céljuk az emberi élet rendjét a természethez igazítani. Másrészt azok a környezetvédők, akik a természetre mint eszközre tekintenek, magát a helyreállítást is a természetes folyamatnak tekintik, amivel az emberi élet kényelmesebbé tételét segítik. Az egyik a restauráció tárgyáról és valóságáról, a másik a restauráció módszereirôl és eljárásairól szól.

Valójában tehát két ellentétes szemlélet ütközött egymással: míg a környezetvédelem oldalán állók ökológiai szempontokból indultak ki, addig a város vezetése a várostervezés felől közelítette meg a helyreállítást. Az előbbi az „ökológiai kulturizmust” használja a városi életminőség javítására a folyók ökológiájának maximalizálása révén, az utóbbi a folyók környezeti elemeit használja a város újjáélesztésének és végső soron a városfejlesztésnek a céljára. (Az ökokulturális kritikai szempont az ember és környezete, valamint a társadalmi és politikai viszonyok egyidejú vizsgálatára koncentrál, és ennek a két viszonyrendszernek az egymásra hatását is vizsgálja; IvAKHIV, A. 1997). A várostervezési szempont érvényesülésének mértékét az is mutatja, hogy a folyómeder alatt 7-15 méteres mélységben egy csatornarendszert alakítottak ki, ami a kétszáz évente előforduló árvizek elvezetésére szolgál. Ilyen mértékű túlbiztosítás egyértelműen az infrastrukturális szempont dominanciáját jelzi (Cso, M-R. 2005). Persze a mesterséges tereprendezés elemei (vízesések, szökőkutak, lépcsők, falfestmények, világítóberendezések, gyalogospályák stb.) mind illeszkednek a kényelmi felhasználást szem előtt tartó tervezési célokba.

A felújítás célja természetesen nem állt meg a természeti-történeti rekonstrukciónál, az egész belvárosi környezet megújulását szándékozott előmozdítani, s a város déli, az ezredfordulóra messze fejlettebb városrészeihez (pl. Kangnam) történő felzárkózást is igyekezett elősegíteni. Maga a zöldút, amit a patak mentén létrehoztak, természetesen önálló turiszti- 
kai és környezeti értékű fejlesztés volt. Napi hatvanezer látogatójával és rengeteg rendezvényével gazdaságilag mindenképpen kifizetődő lett. Valójában éppen a tágabb gazdasági fejlesztés volt az igazi indok; Cshonggjecshon esete meglehetôsen tipikus felújítási projekt volt, amit más nagyvárosokban is megélhettek a városlakók.

\section{Cshonggjecshon felújitásának kritikai értelmezése}

A Cshonggjecshon felújítását érő kritikák szerint az ökológiai rendszer egyes elemeinek mégannyira autentikus felújítása sem válthatja ki a teljes rendszer elemei közötti szimbolikus és evolúciós interakciót. Más szavakkal mondva még akkor sem lehetne visszaállítani a környezet eredeti természeti állapotát és annak fejlődési képességét, ha magát a patakot, annak vízi élővilágát és más elemeket sikerülne helyreállítani. A teljes értékú felújítás tehát csak akkor érhető el, ha az egész környék átalakulása a környezeti komplexitás figyelembevételével zajlik, még ha ez több időbe is telik. A cél tehát nem a folyót magát újjáéleszteni, hanem a város egészét, és a folyó helyét a városon (városrészen) belül újraértelmezni. Sajnos a társadalmi párbeszéd nem zajlott le megfelelőképpen, és Cso, M-R. (2005) szerint a demokratikus folyamat sérült, ami egyben a városrész városökológiai dinamikájára is negatívan hatott, és amit a polgármester megvesztegetési botránya is gyengített. A városfejlesztés, valamint a kritikai ökológiai és kulturális szempontok csatájában a városi bürokrácia tehetetlensége ,győzött”.

A város természeti környezete mindenképpen pozitív irányba változott, a magasút lebontásával és a patak létrehozásával a levegő minősége, a napfény mennyisége és számtalan egyéb tényező ugrásszerúen javult a környéken. A drámai hatás azonban az ingatlanárak emelkedésében mutatkozott meg; ez a lakásárakban száz százalékos, míg az üzlethelységek bérleti árában harminc százalékos emelkedést jelentett a felújítás két éves periódusában. A városrész mind társadalmi összetételében, mind szolgáltatásaiban kicserélődött, a korábbi alacsony státuszú lakóépületek helyére luxuslakásokat építettek, amelyek hamar meghaladták Kangnam, Szöul legdrágább kerületének árait is. A felújítás gazdasági hatása továbbgyưrűzött és a patak 5,8 km-es szakaszán 380 milliárd von beruházást eredményezett, sôt a közvetett gazdasági hatást, beleértve a foglalkoztatást is, 60 trillió vonra becsülték, ami 2005-ös árfolyamon a 74 milliárd, illetve 11,8 trillió forintnak felel meg (Cso, M. R. 2005).

Noha a lehetőségek egyértelmú korlátokat szabtak a felújításra, a „lehetô legjobb” eredmény mégis kérdéseket vetett fel. Vajon milyen identifikációval számolhat a létesítmény: tájkép, patak, vagy patak-e egyáltalán? Ha sikerült is a természeti környezetet a lehető legjobban rekonstruálni, a környék további, a beruházás által kiváltott fejlődése mindenképpen károsan hatott arra. A legnagyobb veszteség talán mégiscsak a történelmi fejlődés lehetőségének elvesztése. Azzal, hogy egy ilyen jelentős, mégis felülről hozott döntés ilyen nagymértékben átalakította a környezetet Szöul belvárosában, az a lehetőség ment füstbe, hogy az a maga szerves, alulról építkező módján, a természetes társadalmi folyamatok révén menjen végbe.

Az igen népszerû turisztikai látványosság elvesztette identitását, történeti jelentését és az ott élő emberekkel való szerves kapcsolatát, interaktivitását, így antropológiai értelemben „nem-hellyé” (Auge, M. 1995) változott. A bírálatok a természeti és a történeti rekonstrukció hiányosságaira és alapvető elhibázottságára vonatkoztak. Hasonló problémákkal hazánkban is számtalan esetben találkozunk, érdemes összevetni Ferencváros (ToMAY K. 2006), vagy Erzsébetváros (CSANÁDI G. et al. 2008) rehabilitációjával. A projekt befejeztével nem adták át a Kvantongjo hidat a teljes forgalomnak, félve, hogy nem bírja majd a modern jármúvek terhelését, ám a kritika szerint ezzel elvesztette történeti jelentését (4. kép). A csalódott kritikusok romantikus elképzelése azonban egy olyan patakra és városra „emlékezett”, amit sosem ismertek, vagy ami sosem létezett. 1958 előtt a Cshonggjecshon 


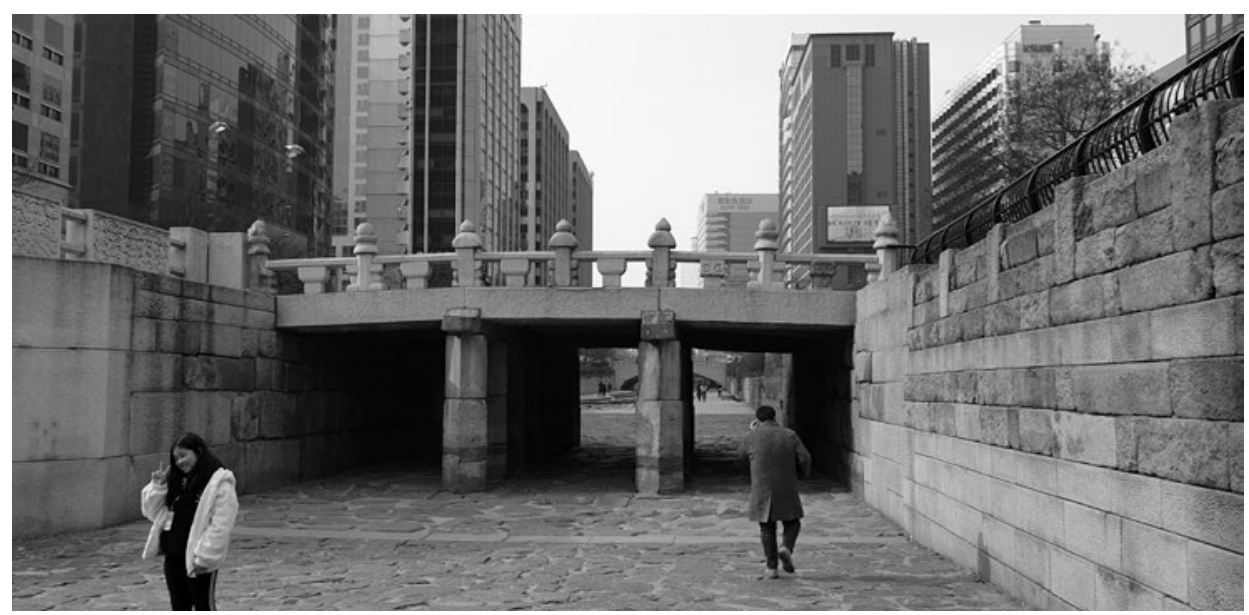

4. kép A Kvantongjo híd és környéke 2019-ben Photo 4 Around the Gwangtonggyo Bridge in 2019 Forrás/Source: KoudeLA, P.

patak, mint említettük, egy szennyvízelvezető volt, környéke pedig nyomornegyed. A befedést követő évtizedekben pedig nem volt mire emlékezni, hiszen a csatorna a föld alá került. Csatorna volt, hiszen természetes vízutánpótlását évszázadok óta elvesztette. A városépítészeti szemlélet szerint a városrész konzerválása olyan referenciára utalt, ami legfeljebb a történelemkönyvekben volt olvasható.

A 2014-ben létrejött bizottság - Cso MJONG-RE vezetésével - az újbóli rekonstrukciót szorgalmazta, de figyelmen kívül hagyta, hogy a város egy folyamatosan változó közeg. A kritikusok szerint a „tereprendezésnek” degradált városfejlesztés és rekonstrukció viszont a kerület dzsentrifikációját eredményezte (5. kép). JEON, C. - KANG, K. (2019) meg is jegyzik, hogy még a városrehabilitáció, a mesterséges tereprendezés legerősebb bírálója, a szociológus Cso MJONG-RE sem említette a környék ipari múltját, azt a társadalmi hely-

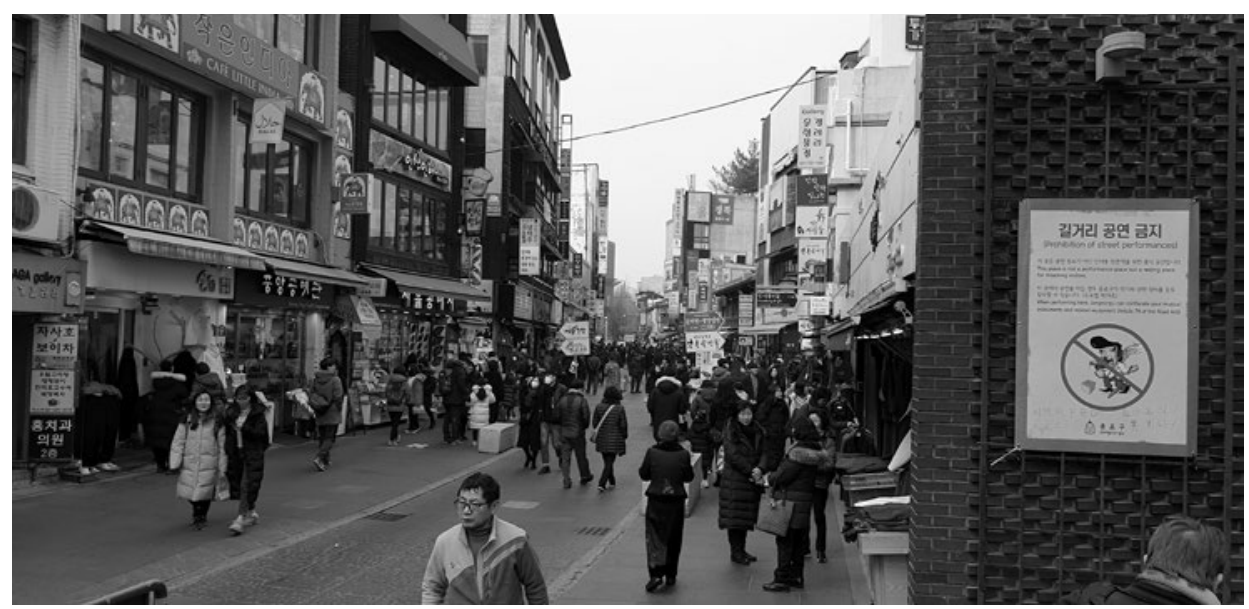

5. kép Cshonggjecshon hagyományos környéke ma sétálóutca és látványosság

Photo 5 The traditional neighbourhood of Cheonggyecheon is today pedestrian street and attraction Forrás/Source: Koudela, P. 
zetet, ami a háború utáni fél évszázadban jellemezte Cshonggjecshont. Ha beszélt is valaki a munkásokról, akik ott laktak, csupán a szép környék leromlásának, slummá válásának és a természet szégyentelen kizsákmányolásának részeseiként említette őket. „Városi szemétláda" - jellemezte a híres írónő, PAK KJONG-I; metángőzös, koszos, zsúfolt és élhetetlen hangzottak az általános jelzők a környékről az ezredfordulón. Mindez egybecseng az ipari növekedés áldozatával, a természetes környezet feladásával az önző gazdasági érdekért cserébe. A klisé, amit felsoroltunk, kísértetiesen emlékeztet a 19. század és a századforduló európai és amerikai nagyvárosokról alkotott képére, arra a negatív, egészségtelen környezetre, amit talán legékesebben EBENEZER HowARD reformterve ellenpontozott.

Pedig Cshonggjecshonban egymillió fiatal munkás találta meg a szerencséjét, akik az ország legkülönbözőbb pontjairól érkeztek. Ugyan sokszor semmilyen eszköztől nem riadtak vissza, származásuk és iskolázottságuk alapján semmilyen előítélet vagy diszkrimináció nem érte őket. Az ott élők beszámolói alapján a környék inkább emlékeztetett egy hangyavárra, ahol a munkások az ország gazdaságát szorgosan építik (JuN, H-U. et al. 2004). Cshonggjecshon felújításakor az itt múködő vállalatok nagy részét egy Szöul délkeleti részén újonnan épített üzleti központba, a Garden 5-ba költöztették, ez a döntés azonban nem vette figyelembe a hely sajátosságainak jelentőségét, az évtizedek alatt kiépült szoros gazdasági hálózatot, a környező ipari negyedekbe való beágyazottságot (SzONG, T-J. 2001). Cshonggjecshon dzsentrifikációja ugyanis közvetett társadalmi és közvetlen gazdasági költséget keltett a szomszédos területeken múködő vállalkozások számára (LIM, H. et al. 2013). A szomszédos területen élők és az ott múködő vállalatok szükségletei nem változtak, így az elköltöztetett vállalkozások és szolgáltatások helyett újakat kellett keresni, sokszor a korábbinál jóval messzebb. A meglévő gazdasági és társadalmi kapcsolatok egy részét egyáltalán nem sikerült pótolni, ami anyagi és társadalmi terhet rótt a szomszédos területekre. Mindezek eredményeképpen nem csupán a helyben létrejött gazdasági társulásokat hozták nehéz helyzetbe, hanem a tágabb térség múködésében is jelentôs változást okozott a felújítás. Ezekről a költségekről nemigen beszéltek, még becslés sincsen rá.

\section{Következtetések}

Cshonggjecshon revitalizációja és az azt követő dzsentrifikáció számos kritikát kapott, melyek többsége arra vonatkozott, hogy az ökológiai és a történeti helyreállítás miért volt eleve kudarcra ítélve vagy miért lett a döntések sorozatának eredményeképpen sikertelen. Tanulmányunkban a dzsentrifikáció negatív gazdasági és társadalmi hatásaként azt is számításba vettük, hogy a környék évtizedek alatt kiépült gazdasági kapcsolatrendszerének felbomlását, a részben átláthatatlan kis- és mikrovállalkozásokra épülő munkaerőpiacokat és szolgáltatást nemcsak a közvetlen, hanem a tágabb környezet is megsínylette.

A kritikai szemlélet, különösen PAK VONSZUN polgármesterré választása kapcsán, a városvezetés politikai irányváltásával élénkült fel, ami arra utal, hogy az állami, illetve városi szerepvállalásnak a jelentése is fontos elem a projekt megítélésekor, mégpedig nem csupán annak aktív résztvevőként való megítélésében, hanem a hatások értelmezése szemléleti háttereként is. Vagyis annak megítélése, hogy sikeres volt-e, illetve milyen mértékben volt sikeres egy városrehabilitáció, hogy miként értelmezhető az annak hatására lezajló dzsentrifikáció, nem értékmentes. Ha a városkép fejlesztésére, a turisztikai iparág növekedésére és az ebből származó bevételekre helyezzük a hangsúlyt, kiegészítve további fejlesztésekkel a város peremterületén, akkor egyértelmúen pozitív az összkép. Ha a helyi közösségek autonómiáját, a történeti eredetiséget és a patak spirituális hitelességét - ne feledjük, hogy tárgyak, természeti képződmények animista felfogása és spirituális jelen- 
tősége Kelet-Ázsiában nagyobb, mint nyugaton -, illetve a város szerves fejlődését állítjuk középpontba, akkor Cshonggjecshon revitalizációjának sikere kétséges.

Az így felvázolt szemléleti különbség azonban nagy vonalakban azonos a nyugati nagyvárosokban a városfejlesztés és az azt érő kritikák között az ötvenes-hatvanas években kibontakozott ellentéttel. Ha tehát a fejlesztő állam pragmatikusnak tekintett sajátos szerepvállalását értékeljük, a sajátos kelet-ázsiai kontextus jelentősége, szerepe nem általánosítható, nem tekinthető vezérelvnek, sokkal inkább rejlik olyan részletekben, mint a természeti tárgyak spirituális megítélése. Mivel a Koreai-félszigetet 70\%-ban hegyek borítják, nem csoda, ha az évszázadok során mitikus vonzalom alakult ki irántuk az emberekben, sőt túlvilági erőt is tulajdonítanak nekik, így nem véletlen, hogy a természet iránti vágy kifejezéseként Szöulban az ezredfordulót követően viszonylag új divatként mesterséges hegyeket építettek a lakótelepek közepére; némelyik eléri a 20 métert és akár 2 millió dollárba is kerülhetett. Ebből is látszik, hogy ez elsősorban a tehetősebbek számára kínál természeti élményt a városi dzsungelben; az építéshez igyekeznek különleges köveket és bonszaiokat kiválogatni és az ország híres hegyeit leutánozni (Ko, S. 2019). A múhegyek spirituális energiát árasztanak, szerencsét és egészséget hoznak, építésük a fengshui hagyományát követi. A hagyományos esztétikai kategória koreai neve csinkjongszanszu, vagyis valódi, valóban látható tájkép, jelentése pedig a természet folyamatos megfigyelése és a természettel való harmónia. A szent hegyek másolatai tehát nem csupán az ingatlanok esztétikai és eladási értékét növelik, hanem lelki megnyugvást is nyújtanak a lakók számára. KIM SzUNGKU személyében már fotómúvész is van, aki az ilyen hegyek specialistája, és tekintve, hogy a húszas éveit maga is építkezéseken dolgozta végig, pontosan ismeri az építmények szerkezetét is. Ez utóbbi példa arra kíván rávilágítani, hogy Cshonggjecshon revitalizációjának, illetve a projekt sikerességének értelmezésében a sajátos kulturális közeg figyelembevétele is szükséges. Cshonggjecshon maga is egyféle másolata az eredeti természeti tájnak, így a mesterséges hegyekkel való párhuzamba állítása és népszerúsége a helyi lakosok közt indokolt.

Számos esetben felmerült már az a kérdés, hogy vajon a kelet-ázsiai nagyvárosok illeszkednek-e egy egységes elméleti keretrendszerbe. Az egymás rovására vagy segítségével, de mindenképpen egységes rendszerben alakuló centrumok és perifériák modelljében az önállóan centrummá váló kelet-ázsiai országok a nemzetközi modellek finomítását kívánják. A megkésett iparosodás, ami ezeket az országokat jellemezte, egészen más fejlődési útra terelte városaik fejlődését is, amiben az államnak, és Korea esetében a fóvárosnak is kiemelt szerep jutott. Mindez azonban magának a felülről szerveződő, egységes hierarchiába rendeződő modellnek az alkalmazhatóságát és univerzális jellegét is kérdésessé teszi. A város nem csupán egyénekből, családokból vagy szomszédságokból áll, helyzetének meghatározásakor a történeti és a regionális sajátosságok legalább annyira meghatározók, mint a nemzeti szintû, de nem kormányzati szereplőkhöz fúződő viszonyaik (HILL, R.-KIM, W. 2000; HiLL, R. 2004).

\section{Összefoglalás}

Szöul dzsentrifikációja, a belváros szegénynegyedeinek felszámolása és magasépületekkel történő helyettesítése már az 1920-as években megkezdődött, így Cshonggjecshon tulajdonképpen csak egy folyamat végső állomásának tekinthető. A hetvenes évek átalakítása a nyomornegyed ledózerolásával indult meg, majd ezt követte a rekonstrukció. A hajdani negyedből mindössze egy 2005-ben nyílt múzeum maradt meg, amelyben fényképek, újságok és a viskók modelljei emlékeztetnek itt a rosszhírú múltra. A hálózatok felszámo- 
lása ismert példákat juttat eszünkbe: hasonló jelenséget láttunk a hatvanas évek amerikai nagyvárosaiban, és számtalan kutatás foglalkozott a dzsentrifikáció társadalmi hatásaival Magyarországon is (ENYEDI Gy. 2007). A hatvanas években az ilyen városrészek lebontásában a helyi közösségek és a társadalmi tőke rombolását látták a szociológusok, éppen azt a kritikát fogalmazták meg, mint amit SzONG, T-J.tett Cshonggjecshon rekonstrukciója kapcsán. Egyik helyen sem a városban, városrészben élők, hanem a városvezetés elképzelése határozta meg a fejlődés irányát, ami a város egészének gazdasági és esztétikai jobbá tételét célozta.

Szöul és az ország gazdaságirányításának a hetvenes évek óta a gazdasági növekedés a központi eleme. A kilencvenes évektől azonban egyre hangsúlyosabbá vált a helyi szintú fejlesztés, s a 2002-es polgármester-választások eredményeképpen ez egyre több programban valósult meg. Közülük szimbolikus és politikai jelentősége miatt kiemelkedik Cshonggjecshon és környékének rehabilitációja, ám az elemzések idővel kimutatták ennek káros hatását is a belváros társadalmára és a lokális gazdaságára. A 2011-es választásokat követően felerősödtek a társadalomkritikai szempontok. A rehabilitációt követő dzsentrifikáció a folyamatot tárgyaló tanulmányok megállapításaival szemben a nyugati nagyvárosokhoz hasonló eredményekkel járt Szöulban is. A projekt során és azt követően napvilágot látott elemzések rendre az ökológiai problémákkal, a történeti hitelesség kérdésével foglalkoznak, és a neoliberális gazdaságpolitikai környezet sajátos kelet-ázsiai jellegét hangsúlyozzák. Azonban - mint fentebb erre rámutattunk - minden sajátossága ellenére a Szöulban zajló dzsentrifikáció gazdasági-társadalmi jellege nem különbözik alapvetően más, nyugati nagyvárosoktól, amiben viszont eltér, az a kulturális környezet. Ez utóbbi figyelembevétele azonban ismét pozitív irányba billenti a revitalizáció hatásának mérlegét.

Koudela PÁL

Kodolányi János Egyetem, Budapest

pkoudela@yahoo.com

\section{IRODALOM}

AP: Ex-President Lee Myung-bak gets 15-year jail term over corruption. - The Korea Times, 2018. október 5. http://www.koreatimes.co.kr/www/nation/2018/10/251_256505.html (letöltve: 2020.03.14.)

AUGE M. 1995: Non-places: introduction to an anthropology of supermodernity. - Verso, New York. 99 p.

ATKINSON, R. 2003: Introduction: misunderstood saviour or vengeful wrecker? The many meanings and problems of gentrification. - Urban Studies 40. 12. pp. 2343-2350.

BERÉNYI B. E. 2016: Dzsentrifikációkutatás a poszt-szocialista városokban - Merre tovább? - Földrajzi Közlemények 140. 3. pp. 204-215.

Bond, L. 1991: Gender divisions and gentrification: a critique. - Transactions of the Institute of British Geographers 162. pp. 190-198.

CAstells, M. 1983: The city and the grassroots. - Edward Arnold, London. 450 p.

CHO, M-H. 2010: Envisioning Seoul as a world city: the cultural politics of the Hong-Dae cultural district. - Asian Studies Review, 34. 3. pp. 329-347.

CHo, M-R. 2010: The politics of urban nature restoration. The case of Cheonggyecheon restoration in Seoul, Korea. - International Development Planning Review, 322. pp. 145-165.

CHо, M-R. 2018: Ethnic place-making in cosmopolis: the case of Yeonbeon Village in Seoul. - In: CABANNES, Y.-Douglass, M.-Padawangi, R. (szerk.): Cities in Asia by and for the people. Amsterdam University Press. pp. 313-340.

CLAY, P. 1979: Neighborhood renewal: middle-class resettlement and incumbent upgrading in American neighborhoods. - Lexington Books, Lexington. 114. p. 
Cooke, T.-Denton, C. 2015: The suburbanization of poverty? An alternative perspective. - Urban Geography 36. 2. pp. 300-313.

CsAnÁdi G.-Csizmady A.-Kőszeghy L.-Tomay K. 2006: Belső Erzsébetvárosi rehabilitáció. - Tér és Társadalom 20. pp. 73-92.

Cso, M-R. (조명래) 2005: Cshonggjecshon helyreállításának eredményei és korlátai (청계천 복원의 성과와 한계). - A Koreai Építómérnök Társaság folyóirata (대한토목학회지) 5311.pp. 140-155.

CsONG, Sz-J. (정승열) 2014: Szöul erdő a város központjában (도심속 낙원 서울숲). http://www.ggilbo.com/news/articleView.html?idxno=185212\#0BJz (letöltve: 2020.03.14.)

CYRANOSKI, D. 2008: Korean waterway project gathers opposition. - Nature, News. 2008.03.25. https://www.nature.com/news/2008/080319/full/news.2008.679.html (letöltve: 2020.07.16.)

DOUCET, B. 2014: A process of change and a changing process: introduction to the special issue on contemporary gentrification. - Tijdschrift voor Economische en Sociale Geografie 105. 2. pp. 125-139.

EGEDY T. 2007: Városrehabilitáció és társadalom. - MTA FKI, Budapest. 305. p.

ENYEDI GY. (szerk.): A történelmi városközpontok átalakulásának társadalmi hatásai. (Magyarország az ezredfordulón: múhelytanulmányok). - MTA Társadalomkutató Központ, Budapest. 320. p.

FLORIDA, R. 2002: The rise of the creative class. - Basic Books, New York. 512 p.

GANs, H. 1962: The urban villagers: group and class in the life of Italian-Americans. - Free Press, New York. 367.p.

Gross, M. 2002: New natures and old science: hands-on practice and academic research in ecological restoration. - Science Studies 152. pp. 17-35.

GRoss, M. 2003: Inventing nature: ecological restoration by public experiments. - Lexington Books, Lanham. 240.p.

Gross, M. 2005: Ecological restoration as a real-world experiment: designing robust implementation strategies in an urban environment. - Public Understanding of Science 14. 3. pp. 269-284.

HALl, P. 1971: Spatial structure of metropolitan England and Wales. - In: CHISHOLM, M.-MANNERS, G. (szerk.): Spatial policy problems of the British economy. Cambridge University Press, Cambridge, pp. 96-125.

HARRISON, S.-JACOBS, A. 2016: Gentrification and the heterogeneous city: finding a role for design. - The Plan. 1. 2. pp. 239-259.

Hedin, K.-Clark, E.-Lundholm, E.-Malmberg, G. 2012: Neoliberalization of housing in Sweden: gentrification, filtering, and social polarization. - Annals of the Association of American Geographers 102. 2. pp. 443-463.

Henig, J. R. 1984: Gentrification and displacement of the elderly: an empirical analysis. - In: PALEN, J. J.-LONDON, B. (szerk.): Gentrification, displacement, and neighborhood revitalization. State University of New York Press, New York. pp. 170-184.

HiLl, R. C.-KIM, J. W. 2000: Global cities and developmental states: New York, Tokyo and Seoul. - Urban Studies 37. 12. pp. 2167-2195.

HILl, R. C. 2004: Cities and nested hierarchies. - International Social Science Journal 56. 181. pp. 373-384.

IVAKHIV, A. 1997: Ecocultural critical theory and ecocultural studies: contexts and research directions. - Conference on Cultures and Environments: on Cultural Environmental Studies. American Studies Program, Washington State University, June 20-22 1997. http://www.uvm.edu/ aivakhiv/eco_cult.htm (letöltve: 2020. 07. 17.)

JACOBS, J. 1961: The death and life of great American cities. - Vintage Books, New York. 458 p.

JENSEN, R. 1999: The dream society: how the coming shift from information to imagination will transform your business. - McGraw-Hill Education, New York. 242 p.

JEON, C.-KANG, K. 2019: Restoring and Re-RestoringtheCheonggyecheon: Nature, Technology, and History in Seoul, South Korea. - EnvironmentalHistory, 24. 4. pp. 736-765.

Johnson, C. 1982: MITI and the Japanese Miracle. - Stanford University Press, Stanford. 393 p.

JUN H-U. (윤홍은) et. al. 2004: Az utolsó tér: feljegyzések a Cshonggjecshonban élók életéből (마지막 공간: 청계천 사람들 의 삶 의 기록. 서울: 삶이보이는창). - Az élet ablaka (Ablak az életre), Szöul (삶창[삶이보이는창]). 419 p.

KAVANAGH, L.-LEE, D.-PRYCE, G. 2016: Is poverty decentralizing? Quantifying uncertainty in the decentralization of urban poverty. - Annals of the American Association of Geographers 106. 6. pp. 1286-1298.

KERSTEIN, R. 1990: Stage models of gentrification: an examination. - Urban Affairs Quarterly 25.4. pp. 620-639.

KHAN, S.-KHAN, M.-AN, S. K. 2019: Response to urban challenges by global cities within developmental states: the case of Tokyo and Seoul. - International Journal of Management and Economics 5. 4. pp. 369-390.

KIM, J.,-KIL, H. K. 2019: How Seoul, South Korea is reviving an old downtown district while preserving its history. - Brookings, 2019.10.24.

https://www.brookings.edu/blog/the-avenue/2019/10/24/how-seoul-south-korea-is-reviving-an-old-downtown-district-while-preserving-its-history/ (letöltve: 2020.07.16.)

Ko, S. 2019: Photographer captures Seoul's artificial 'mountains'. - CNN, 2019.11.07. https://edition.cnn.com/style/article/seoul-fake-mountain-photographer/index.html (letöltve: 2020.06.11.) 
KovÁcs Z.-EgEdy T.-SzABó B. 2011: A kreatív gazdaság földrajzi jellemzői Magyarországon. - Tér és Társadalom 25. 1. pp. 42-62.

Kurniawan, M. 2016: Dari Cheonggye ke Ciliwung. - Kompas.com 2016.10.04. https://travel.kompas.com/read/2016/10/04/203200427/dari.cheonggye.ke.ciliwung?page=all (letöltve: 2020.07.16.)

KwON, Y.-JoO, SH.-HAN, S.-PARK, CH. 2017: Mapping the distribution pattern of gentrification near urban parks in the case of Gyeongui Line Forest Park, Seoul, Korea. - Sustainability 9. 2. pp. 231-948.

LEE, S. Y. 2018: Cities for profit: Profit-driven gentrification in Seoul, South Korea. - Urban Studies 55. 12. pp. 2603-2617.

LeE, Y-S.-ShIN, H. R. 2012: Negotiating the polycentric city-region. Developmental state politics of new town development in the Seoul Capital Region. - Urban Studies, 49. 6. pp. 1333-1355.

LEES, L. 2000: A reappraisal of gentrification: towards a 'geography of gentrification'. - Progress in Human Geography 24. 3. pp. 389-408.

LEES, L. 2012: The geography of gentrification: Thinking through comparative urbanism. - Progress in Human Geography 36. 2. pp. 155-171.

LeES, L.-Slater, T.-WyLy, E. K. (szerk.) 2010: The gentrification reader. - Routledge, London. 648. p.

LEY, D. 2003: Artists, aestheticisation and the field of gentrification. - Urban Studies 412. pp. 2527-2544.

LiM, H.-Kim, J.-PotTER, C.-BAE, W. 2013: Urban regeneration and gentrification: Land use impacts of the Cheonggye Stream Restoration Project on the Seoul's central business district. - Habitat International 39. pp. 192-200.

Mele, C. 2000: Selling the Lower East Side: real estate, culture and resistance in New York City. - University of Minneapolis Press, Minneapolis. 408 p.

NAGY E.-IzSÁK É. 2017: A városi gazdaság - (újra)értelmezési lehetőségek a gazdaságföldrajz oktatásához. - Földrajzi közlemények 141. 3. pp. 246-253.

PAK Sz-H. (박승환) 2008: 21. századi többcélú projekt az ember és a természet, a munka és a pihenés harmóniájáért (인간과 자연, 일터와 심터가 어우러지는 21세기 다목적 프로젝트). - A Koreai Mérnök Szövetség folyóirata (기술사) 412.pp. 40-44.

Pamuk, A. 2005: Gentrification. - In CAVES, R. W. (szerk.): Encyclopedia of the city. Routledge, London. pp. 296-298.

PARK, J. 2019: Neoliberalism meets "Gangnam Style": vernacular private sector and large urban developments in Seoul. - Urban Planning 4. 4. pp. 62-72.

PECK, J. 2005: Struggling with the creative class. - International Journal of Urban and Regional Research 29. 4. pp. 740-770.

Perez, G. 2004: The near Northwest Side story: migration, displacement, and Puerto Rican families. - University of California Press, Berkeley. 290 p.

RANDOLPH, B.-TICE, A. 2014: Suburbanizing disadvantage in Australian cities: sociospatial change in an era of neoliberalism. - Journal of Urban Affairs 36. 1. pp. 384-399.

ReIs, L. F.-DA SiLva, R. L. M. 2016: Decadência e renascimento do Córrego Cheong-Gyeem Seul, Coreiado Sul: as circunstâncias socioeconômicas de seuabandonoe a motivação política por detrás projeto de restauração. - Urbe. Revista Brasileira de Gestão Urbana 81. pp. 113-129.

RÉPAT, P.-SÖDERSTRÖM, O.-PIgUET, E. 2010: Guest editorial - new forms of gentrification: issues and debates. - Population, Space and Place 16. 5. pp. 335-343.

RIEH, S-Y.-CHANG, J. 2018: Seoul, South Korea: dismantling a highway - Cheonggyecheon Restoration Project. - In: Darchen, S.-SeArle, G. (szerk.): Global planning innovations for urban sustainability. Routledge, Abingdon. pp. 121-135.

SAGER, T. 2011: Neo-liberal urban planning policies: a literature survey 1990-2010. - Progress in Planning 76. pp. 147-199.

SHAw, K. 2005: Local limits to gentrification: implications for a new urban policy. - In: ATKINSON, R.-BRIDGE, G. (szerk.): Gentrification in a global context: the new urban colonialism. Housing and Society series. Routledge, London. pp. 172-188.

SHAw, K. 2008: Gentrification: what it is, why it is, and what can be done about it. - Geography Compass 2 . 5. pp. 1697-1728.

SHIN, H. B. 2009: Property-based redevelopment and gentrification: The case of Seoul, South Korea.-Geoforum 40. 5. pp. 906-917.

SHIN, H. B.-KIM, S-H. 2015: The developmental state, speculative urbanisation and the politics of displacement in gentrifying Seoul. - Urban Studies special issue: Locating gentrification in East Asia. pp. 1-20

SMith, D. P.-ButLer, T. 2007: Conceptualising the sociospatial diversity of gentrification: 'to boldly go' into contemporary gentrified spaces, the 'final frontier'? - Environment and Planning A 39. 1. pp. 2-9.

Smith, N. 2002: New globalism, new urbanism: gentrification as global urban strategy. - Antipode 34. 3. pp. 427-450. 
SzONG, T-J. (송도영) 2001: Cshonggjecshon szerszámipar-hálózatának kialakulása (청계천 공구상가의 형성과 일 상적 관계망). PhD-értekezés. Kutatási sorozat 12. (연구총서12). Szöul Intézet, Szöul (서울학연구소).

TOMAY K. 2006: Slumosodás és városrehabilitáció Budapesten. - Tér és Társadalom 20. 1. pp. 93-107.

VAn DEN Berg, L.-Burns, L. S.-KlaAssen, L. H. (szerk.) 1987: Spatial cycles (Studies in spatial analysis). - Gower, Aldershot. 277 p.

Wyly, E. K.-HAMmel, D. J. 2005: Mapping neo-liberal American urbanism. - In: AtKInSON, R.-BRIDGE, G. (szerk.): Gentrification in a global context: the new urban colonialism. (Housing and Society series). Routledge, London. pp. 18-38.

ZuKIN, S. 1987: Gentrification: culture and capital in the urban core. - Annual Review of Sociology 131. pp. 129-147.

Zukin, S. 1991: Landscapes of power: from Detroit to Disneyworld. - University of California Press, Berkeley. $338 \mathrm{p}$.

ZuKIN, S. 1995: The cultures of cities. - Wiley-Blackwell, Malden. 338 p. 


\title{
MAGYARORSZÁG TÉRINFORMATIKAI ALAPÚ GYORSFORGALMI ÁTJÁRHATÓSÁGI VIZSGÁLATA AZ ELEKTROMOBILITÁS SZEMPONTJÁBÓL - HELYZETKÉP ÉS FEJLESZTÉSI LEHETÓSÉGEK
}

\author{
SOHA TAMÁS - NÉMETH IZABELLA - MUNKÁCSY BÉLA \\ GIS-BASED CONNECTIVITY ANALYSIS FROM THE PERSPECTIVE OF E-MOBILITY \\ ON HUNGARIAN MOTORWAYS \\ - CURRENT STATUS AND POSSIBLE DEVELOPEMENTS
}

\begin{abstract}
In the context of this research, two aspects, namely coverage and linear availability, have been examined for the possibility of quick charging of battery-powered electric vehicles in Hungary, focusing on national connectivity. It has been shown that the density of quick chargers is uneven; that is, they are present in the inner cities at a higher rate than along motorways for long-distance transport. The study carried out comparative analyses based on two previously published concepts (E.ON-MOL and BME KKT) and a dedicated methodology (ELTE KTF) using the potential charging sites outlined therein. Modelling has shown that the electric car charging possibilities available along the highways are limited. The investigation suggests that the strategic objective should not be to establish a charging network for national connectivity, since only $5 \%$ of the charging stations are currently located in the immediate vicinity of motorways and only half of which are quick chargers.
\end{abstract}

Keywords: battery-powered electric vehicles; quick charging; spatial optimisation; connectivity; Hungary

\section{Bevezetés}

Az energiarendszer ma megmaradt természeti eróforrások egyik legnagyobb fogyasztója, illetve lokális és globális környezetünk legjelentősebb szennyezője. Napjainkban a szektor gyökeres átalakulása folyik, ennek számos lényegi eleme közül kiemelkedik a terhelés csökkentésének szándéka. Erre kézenfekvő megoldás a tisztábban felhasználható megújuló energiaforrásokra való átállás és a villamos energia egyre általánosabbá válása az energiaszolgáltatások minden területén, így a hő- és a közlekedési energetika vonatkozásában is. Éppen tíz esztendeje, 2010-ben indult meg az első, nagy szériában értékesített elektromos autómodell, a Nissan Leaf gyártása. Ez azt is jelenti, hogy tíz éve lényegében még nem létezett töltési infrastruktúra sem. Hazánkban például ugyancsak 2010-ben telepítették az első ilyen állomást.

Napjainkra a töltôhálózat váza kialakult, és az elektromos autók, illetve az ezekkel párhuzamosan fejlődő, lényegesen alacsonyabb környezetterhelésű villamosáram-termelő technológiák (fơként szélerőmúvek és napelemek) révén radikális javulást érhetünk el az erőforrás-felhasználás hatékonyságában és a kibocsátás-csökkentésben egyaránt. Különösen jelentős javulás várható a nagy forgalmú, erősen szennyezett levegőjű városi terekben, ahol ráadásul számos más lehetőség is van a környezetterhelés csökkentésére (pl. a munkaszervezés optimalizálása, kerékpáros-központú településfejlesztés, a közösségi közlekedés minőségének javítása). Bár a városi terekben történő, jellemzően rövid távú utazások a megfelelő töltési infrastruktúra révén nem ütköznek akadályba, a nagyobb távolságok megtételérôl ugyanez már nem mondható el. Az elektromos személyautók hosszabb uta- 
zásokra való alkalmazása fóként akkumulátoraik kapacitásától, az üzemi körülményektől, illetve a töltési lehetôségektôl függ. Az egyre nagyobb és hatékonyabb akkumulátorok egyértelmúen hosszabb utazásokat tesznek lehetővé, azonban a megfelelő töltési infrastruktúra ugyanilyen súllyal kell, hogy szerepeljen az elektromobilitás (e-mobilitás) fejlesztése során. Amíg a múszaki fejlesztés elsősorban a személyautókat gyártó vállalatok mérnökeinek feladata, addig az infrastruktúra-fejlesztés az adott földrajzi terület döntéshozóira és az őket támogató területfejlesztési szakemberekre hárul. Ez utóbbi kapcsán törekedni kell arra, hogy megfelelő töltőhálózat jöjjön létre, amely a szakirodalomban ,hatótáv-aggodalom”-nak (range anxiety) nevezett jelenséget háttérbe szorítva megteremti az ország átjárhatóságának műszaki feltételeit (PEVEC, D. et al. 2020). Ennek kulcsfontosságú eleme a gyorsforgalmi utak mentén kiépülő, nagyobb távolságok biztonságos megtételét lehetővé tevő, gyors, és minden felhasználó számára garantált hozzáférést biztosító, megfizethető szolgáltatást kínáló töltési infrastruktúra.

A kulcskérdés az, hogy milyen döntéshozói szinteken, mikor ismerik fel, hogy az „energiaforradalom" megvalósítása, és ezen belül (többek között) a közlekedési szektor fenntarthatóvá tétele elkerülhetetlen. A 2019 decemberében útjára indított „European Green Deal” arra utal, hogy az Európai Unió vezetői részéről ez a felismerés már megtörtént. Ambiciózus célként az „első klímasemleges kontinens” létrehozását tűzték ki 30 éves időtávlatban, amelyben a fenntartható mobilitás is lényeges szerepet kap (Európa Tanács 2019). Dánia felelős kormánya - magyar szemmel - egészen elképesztő terveket fogalmazott meg nemzeti energia- és klímatervében, hiszen már 2030-ra 109\%-os megújulóenergia-részarányt tervezett a villamosenergia-termelésben. Ugyanezzel a céldátummal szerepel a tervben a belsóégésú motorral szerelt gépjármúvek dániai forgalmazásának megszüntetése (DMCEU 2019), ami pedig azt is feltételezi, hogy sok tekintetben még korlátozott használhatóságukat sikerül jelentôsen javítani.

Jelen kutatás célja, hogy elérhetőségi vizsgálatokon keresztül feltárja, milyen módon befolyásolja hazánkban az elektromos autózás elterjedését a jelenlegi töltési infrastruktúra, különös tekintettel a leggyorsabb töltési lehetőséget kínáló villámtöltésre, illetve összehasonlítja a töltőpontok elhelyezését célzó fejlesztési javaslatok hatékonyságát.

\section{Az elektromosautó-töltőállomások telepítését vizsgáló kutatások áttekintése}

A témával foglalkozó nemzetközi szakirodalom már a technológia megjelenésétôl kezdve, többféle szempontból vizsgálja az e-mobilitást kiszolgáló infrastruktúrához kapcsolódó problémakört. HoDGSON, M. J. (1990) FCLM- (Flow Capturing Facility Location Models) modellje számos tanulmány alapját képezte. A szerző a vonal menti igényt kiszolgáló létesítmények elhelyezésének lehetőségeit modellezte, megalapozta a szakaszorientált telepítési koncepciót, ezáltal módszertana a potenciális töltőállomások telepítésének optimalizálásában alapvetô kiindulóponttá vált. KuBY, M.-LiM, S. (2004) is a FCLM-modellt egészítette ki az elektromos autók számára szükséges töltőállomásokkal. Elemzésükben az optimális helyszínek a járművek hatótávjától, az utazás hosszától és az úthálózat sűrűségétől függenek.

ALEGRE, S. et al. (2017) tanulmánya már új megközelítést kínál a töltőállomások tervezésére szolgáló szoftverek fejlesztésében. A korábbi vizsgálatoktól eltéróen az elektromos jármúveket is indikátornak tekintették és a Matlab/Simulink segítségével modellezték is teljesítményüket. A GIS-alapú szimuláció során figyelembe vették az autó aerodinamikáját, tömegét, az akkumulátor kapacitását, a vezetési módot, az időjárás lehetséges változásait, az út típusát, valamint a töltők közötti távot - és ezek alapján tettek javaslatokat a töltőállomások telepítésére. 
A létesítmények térbeli elhelyezésének optimalizációjára számos kutatás alkalmaz térinformatikai eljárásokat, mind a területi lefedettség maximalizálása (FRADE, I. et al. 2011; CAPAR, I.-Kuby, M. 2012; Chung, S. H.-Kwon, C. 2015), mind pedig a közúthálózaton való elérhetőség és a töltőpontok számának minimalizálása szempontjából (SHAHRAKI, N. et al. 2015; HanabuSA, H.-Horiguchi, R. 2011). LiU, J. (2012) Peking és fokozottan urbanizált környezete példáján tárta fel a városi környezetben leginkább megfelelő töltési helyszíneket, rövidebb utazásokat feltételezve, valamint felhívta a figyelmet a 24 milliós lakosú város nagyléptékú elektromosautó-használatának a villamosenergia-rendszerre gyakorolt lehetséges hatásaira. Ezzel szemben HE, Y. et al. (2019) kifejezetten a hosszú távú utazásokra és az ezekkel összefüggésben levő villámtöltési lehetőségekre fókuszált a töltőpontok helyszín-optimalizációja során. DoNG, G. et al. (2019) tanulmányában hangsúlyosan jelennek meg a vizsgált terület népsûrúségi adatai és közúti forgalmi jellemzők.

Az ilyen jellegú hazai kutatások száma igazán szerény. GERSE J. (2020) statisztikai, illetve részben ezek hiányában nem hivatalos adatbázisokat használva mutatta be az elmúlt évek elektromobilitási fejlődését. Tanulmányában térképes megjelenítés segítségével mutatja be a nyilvános töltőpontok területi eloszlását és ezen infrastruktúra elérhetőségének nehézségeit. CsiszÁR Cs. és szerzőtársai (2018) országos léptékben, ugyancsak térinformatikai támogatással állapították meg a potenciális töltőállomás-helyszíneket. Fő céljukként nevezték meg, hogy olyan töltôhálózatra tegyenek javaslatot, amely biztosítja az ország átjárhatóságát - bár módszertanukat inkább országos lefedettségi vizsgálatként értelmezhetjük. Első lépésben megállapították a stratégiai helyszíneket, majd szúkítették a lehetőségeket a potenciális töltőállomásokra. Ezek kijelölése után kiszámolták a lefedettséget, végül meghatározták a szükséges töltőpontok számát az egyes töltőállomásokon. Azonban a potenciális töltőpontok köré vont egység sugarú körök mint ellátási területek kevésbé realisztikusak, mert az általuk ellátott területek úthálózatát gyakorlatilag utakkal homogén módon átszőtt síkbeli szövetnek tekinti. A tanulmány konklúziója, hogy töltőállomás-helyszíneket a jelentősebb forgalmú utak mellé szükséges telepíteni.

A témát érintő szakirodalom által bemutatott eredmények alapján konszenzus van abban, hogy a fớtvonalak mentén számos tényező befolyásolja a töltési igényt, ám ezek közül a forgalom nagysága és az elektromos autók hatótávolsága a legmeghatározóbb. Sok esetben a tanulmányok nem foglalkoznak a töltési idővel, pedig ez a tényező a hosszú távú utak megtétele szempontjából döntő fontosságú.

\section{Módszertan}

A felhasználói tapasztalatok alapján hazánkban a gyorsforgalmi utak mentén a hosszabb távú utak megtételéhez szükséges töltési lehetôségek hiányosan vannak jelen. A tanulmányozott szakirodalom alapján számos indikátort használhatunk fel ahhoz, hogy a lehető legpontosabban lehessen ábrázolni az aktuális helyzetet, azonban a töltési idő (gyorsés villámtöltő) és a térbeliség a legtöbb kutatástól eltérően kulcsfontosságú szempontként jelenik meg munkánk során. Fontos szempontként érvényesítettük, hogy a hosszú távolságokat minél gyorsabban és zökkenőmentesen lehessen megtenni, ezért csak az általánosan használható CHAdeMO (japán) és CCS (európai) szabvány szerint múködő villámtöltőkre (40 kW-nál nagyobb töltési teljesítmény) összpontosítottunk a modellezés során - ezek a nemzetközi szakirodalomban , quick charger”-ként jelennek meg, szemben az alacsonyabb teljesítményű „fast charger”-rel. A Tesla Supercharger és Ionity töltőállomásokat a vizsgálat során nem vettük figyelembe, mert ezek nem minden felhasználó számára elérhetők. 


\section{A jelenlegi EV átjárhatóság modellezése}

Egységes, állami kezelésú adatbázis hiányában a Mobiliti mobiltelefonos applikációja alapján készítettük el azt az adatbázist, amely tartalmazza a 2019. szeptember 12-ig telepített, összes nyilvános töltőállomás jellemzőit és pontos földrajzi pozícióját, tekintet nélkül a telepítést és üzemeltetést végzó piaci szereplőkre. A létrehozott adatbázis nem tartalmazza azonban a Budapest területén levő töltőket, hiszen országos viszonylatban kiemelkedő sűrûségük és lokális szolgáltatásuk miatt a kutatás szempontjából nem relevánsak. A vizsgálatok elvégzéséhez felhasználtuk továbbá az Open Street Map (OSM) Magyarországra vonatkozó közúthálózatának téradatait. Az egyes útszakaszok forgalmát a keresztmetszeti mértékadó óraforgalommal (MOF) definiáltuk (MK Nonprofit Zrt. 2018). A térinformatikai modellezés az ArcMap 10.2-es munkakörnyezetében történt, amelyhez a Network Analyst eszközcsomag Service Area opcióját alkalmaztuk az areális lefedettségi és lineáris elérhetôségi vizsgálatokhoz.

\section{Villámtöltési lehetôségek areális lefedettség-vizsgálata}

Az egyes villámtöltő állomások országos areális lefedettség-vizsgálatához a töltőállomásoktól távolodva 20 km-es, közúton értelmezett zónákat hoztunk létre. Mivel jelenleg a piacon lévő elektromos autók közül a hazánkban egyik leggyakoribb, átlagosnak tekinthető, második generációs, nettó $36 \mathrm{kWh}$-s akkumulátorral szerelt Nissan Leaf kedvező üzemi körülmények között elérhető hatótávolsága $260 \mathrm{~km}$, ezt tekintettük az elemzés során „maximális távolságnak”. Valós körülmények között ez a modell egy töltéssel 200-210 km megtételére alkalmas autópályán.

Ellentétben a pufferzónás ellátásiterület-kijelölés egységsugarú kör alapú zónáival, a Service Area eszköz pontosabb eredményt rajzol ki. A szoftver nemcsak közúton ábrázolja a határokat, hanem feltételezi, hogy a hálózatban felhasznált útszakaszok közötti üres térben szintén lehetnek alacsonyabb rendű, a vizsgálatban részt nem vevő utak. Így az egyes távolsági kategóriák a vizsgálatban résztvevő közúttal való metszéspontjai alapján végez térbeli interpolációt két szomszédos, egymáshoz közeli útszakasz közötti térrész kitöltésére. Az egyes villámtöltők körül kijelölhető, azonos távolsági értékű szomszédos zónákat összevontuk a realisztikusabb és egységes megjelenítés érdekében.

\section{A villámtöltési lehetôségek lineáris elérhetöségi vizsgálata}

A lineáris elérhetőségi vizsgálat esetében kifejezetten a gyorsforgalmi utakat és az azok mentén elérhető villámtöltőket vettük figyelembe, hogy a modellezés során az ország átjárhatósága kerüljön a vizsgálat középpontjába. A számításokhoz, illetve az eredmények ábrázolásához - az areális lefedettség vizsgálatával ellentétben - nem poligont, hanem vonalas megjelenítést alkalmaztunk, és szintén 20 km-es osztályközöket használva, a villámtöltési lehetőségektől való $260 \mathrm{~km}$-es elméleti maximális eljutási távolságot vettünk figyelembe.

A modell a kijelölt kiindulóponttól távolodva (figyelembe véve a menetirány szerinti két oldalt, vagyis az egyes útpályák egyirányúságát) a hálózat alapját képző autópályákra vetítve jelöli ki az elérhetô útszakaszt, egészen a meghatározott maximális távolságig. Amennyiben a hálózaton még a maximális távolság elérése előtt újabb töltőpontba ütközik, a kiindulási pontra vonatkozó szolgáltatási terület véget ér, és új útszakasz kijelölésébe kezd az új töltőpontot kezdőpontként felhasználva. Ha a modellezett személyautó indulási helyétôl $260 \mathrm{~km}$-en belül új töltőállomással találkozik, feltételezzük, hogy ott minden esetben él a töltési lehetôséggel annak érdekében, hogy az elméleti maximális hatótávolságát kihasználhassa. Ha a következő töltőpont 260 km-nél távolabb helyezkedik el, a szol- 
gáltatási terület véget ér, ami az akkumulátor lemerülésének felel meg. Fontos azonban megjegyezni, hogy a valóságban egy elektromos személyautó hatótávolságát több tényező befolyásolja, sûrûn telepített töltőállomások esetén pedig valószínútlen, hogy a jármú vezetôje minden alkalommal megáll az elérhető maximális akkumulátor-töltöttség fenntartása érdekében.

A lineáris vizsgálat során első körben kétféle modellezés készült, amelyek a teljesség igénye nélkül mutatják be a hosszú távú utazásokat lehetővé tevő hazai töltőtelepítési koncepciót, illetve - sokkal inkább - annak hiányosságait. Az egyik esetben elektromos személyautók Budapestről való indulását feltételeztük, az autópályákon a fővárostól minden esetben távolodva. Ennek alapján csak az útpályák kivezető oldalait, illetve a közvetlenül ezek pihenőiben üzemelő villámtöltők elhelyezkedését vettük figyelembe. A modellezés helyes múködése érdekében a meglévőkkel azonos tulajdonságúnak tekintett fiktív töltőpontokat jelöltünk ki az autópályák budapesti kezdőpontjain, feltételezve, hogy az elektromos autók teljes feltöltöttséggel indulnak útnak. Ebben az esetben azonban felmerül a kapcsolódó gyorsforgalmi utak szolgáltatási területeinek átfedési problémája. Ez leginkább az M0-s körgyúrú környezetében léphet fel, ahol a szomszédos autópályák le- és felhajtási lehetőségei miatt a szoftver által generált egyes „szolgáltatási területek” átfedésben lehetnek, ezért felülírhatják egymást, hibás értékeket eredményezve. A probléma feloldása érdekében a hálózat módosítására, vagyis bizonyos fel- és lehajtók csatlakozási lehetőségeinek megszüntetésére volt szükség.

Egy másik lineáris elérhetóségi vizsgálat során a modellezés rugalmasabb feltételekkel készült. Ebben az esetben a gyorsforgalmi utak $5 \mathrm{~km}$-es sugarán belüli területeken elhelyezkedő, meglévő villámtöltốk mindegyike részt vett a vizsgálatban, tekintet nélkül a kiindulási helyzetre és a menetirány szerinti oldalakra. A modell futtatása során nemcsak az autópályákról való letérés lehetősége volt adott, de még az azokat keresztező és csatlakozással rendelkező felüljárókon keresztül való visszafordulás is. Az így létrejövő, számtalan töltőállomás-elérési útvonalból fakadó ellátási területek átfedései miatt nem végeztük el a probléma kiküszöbölését célzó hálózatmódosítást. Mivel a releváns villámtöltők elemszáma az előző lineáris modellezéshez képest magasabb, az autópályák Budapestről induló kezdőpontjain nem alkalmaztunk fiktív töltőpontokat. Ehelyett az autópályáknak az országba belépő pontjaira, illetve az M3-as autópálya vásárosnaményi, jelenleg töltőhiányos elvégződéséhez helyeztünk fiktív villámtöltési pontokat. Az eljárás az areális lefedettségi vizsgálathoz hasonlítható, az eredmények pedig a gyorsforgalmi úthálózat egy véletlenszerúen választott pontja és a legközelebbi villámtöltési lehetőség közötti, közúton értelmezett távolságot adják meg.

\section{Hálózatbővítés esetén létrejövó átjárhatóság modellezése}

A jelenlegi gyorsforgalmi átjárhatóság vizsgálatán túl, potenciális, különböző szempontok szerint megvalósítható, a villámtöltő-infrastruktúrát érintő lehetséges fejlesztések modellezését is elvégeztük. Három olyan lehetőséget vizsgáltunk meg, amelyek más-más megközelítésből tesznek javaslatot a jövőben telepítendő villámtöltők helyszíni kijelölésére. Ezek között szerepel $a$ ) egy profitorientált versenypiaci szereplő (E.ON-MOL) koncepciója; $b$ ) egy tudományos megközelítésú, racionális tervezésen alapuló (CsISZÁR Cs. et al. 2018) koncepció, amelyre a továbbiakban BME KKT (Budapesti Múszaki és Gazdaságtudományi Egyetem, Közlekedésüzemi és Közlekedésgazdasági Tanszék) megnevezéssel hivatkozunk; valamint $c$ ) a két koncepció előnyeit ötvöző helyszínkijelölési eljárás, a továbbiakban ELTE KTF (Eötvös Loránd Tudományegyetem, Környezet- és Tájföldrajzi Tanszék), amelyet az előző kettő eredményeinek tanulságai alapján hoztunk létre. 


\section{Az E.ON-MOL bövítési terveinek vizsgálata}

Az E.ON Hungária Zrt., a MOL Nyrt. és a Nissan magyarországi leányvállalatának kooperációja keretében egy hozzávetőleg 150 km-es sûrúséggel telepített, univerzális villámtöltő-hálózatot építenének ki a jövőben az európai tranzitútvonalak mentén, közvetlenül a MOL-csoporthoz tartozó töltôállomás-gerinchálózaton. Feltételeztük, hogy a vállalat minden meglévő üzemanyagtöltő-állomásán villámtöltőket telepítenek, majd ezt a halmazt kiegészítettük az autópályákon már jelenleg is elérhető elektromos töltőállomásokkal. Ebben az esetben is alkalmaztunk fiktív töltôpontokat az autópályák kiindulópontjainál, azonban a vizsgálatot egy időben mind a két menetirányban elvégeztük. Ennek oka, hogy a legtöbb esetben (az Annahegyi és az Arrabonai pihenőhely kivételével) a MOL-csoporthoz tartozó benzinkutak párosan helyezkednek el az autópályák mentén.

\section{A BME KKT eredményeinek vizsgálata}

Tudomásunk szerint jelenleg csupán egyetlen ilyen jellegú tudományos publikáció született (Csiszár Cs. et al. 2018). E kutatás célja egy országos lefedettséget biztosító töltôhálózatra való javaslattétel, éppen emiatt nem a gyorsforgalmi utakon való hosszú távú közlekedés lehetôvé tétele volt a fó szempont. Ennek ellenére az eredmények vizsgálata az autópályákon nagy számban kijelölt töltőhelyszínek miatt indokolt. A kutatásban javasolt lehetséges töltőhelyszíneket az adatbázisba integráltuk, ezek közül az autópályákra javasolt 70-et vizsgáltuk meg az gyorsforgalmi úthálózat átjárhatóságának szempontjából. Az E.ON-MOL javaslatainak vizsgálatához hasonlóan fiktív töltőpontokat és a már meglévő töltőállomásokat is figyelembe vettük a modellezés során.

\section{Az ELTE KTF kutatási módszertan bemutatása}

A módszertan kidolgozása során az volt a célunk, hogy a fent bemutatott két villámtöltő-telepítési szemlélet metszeteként, komplex megközelítést alkalmazva hasznosítsuk azok kedvező tulajdonságait. Ezek alapján az alábbi három fő szempont alkalmazásával dolgoztuk ki a módszertant:

1. Az E.ON-MOL-koncepció a meglévő töltőállomás-infrastruktúrára - mint szolgáltatásokkal (étkezési lehetőség, mosdó stb.) rendelkező helyszínekre - alapoz. Ez a megközelítés (érthető üzletstratégiai okokból) csak a saját üzemanyagtöltóállomás-hálózat elemeit veszi figyelembe, illetve negligálja az adott útszakaszra jellemző közúti forgalom szerepét. Ezzel szemben a saját módszertanban az autópályák mentén elérhető, más szolgáltatók benzinkútjait is figyelembe vettük potenciális helyszínekként.

2. A BME KKT-kutatás már figyelembe veszi a várható gépjármúforgalmat, de azt az egyes települések lakosságszámából származtatja, és nem a gyorsforgalmi utak gépjármúforgalmi adatait használja kiindulásként. Ennek ellenére telepítési szempontként jelenik meg az egyes helyszínek szolgáltatási szintje is, ami valóban befolyásolhatja a várható kihasználtságot.

3. A két helyszínkijelölés közül azonban egyik sem veszi figyelembe a javasolt töltópontok között fennmaradó (az elektromos autók kisebb hatótávolsága miatt jelentkező), az elektromos töltóállomások szempontjából hiányos útszakaszokat.

A gyorsforgalmi utak mentén telepíthető töltőállomások optimális helyszíneinek meghatározásához kétkörös eljárást alkalmaztunk. Az első körben minden pihenőhely esetében meghatároztuk az autópálya adott oldalára vonatkozó MOF-értékeket (MK Nonprofit Zrt. 2018). A 707-től (Kántorjánosi pihenő, M3) 11073-ig (Csepel, M0) terjedő tartományt természetes törések alapján három csoportra osztottuk. Az alacsonyabb forgalmú szakaszok két csoportjában (MOF $\leq 5183)$ kijelöltük az benzinkúttal rendelkező összes pihenőt, illetve azokon kívül minden nagyobb forgalmú (MOF $\geq 5184)$ szakasz mentén lévő pihenőhelyet, 
még abban az esetben is, ha benzinkút vagy más szolgáltatás nem vehetô igénybe az adott helyszínen. Az így kiválasztott 99 helyszín kibővült a már jelenleg is meglévő (bár néhány esetben átfedésben levő) villámtöltők helyszíneivel, illetve az autópályák végére elhelyezett, ebben az esetben is alkalmazott fiktív töltőpontokkal. További 84 olyan helyszín van, amely az említett kritériumok egyikének sem felel meg, tehát az első körben nem került kiválasztásra. Az első körös kijelölés a fentebb ismertetett 1. és 2. szempontot ötvözi. Az elérhetőségi vizsgálat elvégzése után kirajzolódtak azok az útszakaszok, amelyek valamely kijelölt ponttól 50 km-nél nagyobb távolságra helyezkednek el.

E problémás szakaszok kiküszöbölését célozta meg a második körös helyszínkijelölés, amiben a 3. fó szempont jelenik meg. Az ilyen, első körből származó villámtöltôvel le nem fedett útszakaszokat megelőző közúton értelmezett legközelebbi pihenőhelyeket vettük számításba (7), tekintet nélkül az ott elérhető szolgáltatás minőségére. Ezeket az első körben kijelölt pihenőkkel összevonva, újból elvégeztük az elérhetőségi vizsgálatot az elektromos autóval nehezen elérhető, töltőhiányos útszakaszok hosszának csökkentése érdekében.

\section{Eredmények}

\section{Az elektromos töltőállomások infrastruktúrájának helyzete Magyarországon}

Az elhelyezkedés szempontjából jelentôs területi egyenlőtlenségek figyelhetôk meg: Nyugat-Magyarországon súrúbben vannak töltőállomások, a kelet-magyarországi térségben szerényebb az ellátottság. A megyeszékhelyeket tekintve viszonylag egyenlő az eloszlás, míg a városokban és a nagyobb településeken elszórtan állnak rendelkezésre töltőpontok. Két sűrúbb a hálózatú, kiemelt terület van az országban: Budapest és környéke (kifejezetten az M0-s autóút környezetében) és a Balaton térsége.

A töltők típusát tekintve, az országban döntően gyorstöltők állnak rendelkezésre, ami összhangban van az európai trendekkel. A vizsgálatban összesen 475 Budapesten kívüli, az elterjed csatlakozó-típusokkal használható nyilvános töltőpont szerepelt, ebből 369 gyors és 96 villámtöltó. A villámtöltők közül 52 található a gyorsforgalmi utak $5 \mathrm{~km}$-es körzetében, a közvetlenül az autópályák pihenőiben elhelyezett berendezések száma pedig nem több, mint 10.

Az elektromos autók száma 2020 májusára éppen meghaladta a 9 ezret. Érdekes adalék, hogy a PWC Magyarország (2013) elemzésének „realista” forgatókönyve 2020-ra hazánkban 25650 nyilvános töltóponttal és 45 ezer elektromos autóval számol (a „,peszszimista" forgatókönyv pedig 15675 töltővel és 27500 e-autóval). Ezek az előrejelzések jóval felülmúlják a tárgyévben rendelkezésre álló töltők számát még annak tudatában is, hogy az egyes töltőállomásokon rendszerint több töltőpont vagy csatlakozási lehetőség is rendelkezésre áll.

\section{Areális elérhetôség: villámtöltók országos lefedettsége}

A jelenlegi országos lefedettséget tekintve megfigyelhető, hogy a villámtöltők az autópályák és a főutak közelében nagyobb számban, sok esetben belterületen találhatók, ugyanakkor számos, még akár városi ranggal is rendelkező településen hiányoznak (1. ábra). A villámtöltők helyétôl számított $20 \mathrm{~km}$-en belülre eső területek az ország $28,2 \%$-át, míg a 20 és $40 \mathrm{~km}$ között fekvő területek a 45\%-át fedik le. A 40 és $80 \mathrm{~km}$-es távolságból elérhető területek összesen 26,15\%-ot foglalnak el, és a 80 km-nél távolabbi területek már csak 
kevesebb, mint 1\%-ban vannak jelen. A villámtöltőktől 100 km-nél nagyobb távolságban lévő területek az északkeleti határ mentén vannak elenyésző mértékben.

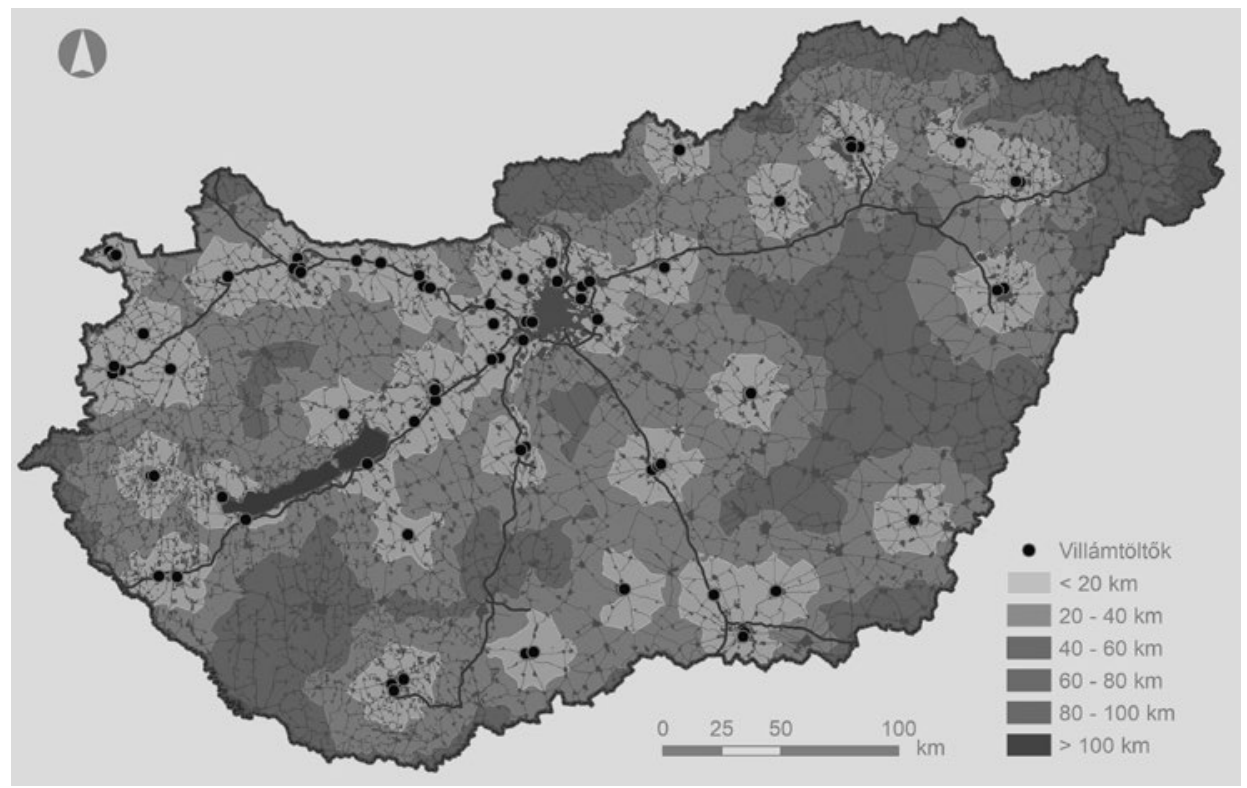

1. ábra Villámtöltók országos elérhetősége az areális lefedettség-vizsgálat alapján Figure 1 National connectivity of quick chargers according to the areal coverage analysis

\section{Lineáris elérhetöség: autópályákon közvetlenül elérhetö töltőállomások}

\section{Elérhetôség Budapestról indulva és távolodva}

Budapestről történő indulás esetén is modelleztük az elérhetőséget, azokat a töltőállomásokat figyelembe véve, amelyek a fơvárosból kivezetô sávban találhatók - ez jelenleg mindössze 3 villámtöltőt jelent (Gödölloon, Kajászón és Mocsán). Az autópályák budapesti kiindulópontjaira elhelyezett fiktív töltőpontoktól számított $60 \mathrm{~km}$-en belüli útszakaszok 42\%-át, a 60 és $120 \mathrm{~km}$ közöttiek 23\%-át, míg a 120 km-től $180 \mathrm{~km}$-ig tartó szakaszok $21 \%$-át adják a teljes úthossznak (2. ábra). Az ennél távolabbra esố útszakaszok (180-260 km) már kevésbé tekinthetők biztonságosan elérhetônek.

Az eredmények alapján kijelenthető, hogy egy tisztán elektromos meghajtású, középkategóriás személyautó az országon belül nagyobb távolságok megtételére jelen feltételek mellett nem alkalmas, mert ezt az infrastruktúra nem teszi lehetóvé.

\section{Autópályák közelében elérhető töltőállomások}

A pihenőkben elhelyezett töltóállomások hiányából származó elérhetőségi problémák nagymértékben csökkenhetnek, ha az autópályákhoz közeli töltőállomásokhoz való lehajtás, vagy a visszafordulás lehetőségét is figyelembe vesszük. Ez utóbbi miatt nem volt szükség az útirány meghatározására vagy bármely egyéb útvonal-választási megkötésre. A vizsgálatban 52 villámtöltő szerepelt, bár közülük mindössze 10 fekszik az autópályák mentén. Az esetek 40\%-ában a töltôhelyszínek az autópályák közelében fekvő, nagyobb városainkban találhatók, ezáltal több lehetőség áll rendelkezésre egy elektromos autó feltöltésére (3. ábra). 


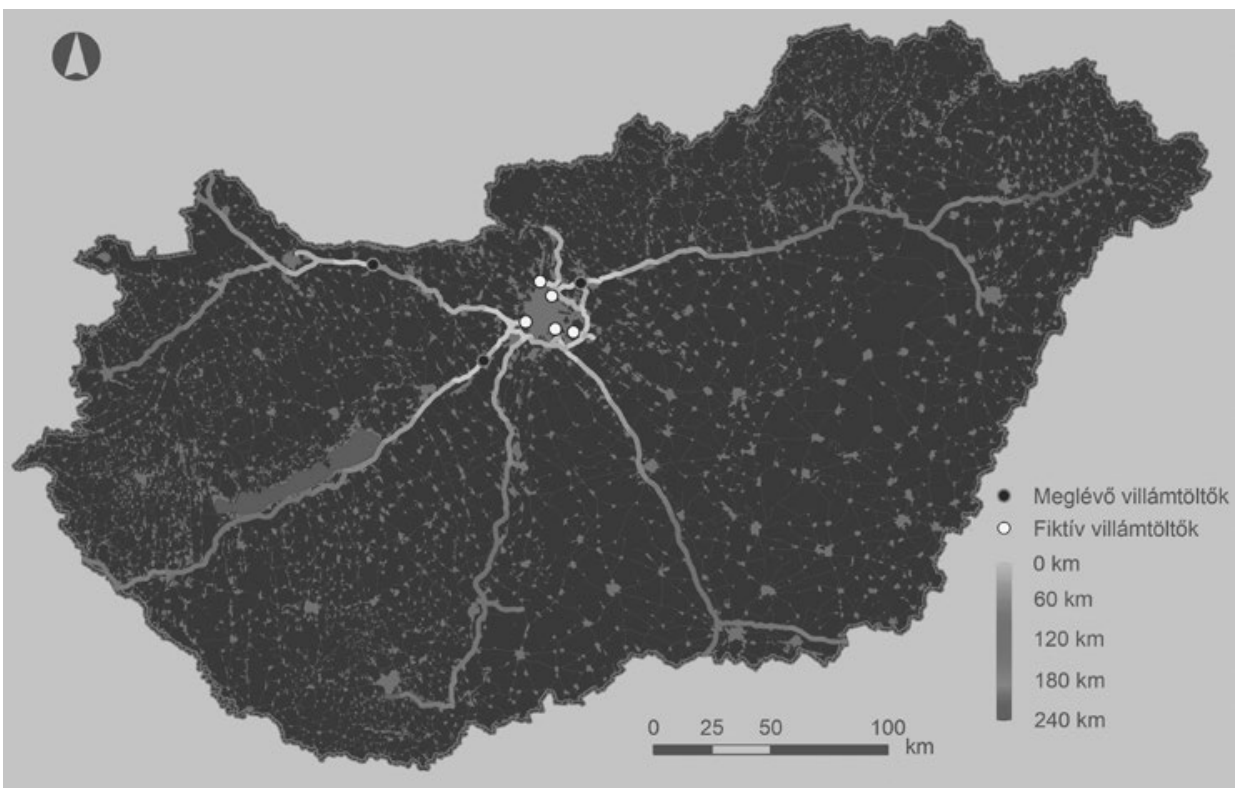

2. ábra Autópályák elérhetősége Budapestről indulva Figure 2 Highway accessibility from Budapest

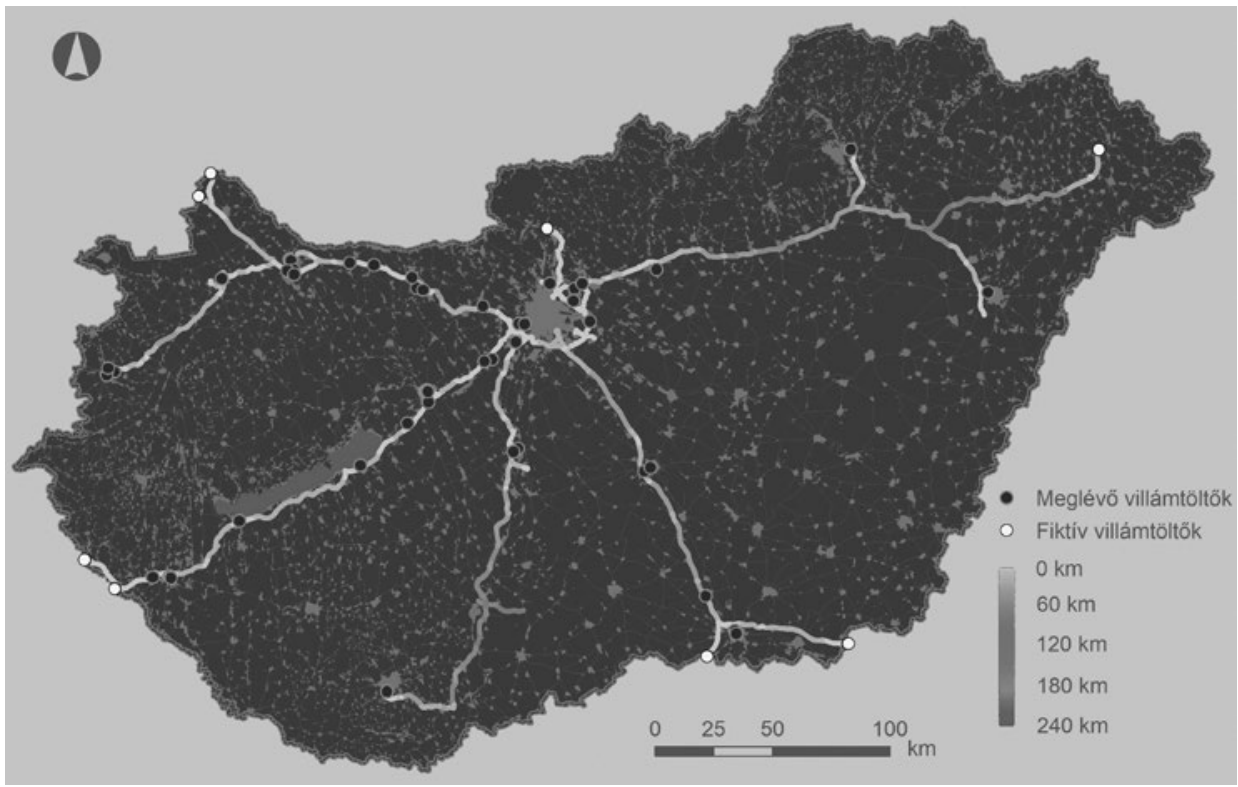

3. ábra Elérhetőség az autópályák 5 km-es körzetén belül levő villámtöltők használata esetén Figure 3 Quick charger accessibility in a $5 \mathrm{~km}$ area of highways

Az elemzés szerint az autópályák összes úthosszának 49\%-a az elektromos töltőállomásoktól számított 20 km-en, míg 29\%-a 20-40 km-en belül található, azonban ebbe 
beleértendők a távolabbi töltőponthoz való eljutáshoz szükséges rövidebb, összekötő útszakaszok. Ez alapján a modellezéshez felhasznált töltők elhelyezkedése már elegendő lenne az országos átjárhatóság szempontjából, bár ebben az esetben figyelembe kell venni, hogy az autópályáról való lehajtás többletidóbe és -energiába kerül, ami a hosszú távú közlekedés ellen hat.

\section{Hálózatbövités esetén létrejövő átjárhatóság}

\section{Az E.ON-MOL bövítési tervek vizsgálatának eredménye}

Az autópályák mentén üzemelő 34 MOL-töltőállomáson telepítendő, a már jelenleg is elérhetô villámtöltők, illetve az ezen utak kezdőpontjaira helyezett fiktív töltôpontokkal együtt 53 helyszín vett részt a modellezésben, aminek eredményeit a 4. ábra szemlélteti. A gyorsforgalmi utak vizsgálatban szereplő teljes hosszához képest $(2825 \mathrm{~km})$ a töltőpontoktól számított $20 \mathrm{~km}$-es távolságon belülre eső szakaszok 38\%-ot tesznek ki, míg a 20 és 40 km közöttiek 28,6\%-ban, a 40 és $60 \mathrm{~km}$ közötti szakaszok 18,6\%-ban részesednek a teljes úthosszból. Ez a három távolság-kategória $(0-20 ; 20-40 ; 40-60$ km) magába foglalja az autópályák teljes hosszának 85\%-át. Ennek értelmében az E.ON-MOL célkitűzésében szereplő potenciális töltőállomások megfelelő számban vannak jelen ahhoz, hogy az együttmúködésben megfogalmazott, kelet-közép-európai régió átjárhatóságának biztosítása legalább Magyarország esetében kivitelezhető legyen.

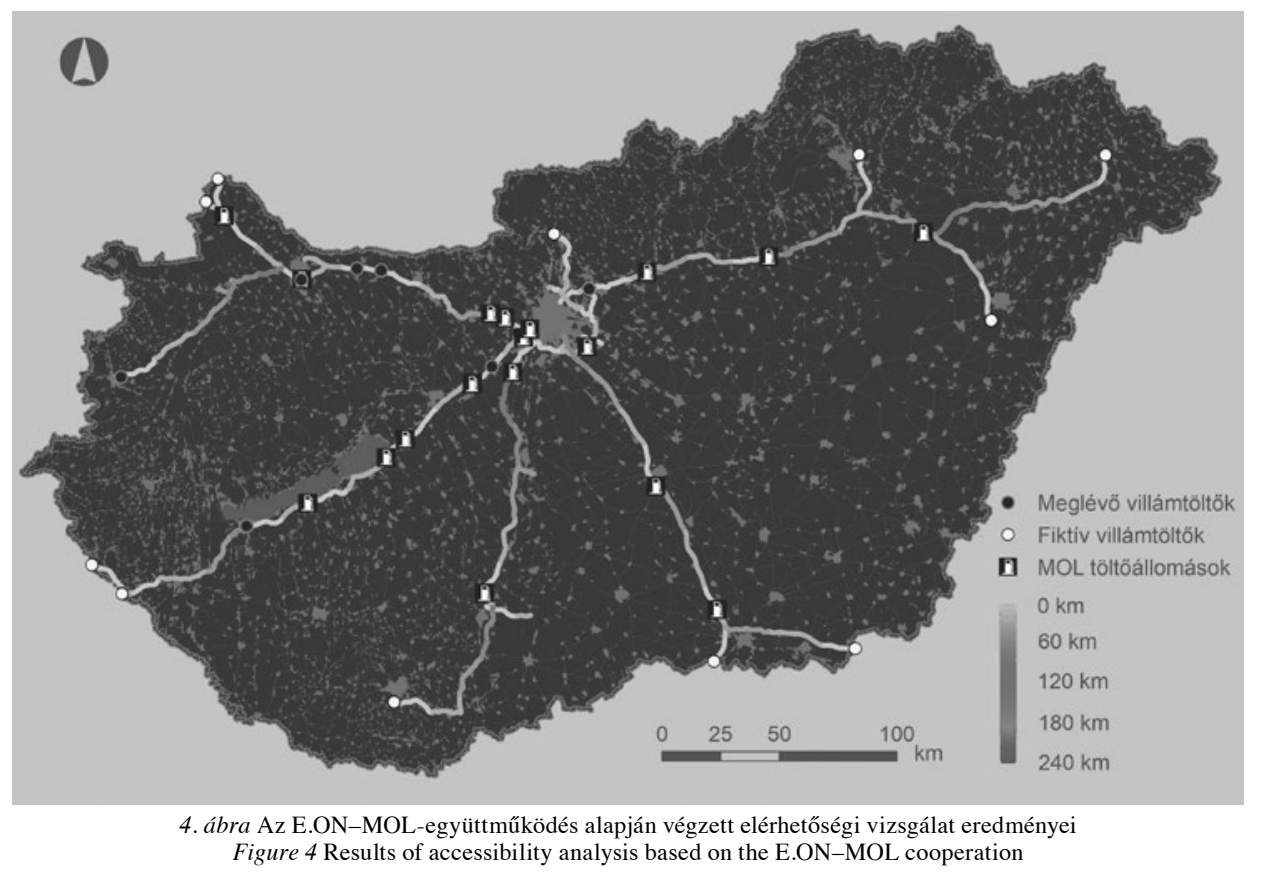

A MOL-pihenőhelyek azonban egyenlőtlen eloszlásban helyezkednek el az ország autópályáin: míg az M7-esen 10, addig az M6-os és M5-ös autópálya vonalán 4-4 pihenóhely áll rendelkezésre. Például az M6-os Budapest felé tartó vonalán, a Pécs közelébe helyezett fiktív töltôponttól indulva 90 km távolságra fekszik az első (Fácánkerti) MOL-töltőállomás, 
majd a következő, százhalombattai „Keresztúri pihenő” további 105 km-re. Ezzel szemben, az M7-es fóváros felől kivezető vonalán, a budaörsi MOL-benzinkút és a balatonkeresztúri villámtöltő közötti 160 km-es szakaszon 4 MOL-benzinkút és 1 már jelenleg is üzemelő elektromos töltőállomás található. Azonban Balatonkeresztúrtól a tornyiszentmiklósi határátkelőhelyig tartó $90 \mathrm{~km}$-es szakaszon - potenciális töltőállomás-befogadóként - nem áll rendelkezésre egyetlen egy MOL-töltőállomás sem.

Bár a MOL-töltőállomásokon telepítendő villámtöltők önmagukban is képesek lennének biztosítani a magyarországi tranzitútvonalak átjárhatóságát, a jövőben számos más szolgáltató hozzájárulása valószínúsíthető a töltóállomások széles körű elérhetôségéhez.

\section{A BME KKT-kutatás eredményeinek elemzése}

E részkutatás keretében a CsISZÁR Cs. et al. (2018) által javasolt 70 villámtöltő közül leválogattuk az autópályák mentén lévő 60 helyszínt, amelyek közül 4-ben már jelenleg is üzemel villámtöltő. A BME KKT által javasolt potenciális töltőállomás-helyszíneket kifejezetten a közúthálózat mentén lévő üzemanyagtöltő-állomásokra helyezték el. Ennek az az oka, hogy a kiegészítő szolgáltatások meglétét, emellett a villamosenergia-hálózat kiépítettségét is figyelembe vették, ezáltal a lehetséges helyszínek száma leszúkült a már meglévő pihenőhelyekre, különösen a benzinkutakra. Ezek alapján a magyarországi autópályák vonalán elérhető 82 üzemanyagtöltő-állomásból 58 helyszínre került potenciális töltőpont. Emellett a már szintén meglévő, de az általuk javasolt helyszínekkel nem egyező töltőket is felhasználtuk, ugyancsak a korábban alkalmazott fiktív töltőpontokkal együtt. A modell futtatása során így összesen 72 helyszínt vettünk figyelembe (5. ábra).

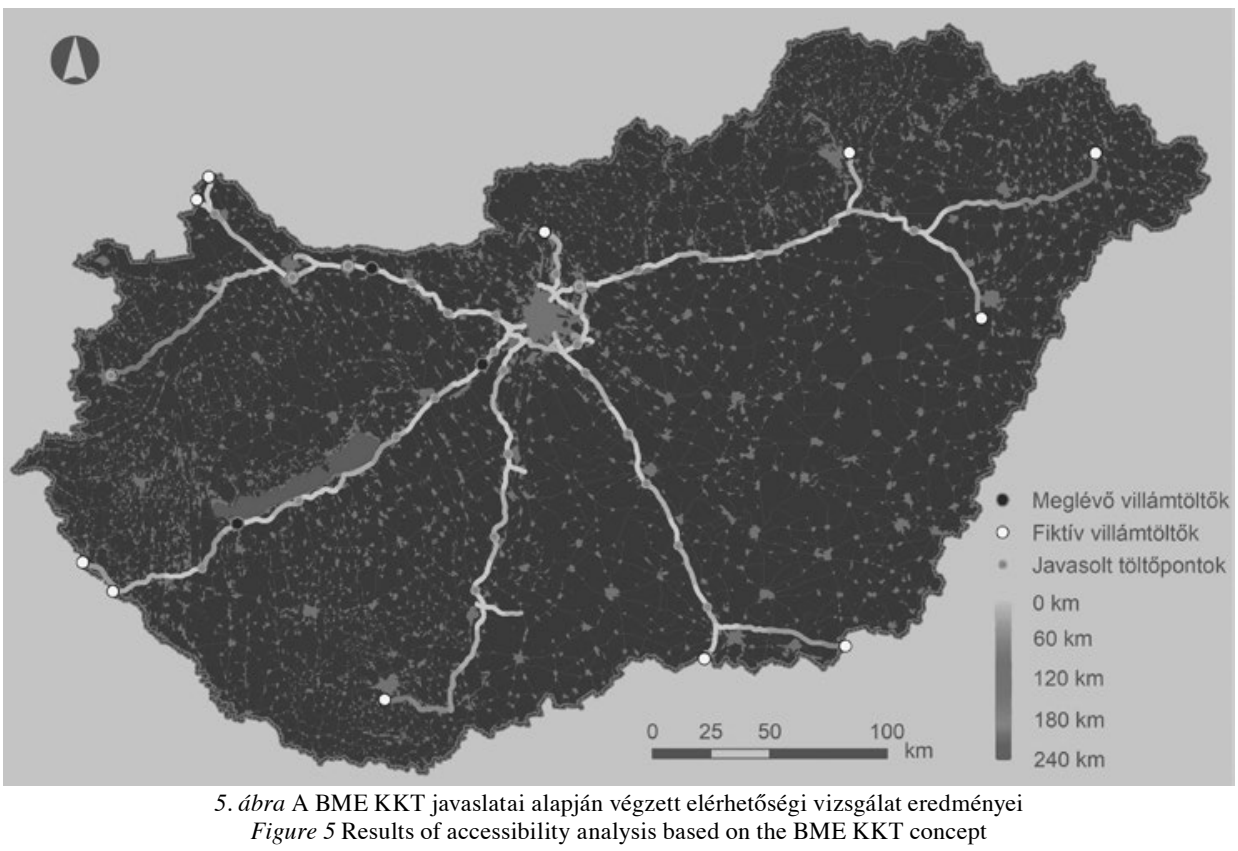

Bár a BME KKT vizsgálata kifejezetten Magyarország teljes lefedettségére irányult, a tanulmányukban javasolt töltőállomás-helyszínek modellezésünk alapján megfeleló sürüségben vannak ahhoz is, hogy biztosítsák az ország gyorsforgalmi átjárhatóságát. 
A javasolt töltőpontoktól számított 20 km-es távolságon belülre eső útszakaszok 48,9\%-ot tesznek ki a modellezés során figyelembe vett gyorsforgalmi utak teljes hosszához képest, míg a 20-40 km közötti szakaszok 32,7\%-ot, a 40-60 km közötti szakaszok pedig 10,5\%-ot.

\section{Az ELTE KTF eredményei}

A saját javaslatok alapján kijelölt töltőpontok száma 99 helyszínt foglal magába, amelyek közül 8 teljesen megegyezik a jelenleg már üzemben lévő töltőkkel, ugyanakkor kiegészül a fiktív töltőpontokkal, ami összesen 106 helyszínt eredményez. Az első körben javasolt töltőállomásokkal lefuttatott elérhetőségi vizsgálat esetében a potenciális töltőpont-helyszínektől számított $20 \mathrm{~km}$-en belülre eső szakaszok a teljes vizsgált úthossznak 59,1\%-át adják, míg a 20 és $40 \mathrm{~km}$ között ez az érték 29,9\%, a 40 és $60 \mathrm{~km}$ közötti pedig 7,4\%. Ezáltal a gyorsforgalmi utak teljes hosszának 96,5\%-a az első három kilométer-kategóriába tartozik. Azonban még ennek ellenére is megjelennek olyan töltóhiányos szakaszok, ahol a két töltési lehetőség között lévő útszakasz hossza meghaladja az 50 km-t (6. ábra). Ez a távolság egy alacsony akkumulátor-töltöttségű személyautó esetében már kockázatos lehet, ezért az ilyen szakaszokon is szükséges a megfelelö számú villámtöltók kialakítása.

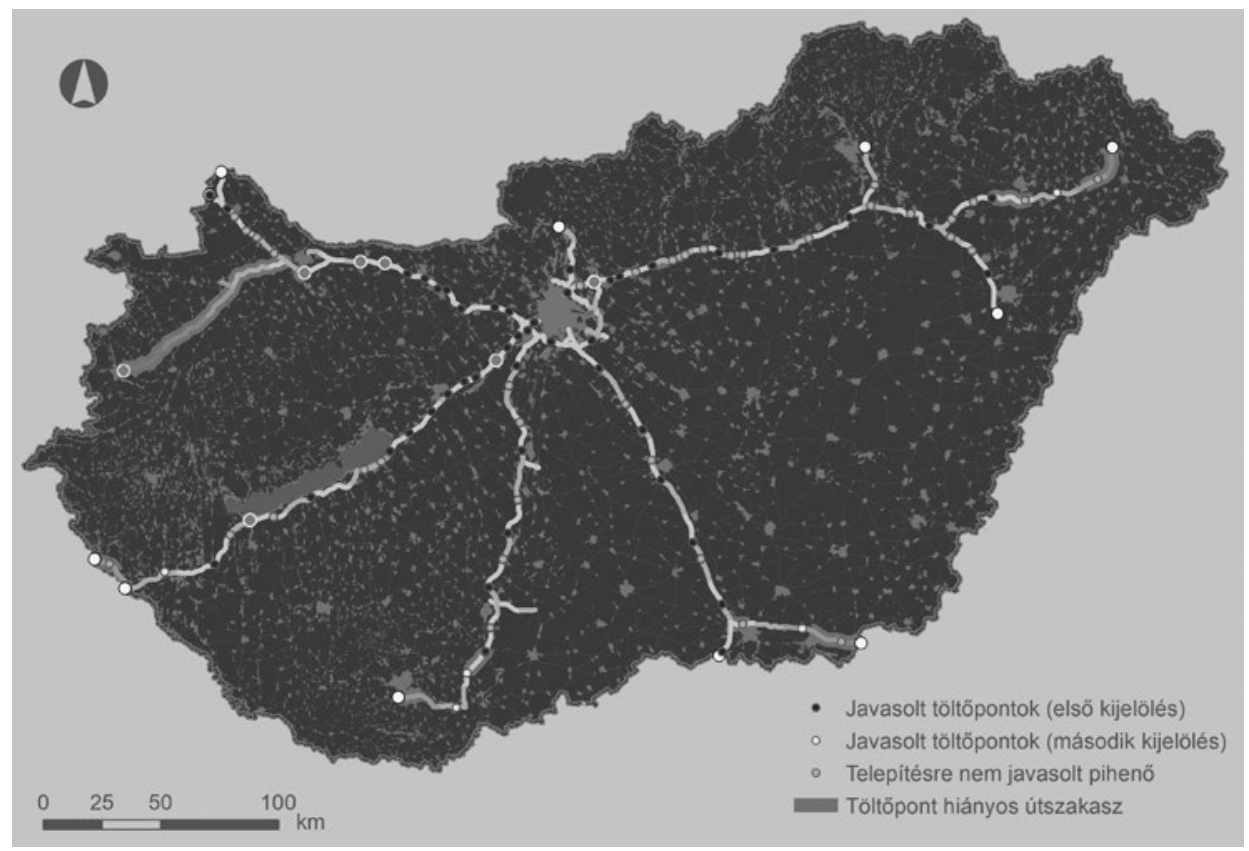

6. ábra Az ELTE KTF-módszertan alapján végzett 1. körös elérhetőségi vizsgálat eredményei Figure 6 Results of accessibility analysis based on the 1st phase of the ELTE KTF methodology

A második körös kijelölés esetében, a szükséges szakaszokon, további 7 helyszín hozzáadását követően, 113 pont vett részt a vizsgálatban. A módszer az alkalmazott hiátusokat kitöltő eljárás alapján megfelelőnek bizonyult. Az újbóli modellfuttatás eredményeinek alapján javasolt töltôpontoktól számított $20 \mathrm{~km}$-en belülre eső kumulált távolság a teljes úthossz 63,4\%-a, míg a 20 és 40 km közötti kategóriában 31,3\%, a 40 és 60 km közötti pedig 2,7\%. Ezáltal az első, második és harmadik távolság-kategóriába eső területek a teljes gyorsforgalmi úthossz 97,4\%-át jelentik, ami az első körös kijelöléshez képest 0,9\%-os javulást jelent. 
A leghosszabb útszakasz, ahol nem áll rendelkezésre pihenőhely, az M86-os autóuton található. Ezen az új építésú szakaszon ennek következtében nincs lehetôség töltőhelyszín kijelölésére sem az első, sem a második kijelölés során. Ebben az esetben a két meglévő töltőállomás (a győrújbaráti és a szombathelyi villámtöltő) között jelentős, $100 \mathrm{~km}$ a távolság, ami egy átlagos elektromos személyautó számára optimális üzemi körülmények között teljesíthető, azonban kedvezőtlen körülmények között fennállhat az akkumulátor lemerülésének veszélye (7. ábra). Tehát amíg az M86-os autóton nem létesül pihenôhely és nem alakítható ki elektromos töltőállomás, addig a legvalószínúbb megoldás az útvonalról való letérés és a közelben történő feltöltés (ám jelenleg csak 1 villámtöltő érhető el az út 5 km-es körzetében, Csornán).

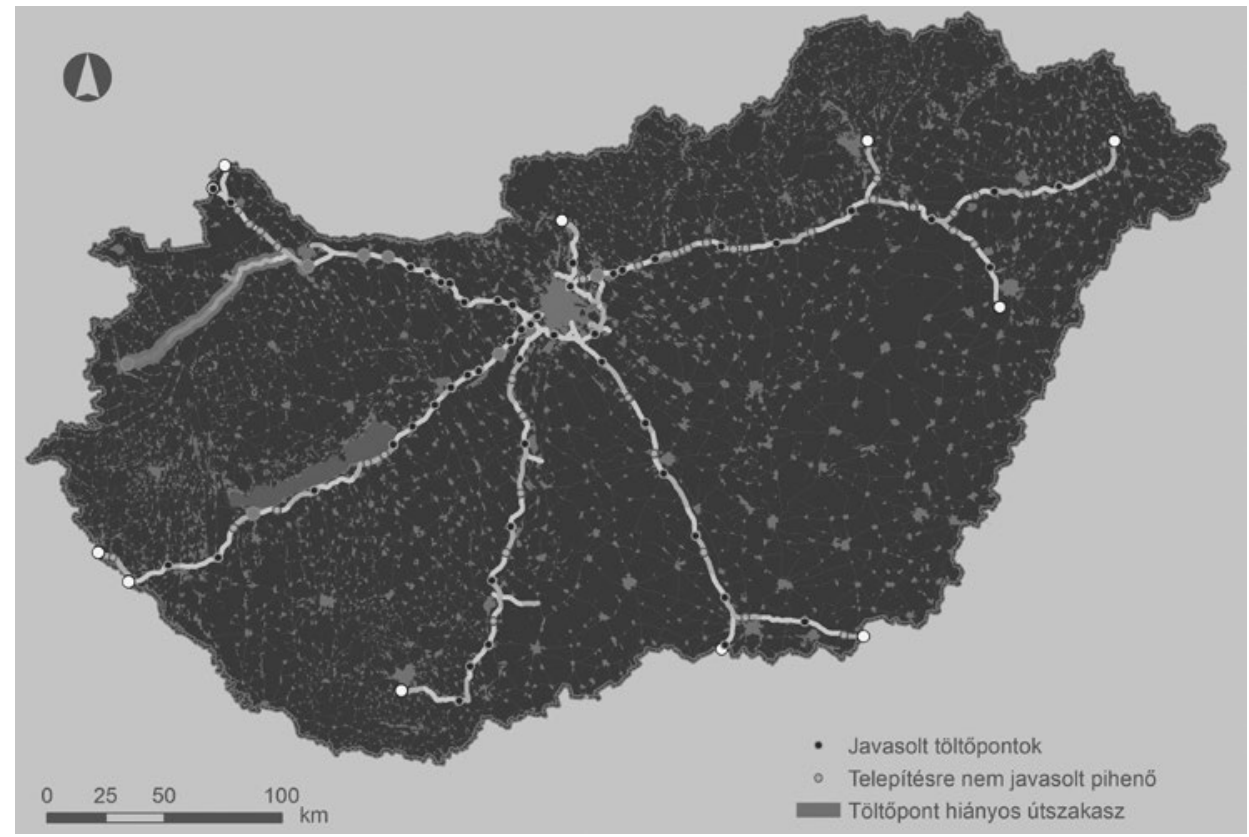

7. ábra Az ELTE KTF-módszertan alapján végzett 2. körös (végleges) elérhetôségi vizsgálat eredményei Figure 7 Results of accessibility analysis based on the 2nd (final) phase of the ELTE KTF methodology

Az eredmények alapján a villámtöltőknek az ELTE KTF módszertana által javasolt telepítése lehetôvé tenné az ország átjárhatóságát a gyorsforgalmi utak mentén, akár a legalacsonyabb hatótávval rendelkező elektromos hajtású jármúvel is (kivéve az imént bemutatott pihenőhely- és töltőállomás-hiányos területen). Ami elhelyezkedésüket illeti, Budapest irányába haladva a forgalom volumenének növekedésével a javasolt töltóállomások egyre sûrűbben fordulnak elő, ami jól látható az M1-es és M7-es autópálya mentén. Ezeken a területeken több lehetôség állhat rendelkezésre az autó feltöltésére, ezáltal a sűrű töltóállomásokkal rendelkező útszakaszokon eloszlanak a töltendő jármúvek.

\section{A fejlesztési elképzelések összehasonlitása}

Az E.ON-MOL, a BME KKT és az ELTE KTF módszertana alapján meghatározott töltőállomások figyelembevételével készített vizsgálatok egymással összehasonlíthatók, hiszen - bár különböző megközelítéssel, de - mindhárom esetben az ország átjárhatóságát 
biztosító elektromos töltőhálózat potenciális helyszíneinek kijelölése volt a cél. A három elemzés között a töltőpontoktól számított 20 kilométerenként meghatározott kategóriák alapján figyelhetők meg a legnagyobb különbségek, amelynek százalékos megoszlását a 8. ábra oszlopdiagramjai szemléltetik. Az egyes távolsági kategóriákra jutó részarányok forgatókönyvek közötti változásai jól illusztrálják, hogy a nagyobb elemszámú, racionális helyszínkiválasztás kedvezően hat a töltőpontok szolgáltatási „,területeire”. Az E.ON-MOL által meghatározott helyszínek esetében a potenciális töltők között 100 és 120 km távolság is előfordulhat, bár ezek a gyorsforgalmi utak teljes úthosszának csupán 1\%-át adják, ami mindössze 27,5 km. Ezzel szemben a BME KKT- és az ELTE KTF-kutatás által javasolt töltőpontok esetében nincs $100 \mathrm{~km}$-nél hosszabb lefedetlen útszakasz. Emellett, míg a 40 és 100 km közé eső úthossz a BME KKT elemzésében összesen 521,4 km, addig a saját (ELTE KTF) módszertan szerint mindössze 153,2 km. Ezek az értékek lényegesen magasabbak az E.ON-MOL elképzeléseiben, hiszen a 40 és $100 \mathrm{~km}$ közötti távolságban lévő szakaszok hossza $937,1 \mathrm{~km}(33,2 \%)$.

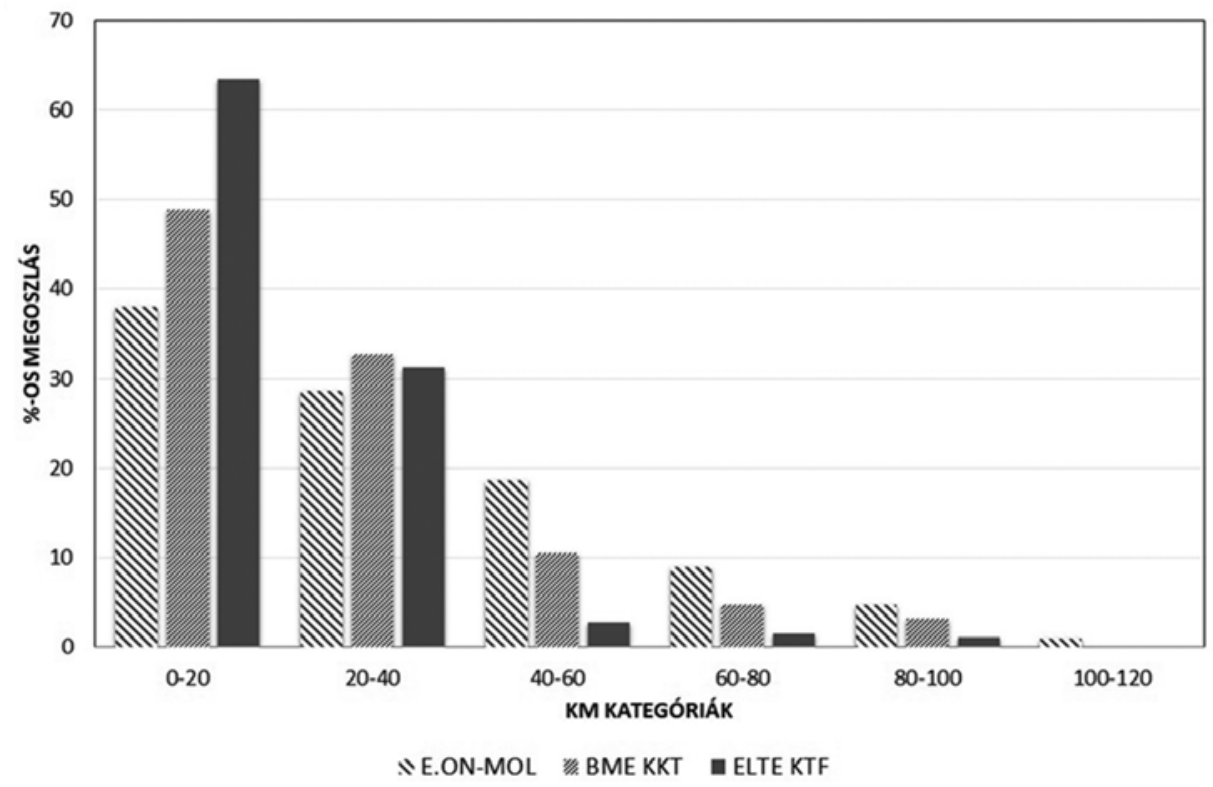

8. ábra Az egyes útszakaszok távolság kategóriákba való besorolásának százalékos megoszlása az E.ON-MOL, a BME KKT- és az ELTE KTF-módszertan alapján

Figure 8 Percentage breakdown of distance categories of road segments based on E.ON-MOL, BME KKT and ELTE KTF concepts

A töltőpontoktól számított $20 \mathrm{~km}$-en belüli kategória esetén is látható a különbség, hiszen összehasonlítva az ELTE KTF eredményeivel, a BME KKT-tanulmány össz-távolsága között $430 \mathrm{~km}$ a különbség, míg az E.ON-MOL esetében ez az érték $686 \mathrm{~km}$. Ennek a legfőbb oka nyilvánvalóan az, hogy mind a BME KKT tanulmányában, mind pedig az E.ON-MOL célkitűzésében javasolt töltőállomás-helyszínek számánál több helyszínt javasoltunk a három forgatókönyv felvetéseit összehasonlító modellezés során (1. táblázat). A lehető legkedvezőbb helyzetet, vagyis hazánk autópályáinak optimális átjárhatóságát természetesen azzal lehetne elérni, ha minden alkalmas pihenőben elektromosautó-töltőpontokat alakítanának ki. 
Az E.ON-MOL-, a BME KKT- és az ELTE KTF-módszertan eredményeinek összehasonlítása

Results comparison of E.ON-MOL, BME KKT and ELTE KTF concepts

\begin{tabular}{lccccccc}
\hline \multirow{2}{*}{ Módszertan } & Töltőpontok & \multicolumn{6}{c}{ Kumulált útszakaszhossz } \\
& Száma & $\mathbf{0 - 2 0}$ & $\mathbf{2 0 - 4 0}$ & $\mathbf{4 0 - 6 0}$ & $\mathbf{6 0 - 8 0}$ & $\mathbf{8 0 - 1 0 0}$ & $\mathbf{1 0 0 - 1 2 0}$ \\
\hline E.ON-MOL & 53 & 1124 & 846 & 550 & 264 & 141 & 28 \\
BME KKT & 72 & 1380 & 923 & 298 & 134 & 90 & 0 \\
ELTE KTF & 106 & 1810 & 894 & 79 & 44 & 30 & 0 \\
\hline
\end{tabular}

\section{Összefoglalás}

Fontos egyértelmúvé tenni, hogy a vizsgált koncepciók más-más szempontok alapján igyekeztek meghatározni a töltőállomások helyszíneit. Míg az E.ON-MOL javaslatai az üzleti érdekek mentén jelölték ki a potenciális helyszíneket, addig a BME KKT koncepciójának célja a minél átfogóbb területi lefedettség volt. Az ELTE KTF kidolgozta módszertan ezekkel szemben átjárhatósági optimalizációra törekedett a helyszínek kiválasztása során. Következésképp a három koncepció egymással csak bizonyos mértékig vethető össze, de jelen kutatásnak nem is volt célja bármiféle rangsorolás ezek között.

A modellezés során kirajzolódott, hogy a gyorsforgalmi utak mentén jelenleg rendelkezésre álló elektromosautó-töltőhálózat a hosszú távú elektromos autózás követelményeinek kielégítésére csak korlátozottan alkalmas. A vizsgálat arra enged következtetni, hogy a már meglévő a töltőállomások térbeli elhelyezésekor nem az országos átjárhatóság megteremtése volt a stratégiai cél, hiszen jelenleg a töltóállomások mindössze 5\%-a helyezkedik el az autópályák közvetlen közelében és ennek csupán a fele villámtöltő, amelyek hosszú távú közlekedés kielégítéséért volnának felelősek.

Jelen kutatás arra igyekezett rávilágítani, hogy célszerú volna olyan állami programot kezdeményezni, amelyben a térinformatika eszközrendszerét felhasználva a töltôhálózat helyszíneit optimálisan lehetne megtervezni és kivitelezni. Előbb-utóbb bizonyosan minden alkalmas helyszínt, így a pihenőhelyeket és üzemanyagtöltő-állomásokat is fel kell majd használni elektromos autók töltését szolgáló állomások kialakítására, de addig is fontos volna a telepítés térbeliségének és ütemezésének optimalizálása, vagyis annak figyelembevétele, hogy hol vannak jelenleg ebből a szempontból a legkritikusabb útszakaszok (pl. M86 autópálya). Ezeket a tapasztalatokat a jövőbeli gyorsforgalmi utak fejlesztési projektjeiben már a tervezéskor indokolt volna figyelembe venni.

Ugyanakkor fontos hangsúlyozni, hogy az elektromos autók és a töltőhálózat gyors fejlődése is gyorsan amortizálja a téma kutatása során felszínre kerülő összefüggéseket és eredményeket. Az akkumulátor-kapacitások növekedése elméletileg a töltőpont-hálózat térbeli ritkulásához is vezethetne, ám az elektromos jármúvek számának gyors növekedése ezzel ellentétes folyamatot generál, miközben a szinte naponta telepített új töltőpontok gyorsan rajzolják át a korábban felvázolt képet (DiXON, J.-BELL, K. 2020). A változás ütemét jól érzékelteti, hogy jelen kutatómunka megkezdése és lezárása közötti időszakban (2019. szeptember 12-2020. július 26.) 192 új nyilvános elektromos töltôt, köztük 38 villámtöltôt létesítettek hazánkban, ami rendre 28,7\%-os, illetve 28,3\%-os bóvülést jelent. 
Ugyanakkor villámtöltőkből ez idő alatt mindössze hármat helyeztek el közvetlenül valamelyik autópályánkon.

\author{
SOHA TAMÁS \\ ELTE TTK Környezet- és Tájföldrajzi Tanszék, Budapest \\ tamas.soha@gmail.com
}

NÉMETH IZABELLA

KTI Közlekedésfejlesztési Kutatóközpont Hálózattervezési Osztály, Budapest nemeth.izabella@kti.hu

\author{
MunKÁCsy BÉLA \\ ELTE TTK Környezet- és Tájföldrajzi Tanszék, Budapest \\ munkacsy.bela@ttk.elte.hu
}

\title{
IRODALOM
}

Alegre, S.-MígueZ, J. V.-CARPIO, J. 2017: Modelling of electric and parallel-hybrid electric vehicle using Matlab/Simulink environment and planning of charging stations through a geographic information system and genetic algorithms. - Renewable and Sustainable Energy Reviews 74. pp. 1020 -1027.

CAPAR, I.-KuBY, M. 2012: An efficient formulation of the flow refueling location model for alternative-fuel stations. - IIE Transactions 44. 8. pp. 622-636.

Chung, S. H.-Kwon, C. 2015: Multi-period planning for electric car charging station locations: A case of Korean Expressways. - European Journal of Operational Research 242. 2. 16. pp. 677-687.

Csiszár Cs.-Csonka B.-Földes D.-WirTh E.-Lovas T. 2018: Az országos átjárhatóságot biztosító elektromos villámtöltő-állomások helyszínét kijelölő módszer. - Közlekedéstudományi Szemle 68. 1. pp. 14-25. doi:10.24228/KTSZ.2018.1.2

DiXON, J.-BELL, K. 2020: Electric vehicles: battery capacity, charger power, access to charging and the impacts on distribution networks. - eTransportation 5. pp. 1-18. doi:10.1016/j.etran.2020.100059

DMCEU 2019: Denmark's Integrated National Energy and Climate Plan. - Danish Ministry of Climate, Energy and Utilities, Copenhagen. 184 p.

https://ens.dk/en/our-responsibilities/energy-climate-politics/eu-energy-union-denmarks-national-energyand-climate

DONG, G.-MA, J.-WEI, R.-HAYCOX, J. 2019: Electric vehicle charging point placement optimisation by exploiting spatial statistics and maximal coverage location models. - Transportation Research Part D 67. pp. 77-78.

Európa Tanács 2019: Az európai zöld megállapodás (EU Green Deal). https://eur-lex.europa.eu/legal-content/EN/TXT/?qid=1588580774040\&uri=CELEX:52019DC0640

Frade, I.-Ribeiro, A.-Gonçalves, G.-Antunes, A. P. 2011: Optimal Location of Charging Stations for Electric Vehicles in a Neighborhood in Lisbon, Portugal. - Transportation Research Record: Journal of the Transportation Research Board 2252. 1. pp. 91-98. doi:10.3141/2252-12

GERSE J. 2020: Felvillanyozva: az elektromos autók töltőhálózatának terjedése Magyarországon. - Területi Statisztika 60. 4. pp. 461-476. DOI: 10.15196/TS600403

Hanabusa, H.-HoRiguhCi, R. 2011: A Study of the Analytical Method for the Location Planning of Charging Stations for Electric Vehicles. - Lecture Notes in Computer Science pp. 596-605. doi:10.1007/978-3-64223854-3_63

He, Y.-Kockelman, K. M.-Perrine, K. A. 2019: Optimal locations of U.S. fast charging stations for long-distance trip completion by battery electric vehicles. - Journal of Cleaner Production 214. pp. $452-461$. doi:10.1016/j.jclepro.2018.12.188

Hodgson, M. J. 1990: A Flow-Capturing Location-Allocation Model. Geographical Analysis 22.3. pp. $270-279$.

Kuby, M.-Lim, S. 2004: The flow-refueling location problem for alternative-fuel vehicles. - Socio-Economic Planning Sciences 39. pp. 125-145.

LIU, J. 2012: Electric vehicle charging infrastructure assignment and power grid impacts assessment in Beijing. - Energy Policy 51. pp. 544-557. doi:10.1016/j.enpol.2012.08.074

Pevec, D.-Babic, J.-Carvalho, A.-Ghiassi-Farrokhfal, Y.-Ketter, W.-Podobnik, V. 2020: A SurveyBased Assessment of How Existing and Potential Electric Vehicle Owners Perceive Range Anxiety. - Journal of Cleaner Production 276. 10. pp. 1-23. doi:10.1016/j.jclepro.2020.122779 
PWC Magyarország 2013: Kitekintés az elektromos autók jövőjére. - 13 p. https://www.pwc.com/hu/hu/kiadvanyok/assets/pdf/e-car-survey-hu.pdf

SHAHRAKI, N.-CAI, H.-TURKAY, M.-XU, M. 2015: Optimal locations of electric public charging stations using real world vehicle travel patterns. - Transportation Research Part D: Transport and Environment 41. pp. $165-176$.

\section{Felhasznált adatbázisok:}

E.ON - Villámtöltố telepítések adatbázisa

https://www.eon.hu/hu/kozigazgatasi/termekek/villamtolto-telepites.html

MK Nonprofit Zrt. 2018: Az országos közutak 2018. évre vonatkozó keresztmetszeti forgalma

https://internet.kozut.hu/kozerdeku-adatok/orszagos-kozuti-adatbank/forgalomszamlalas

MOBILITI (NKM TÖLTŐPONT) mobiltelefonos applikáció adatbázisa.

https://toltopont.eu/ 


\title{
AZ LMBTQ TURIZMUS KÍNÁLATI OLDALÁNAK VIZSGÁLATA A MAGYARORSZÁGI EGYETEMISTÁK KÖRÉBEN
}

\author{
SZABÓ BALÁZS ATTILA \\ RESEARCH ON THE SUPPLY SIDE OF LGBTQ TOURISM \\ AMONG HUNGARIAN UNIVERSITY STUDENTS
}

\begin{abstract}
The following research aims to focus on the local touristic offerings for LGBTQ tourists in Hungary. The degree of social acceptance, the analysis of tourism infrastructure, and suprastructure-including the issue of security-will be the main focal points. Furthermore, different results of previous studies on the issue of social acceptance will support the present investigation. The conducted survey about LGBTQ-tourism was submitted predominantly to a straight audience. The questions intended to be answered are: What is the connection between marketing strategies of LGBTQ tourism in Hungary and the general attitude of citizens with university qualification towards homosexuals? Why did Budapest not develop into a typical LGBTQ destination like other European capital cities such as Madrid or Berlin? In this sense a touristic perspective is being added to existing investigations about the general social acceptance of LGBTQ people. Overall, the reader gains insight into the present situation in 2020 concerning LGBTQ-tourism and its supply side elements. A list of influencing factors such as politics, state involvement, marketing strategies and social attitudes are analyzed. A possible forecast is represented concerning future developments of LGBTQ-tourism in Hungary.
\end{abstract}

Keywords: gay tourism, gay studies, LGBT, pinktourism, gay geography, LGBT tourism

\section{Bevezetés}

Az LMBTQ turizmus fogalma: leszbikus, meleg, biszexuális transznemú és queer emberek csoportjára specializálódott szolgáltatások és marketing összesége egy adott LMBTQ-barát miliővel rendelkezô desztinációban. A történelem során az LMBTQ emberek mindig is jelen voltak a társadalomban. Ennek láthatósága mindig az adott kor társadalmi, politikai nyitottságától, berendezkedésétől függött. Ma sincs ez másképp, ezért ezekre a tényezőkre, mint az LMBTQ turizmus alapfeltételeiként kell tekintenünk. A nem heteroszexuális emberek napjainkra a globalizációval összefüggésben és a társadalmipolitikai változások következtében ugyan láthatóbbá váltak, de továbbra is rejtôzködő populációként vannak jelen a társadalomban. A térre gyakorolt kölcsönhatásuk azokon a helyszíneken mutatkozik meg, ahol szabadon tudnak találkozni közös szexuális és kulturális értékek alapján (CASTELLS, M. 1983). Kutathatóság szempontjából, az információs világunknak és az online tereknek köszönhetően napjainkra ezek az emberek egyre inkább elérhetôvé váltak.

Maga a meleg turizmus, amit az angol „gaytourism” kifejezés tükörfordításaként használok, egy keresletorientált turizmusformaként írható le. Bár tanulmányomban gyakran a teljes LMBTQ csoportot említem, kutatási tapasztalataimra és a kínálati oldal specifikusságára hivatkozva azt érzékeltem, hogy turizmus ezen szegmensében döntő többségében meleg- és biszexuális férfiak vesznek részt. Az eredményeim ebből fakadóan sokkal inkább a meleg férfiak csoportjára vonatkoznak. A világ turizmusában a meleg turizmus aránya 2016-os adatok alapján legalább 3\%, ami fóként a nyitottabb nyugati civilizáció területére összpontosul (UNWTO 2017). Fontos megemlíteni, hogy a kutatások szerint 
a lakosság 5-7\%-a tartozik az LMBTQ csoportba, ennél azonban lényegesen kisebb azoknak az aránya, akik eltérő szexualitásukat nyíltan felvállalva élnek.

Mint azt korábban említettem, az LMBTQ turizmusban többnyire csak a homoszexuális férfiak vesznek részt. Fenti megállapításom a következőkkel magyarázható: egyrészt az LMBTQ csoporton belül magasabb a láthatósága a meleg férfiaknak, másrészt a két nem eltérő térhasználati szokásai, melyben kimutatható, hogy a férfiak természetükből fakadóan sokkal inkább kötődnek a területiséghez, mint a nők (CASTELLS, M. 1969). Továbbá azt láthatjuk, hogy a meleg, illetve biszexuális férfiak körében magasabb a képzettek aránya (CASTELLS, M. 1969), így ebből arra következtethetünk, hogy magasabb átlagkeresettel is rendelkeznek. Ezt a következtetést erősítheti az is, hogy ha párban vannak, akkor a közös háztartás két férfi keresetből áll, a gyermekvállalás pedig ritka vagy korlátozott.

A turizmus szektor napjainkra egyre jobban specializálódik különböző keresleti csoportokra. Ilyen viszonylag szúk réteget képvisel az LMBTQ avagy meleg turizmus is, amely napjainkban a nemzetközi turizmus egyik feltörekvő trendjei közt van jelen. A magyar terminológiában és geográfiában ez a fogalom még nem igazán honosodott meg. Hazánkban a téma kutatása igen nagy újdonsággal bír mind a turizmus, mind a geográfia területén. A desztináció marketingnek, együttmúködéseknek egy térség turizmusában nagyon fontos szerepe van (BALÁZS F. 2018). Ezért fontos megemlítenünk azt a tényt is, hogy ez a szegmens jelenleg nem tartozik a kiemelt turisztikai fejlesztési célok közé. Más támogatott turisztikai irányvonalaktól - családosok, idôsek - kutatói szempontból abban tér el, hogy ez a szegmens speciális, kevésbé megfogható és szexuális irányultságon alapul, valamint társadalmi megítélése megosztó. Emiatt sokkal komplexebb és óvatosabb megközelítés kívánatos a téma kutatása során.

A kutatás fő kérdése az, hogy hogyan függ össze a magyarországi LMBTQ turizmus kínálata és a társadalom egy részének melegekhez való viszonya? Számos nagyvárosban virágzik az LMBTQ turizmus, vajon mi lehet az oka, hogy Budapesten ez nem jelenik meg markánsan? Továbbá a magyar magasan kvalifikált városi lakosság hogyan viszonyulna egy LMBTQ irányú turisztikai fejlesztési irányhoz? Ezekhez a kérdésekhez kapcsolódik online kérdőíves kutatásom. Jelen cikk áttekintést is ad arról, hogy Magyarország jelenleg hol helyezkedik el a világ és benne Európa meleg turisztikai piacán. Végül prognózisokat állítok fel a magyarországi meleg turizmus jövőbeli alakulásáról. Összességében a társadalmi elfogadottság, mint a meleg turizmus egyik alapfeltételét vizsgálom a szabadidő eltöltés szemszögéből.

\section{Szakirodalmi áttekintés}

Nemzetközi kontextusban számos piackutató cég, LMBTQ mozgalom és a különböző tudományok képviselôii is jelentős számmal végeztek kutatásokat. Ez a kutatási vonal az Amerikai Egyesült Államokból indult ki, Európában csak később jelent meg. Mára a meleg-leszbikus tanulmányok megsokasodtak az európai tudományos kutatásokban. Ennek oka, hogy Európa jelenlegi posztmodern társadalmában a szexuális sokféleség egyre elfogadhatóbbá válik és a modern társadalmi határok szétesnek (PLUMMER K. 1992). A szakirodalmi kutatás során észrevehető, hogy egyértelmú a téma angol-amerikai dominanciája, ahogy azt már Michal, P. (2019) is leírta. Az említett szerző a szexualitás és a geográfia kutatásának területi differenciáltságával foglalkozik (MicHAL, P. 2014; 2019). BROWN G. ÉS BROWNE K. (2016) a szexuális identitás térbeli különbségeivel és sajátosságait kutatták. Világszinten még kiemelkedő HuGHES H. 1997-es valamint 2006-os könyve, amelyek konkrétan teljes egészében az LMBTQ turizmusról szólnak, 
valamint megemlíthetők még MonTERRUBio C. (2009) amerikai és mexikói esettanulmányai. Melegturisztikai desztinációk körében végeztek kutatásokat PRITCHARD A. (1998) és munkatársai is. Európában, s azon belül főleg kelet felé haladva már csekélyebb menynyiségű munkát találunk. Előfordul, hogy egy-egy országban szigetszerúen vizsgálódnak a homoszexualitás és a turizmus kapcsolatának témakörében. Ezek középpontjában többnyire a moticáviókutatás állt, ahogyan azt TRIHAS N. (2018) görög kutató is tette. A szocializmus felbomlásáig a posztszocialista országokban nem folytattak tudományos kutatásokat ilyen témakörben (TímÁR J. 2007). A kelet-közép-európai térségben a téma egyik legfontosabb geográfus kutatója Michal PITONÁK volt, aki Prágában létrehozta a Queer Geography civil szervezetet, megteremtve ezzel a térségben a queer földrajz és szexualitások földrajzának kutatóközpontját.

A témában folyó hazai kutatások többnyire a szociológia és a pszichológia tudományok körében vannak jelen. Turizmus és marketing szempontból a téma már felkeltette néhány kutató, illetve szakdolgozó érdeklődését (BAKó F.-EISINGERnÉ B. B. 2017, TÖRŐCsIK M. 2002). TöRŐCsIK M. (2002) a meleg fogyasztók típusait, fogyasztói magatartásukat és a piacnagyságot vette górcső alá. KöLLEN T.-LÁZÁR Sz. (2012) rövid interjúkon keresztül vizsgálták külföldi meleg turisták motivációit Budapesten. A szexuális aktus, illetve az egyén önazonosság-keresésének motivációjáról ír KÁLMÁN L. (2019) nemrég megjelent cikkében, ahol többek között taglalja az LMBTQ közösség részcsoportjának jellemzőit és mobilitásának korlátait.

TóTH L. (1991, 2008) általánosságban elfogadó attitűdbéli elmozdulásról számolt be, ugyanakkor a társadalmi tudatban konzervatív fordulatot érzékelt. DuSA Á. (2011) kis létszámú egyetemista mintán végzett felmérést, melynek eredménye az volt, hogy az elfogadás mértéke nőtt, de érezhetô a megosztottság a témában kontextustól és egyéntől függően. DENCSŐ B.-SIK E. (2005) a négy visegrádi országban vizsgálta az LMBTQ emberek társadalmi elfogadottságát, amelyek közül Magyarország volt a legelutasítóbb. TAKÁcS J.-SzALMA I. 2014-ben végzett társadalmi elfogadottság vizsgálatának eredményei szintén nem túl kedvezőek a kisebbségi csoport szempontjából: 1-10 fokozatú skálán 3,2 értéket ért el a homoszexualitás társadalmi elfogadottságának mértéke. Az imént említett szerzőpáros több tanulmányban is foglalkozik a társadalmi elfogadottság kérdésével európai kontextusba helyezve a témát (TAKÁcs J.-SzALMA I. 2011; 2013). Az Európai Bizottság 2019-ben végzett egy diszkriminációs kutatást az Európai Unió országaiban. Magyarország esetében arra a kérdésre, hogy „Mennyire érezné kényelmetlenül magát, ha a gyermeke egy azonos nemúvel élne párkapcsolatban?” legalább 60\% válaszolt úgy, hogy kellemetlenül érezné magát (Eurobarométer 2019). Az említett kutatásokból kikövetkeztethető, hogy Magyarország az általam is vizsgált LMBTQ emberekkel szemben a társadalmi elfogadottság kérdésében az elutasító országok közé tartozik. Ugyanakkor jelen tanulmánynak nem célja a társadalmi elfogadottság kérdésének vizsgálata, hanem turisztikai szemszögből, az LMBTQ turistákhoz való viszonyulást hivatott mérni.

A témában több civil szervezet is komoly kutatásokat végez, mint például a Háttér Társaság, a Szivárvány Misszió Alapítvány, a Magyar LMBT Szövetség és a Humen Travel Turisztikai Egyesület.

\section{A meleg turizmus alapfeltételei és ezek teljesülése Magyarországon}

A meleg turisták fó motivációja az önazonosság keresése, önmaguk megélése LMBTQ környezetben. Az említett turisztikai magatartást az adott földrajzi tér társadalmi jellemzőinek tükrében kell vizsgálni (KULCSÁR L. 2020). A turizmuson belüli elhelyezés szem- 
pontjából a meleg turizmus a MiCHALKÓ G.-RÁTZ T. (2013) által is említett rejtett turizmus csoportjába sorolható. A melegek turizmusban betöltött szerepe a mai Magyarországon már ugyan kevésbé rejtett, de arányaiban csekély, ezért a lakosság szempontjából a mindennapokban nem érezhetô és elsősorban Budapest belvárosában jelenik meg.

A meleg turizmus alapfeltételei közé sorolhatjuk a biztonságot, a társadalmi elfogadottságot, továbbá a célcsoportra épülő turisztikai infra- és szuprastruktúrát. Ezt a hármas feltételrendszert „,biztonság, fogadókészség és -képesség” fogalmakkal már KÁLMÁN L. (2019) korábban leírta.

A turizmus szempontjából az egyik legfontosabb kérdés a biztonság. Ezen belül is meg kell különböztetnünk a jogi és a társadalmi biztonságot, mivel lehet, hogy egy adott országban ugyan jogilag teljes az egyenjogúság, ám a társadalom hozzáállása ezzel nem egyezik meg. A biztonság kérdése az LMBTQ szociálgeográfiai csoport esetében hatványozottan fontos, hiszen szexuális irányultságuk megosztó kérdés a társadalomban, így utazásuk során könnyen válhatnak atrocitások, gyűlölet bűncselekmények célpontjává.

Magyarország alaptörvénye több szempontból is kizárja az azonos nemúek kapcsolatát a család fogalmából, ellenben a bejegyzett élettársi kapcsolat intézménye létezik. Jogi értelemben mégis a kedvezőbb helyzetű országok közé tartozik, mert a szexuális orientáció alapján történő diszkrimináció büntetendő.

A média tudatformálásának mértékét ugyan hivatalosan mérni még nem tudják, de véleményem szerint jelentős hatással bír. Az elmúlt évben tapasztalatom szerint jelentősen megnőtt az LMBTQ témájú médiamegjelenések száma, amelyek többnyire negatív színbe helyezték a témát. A Coca-Cola Company 2019 nyarán nyíltan az LMBTQ emberek elfogadását célzó reklámkampányt folytatott Budapesten. Ez plakátokban, márkajelzésekben nyilvánult meg, melyet igen nagy sajtóvisszhang és heves politikai reakciók követtek többnyire negatív kontextusba helyezve a kampányt. Az ilyen esetek esetleges hátrányos következménye lehet, hogy az ország nemzetközi megítélése romlik. Ezt erősítette meg tapasztalataival a több nemzetközi turisztikai vásáron részt vett interjúalanyom, ERDEI ZsOLT is.

A hazai országos, de fóként baranyai médiában nagy visszhangja volt a tervezett Pécs Pride rendezvénynek is, megfigyelésem alapján heti 2-3 alkalommal jelent meg egy-egy cikk a téma kapcsán, szinte kizárólag negatív megközelítésből.

A Labrisz Leszbikus Egyesület által 2020 nyarán kiadott Meseország mindenkié címú mesekönyv talán minden eddiginél nagyobb reflektorfénybe helyezte az LMBTQ témát mind a médiában, mind a politikában és a közéletben. A kormány álláspontja a következő idézettel írható le: „el a kezekkel a gyerekeinktől”. Továbbá a közelmúlt eseményeihez tartozik az LMBTQ közösség szimbólumának számító szivárványzászló középületekre való kitűzése is, amely rávilágít arra, hogy egyes önkormányzatok támogatóként vannak jelen az említett közösséget illetően. Mindezeknek a társadalomi hozzáállásra is hatást gyakorolhatnak

A társadalmi elfogadottság mérésére számos szociológiai felmérést végeztek már nemzetközi és hazai téren. Mint az a Nemzetközi Szociális Felmérési Program által 1988 és 2008 között végzett kutatásokból kiderült, az LMBTQ emberekkel a nők, a magasabb iskolai végzettséggel rendelkezők, a fiatalok és városban élők a legelfogadóbbak (SMITH Toм W. 2011). A homofóbia mérésére az imént említett program adatait felhasználva Takács Judit és Szalma Ivett kutatópáros dolgozott ki modellt (TAKÁcs J.-SzALMA I. 2013). Kutatásaik szerint az azonos nemúek közötti partnerségi jogszabályok bevezetése a melegek és leszbikusok elleni attitűdök csökkenéséhez vezethet (TAKÁcs J.-SzALMA I. 2011). Ez utóbbi vizsgálat is azt támasztja alá, hogy egy ország politikai hozzáállásának nagy hatása lehet az LMBTQ csoport társadalmi elfogadottságára. 
A fenti kutatás más kontextusban vizsgálta a homoszexualitáshoz és az LMBTQ emberek csoportjához való hozzáállást, így eredményei csak korlátozottan összehasonlíthatók saját kutatási eredményeimmel. Nagyon fontos, hogy az érintettek köre utazásuk előtt tájékozódjon az adott célterület jogi, társadalmi hozzáállásáról. Ezt az LMBTQ turistáknak szükséges megtenniük, ebből fakadóan tájékozott célcsoportnak minősülnek. Felmerülhet a kérdés, hogy például egy meleg pár vagy egyén csak akkor számít meleg turistának, ha a fő motivációja az önazonosság keresése és önmaga megélése LMBTQ környezetben? Véleményem szerint igen, bár marketing szempontból egy rendkívül heterogén keresleti csoportról van szó, ahogy azt már TöRőCsIK M. (2002) is leírta.

\section{A kutatás módszertana}

\section{Kérdölves felmérés}

A kutatási módszer kiválasztásánál az volt az elsődleges szempont, hogy a lakosság véleményét fel tudjam tárni a témában, amelyre az online kérdőíves felmérés módszerét tartottam a legmegfelelőbbnek. A kérdőívet a Google ûrlapok szolgáltatás segítségével készítettem el, amelyet a Facebook közösségi oldalon terjesztettem, a magyar internethasználók döntő többsége ugyanis ezen a közösségi oldalon érhető el. A kérdőíves primer adatgyújjtés próbakérdezést követően 2020. január és február hónapokban történt. Mivel a megkérdezés online közösségi oldalakon történt, így nem mondható el, hogy a magyarországi lakosságára nézve a felmérés reprezentatív. A kérdőívben rákérdeztem a kitöltő szexuális irányultságára, így kívántam elkerülni, hogy a kutatás tárgyát képező LMBTQ csoport válaszaival torzítsa az eredményeket önmaga véleményezésével. A korösszetételt tekintve arányaiban a fiatal és az aktív korosztály válaszait kaptam meg, így a témáról csak közelítô információkat tudok megfogalmazni és nem beszélhetek össztársadalmi álláspontról.

A kérdésekre a válaszokat négy, illetve öt pontos Likert skálán tudták megadni a megkérdezettek. Ezek zárt, egyválaszos kérdések voltak, egy esetben egyéni vélemény kifejtésére is lehetőség volt. A kérdőívet 1000 fő töltötte ki és adattisztítás után 912 fő került a mintába, melyből $69 \%$ nő, $31 \%$ férfi volt. A minta demográfiai összetételét az 1. táblázat tartalmazza.

1. táblázat - Table 1

A kérdőíves minta nagysága és megoszlása

Sample size and distribution of the survey

\begin{tabular}{lrlrlr}
\hline & \multicolumn{4}{c}{ Mintamegoszlás $(\mathbf{9 1 2}$ fö) } \\
korcsoport & $\boldsymbol{\%}$ & lakóhely & $\boldsymbol{\%}$ & iskolai végzettség & \% \\
\hline 18 év alatti & 1 & Budapest & 28 & általános iskola & 2 \\
18-24 év & 26 & megyeszékhely & 49 & szakiskola & 1 \\
$25-39$ év & 62 & város & 13 & középiskola & 25 \\
40-59 év & 8 & község & 8 & felsőfokú szakképzés & 8 \\
60 év feletti & 3 & külföld & 2 & egyetem & 61 \\
& & & & doktori $(\mathrm{PhD})$ & 3 \\
\hline
\end{tabular}




\section{Félig strukturált mélyinterjúk készítése}

A félig strukturált mélyinterjúnak csak kiegészítő funkciója volt a kérdőíves felmérés mellett. Az interjú során az általam előre meghatározott vezérfonalhoz ragaszkodva tettem fel a kérdéseket. Az interjúalanyokat előzetes kutatás alapján választottam ki, amelynek során utánajártam, hogy mely személyek ismerhetik legjobban az LMBTQ turizmus kínálati oldalát. 2020 januárjában felkerestem néhány olyan szakembert, vállalkozót, akik járatosak a magyarországi meleg életben és naprakész információval szolgálhatnak a helyzetfelmérésemhez. Az egyik interjúalanyom ERDEI ZsOLT, a Humen Travel Turisztikai Egyesület elnöke volt, aki - mint az tevékenységéből kiderül - a magyarországi meleg turizmus egyik kulcsembere. Interjút készítettem továbbá KRISTÓFY MÁRIÁval, aki a Labrisz Leszbikus Egyesület egyik főszervezője. Kifejezetten hasznos információkhoz jutottam általa az amúgy is nehezebben elérhető leszbikus közösségről. Az interjúk során kapott információkat tényfeltáró és leíró jellegüknél fogva a hazai meleg turizmus kínálati oldalának ismertetésére használtam fel.

A deszináció fogadókészségének vizsgálata érdekében megkerestem a fóvárosi rendőrkapitányságot, ám a téma érzékenysége miatt az interjút nem engedélyezték. A fővárosi önkormányzat álláspontjára - válasz hiányában - a nyilvánosan megjelenő, egyértelmú álláspontot tükröző nyilatkozatokból következtettem.

\section{Online és nyomtatott Turisztikai kiadványok elemzése}

A hazai LMBTQ turizmus kínálati oldalának bemutatásához online és nyomtatott kiadványokat is elemeztem. A kínálati oldalt csekély számú szolgáltató jellemzi, így ez a módszer is célravezetô volt a témafeltárásában.

\section{Kutatási eredmények}

\section{A kérdölves felmérés eredményei}

A kérdőíves felmérés során arra kerestem a választ, hogy a lakosság hogyan viszonyulna a turizmus melegbarát fejlesztéséhez és hogyan látja annak esetleges hatásait? Kiemelt fontosságú a válaszok értékelése szempontjából, hogy a válaszadók $83 \%$-a több mint egy, 9\%-a legalább egy LMBTQ személyt ismer személyesen.

A kérdőív egyik fó kérdése az volt, hogy mennyire zavarná a helyi lakost, ha Magyarország, elsősorban Budapest melegbarát turisztikai desztinációvá válna a jövőben? A válaszadók közel kétharmada úgy nyilatkozott, hogy nem, illetve valószínúleg nem zavarná őket, s $19 \%$ válaszolta azt, hogy zavaró tényezőként élné meg ezt a változást (1.ábra). Amennyiben a kapott válaszokat a válaszadók lakóhelye alapján külön megvizsgáljuk, azt láthatjuk, hogy a negatív válaszok esetében a falusi válaszadók aránya 5\%-al magasabb a többi településtípushoz viszonyítva. Azok, akiket nem zavarna ez a jelző a legnagyobb arányban budapestiek voltak és a zavarás mértéke egyenes arányosságban van a településméret csökkenésével.

A következő kérdés arra irányult, hogy a válaszolók szerint milyen hatással lenne Magyarországra, ha melegbarát országként szerepelne a köztudatban? Ennek eredménye első ránézésre döntően pozitív, illetve semleges hozzáállást mutat, ám a válaszok nagyon megoszlottak. Ezt jól mutatja az is, hogy ennél a kérdésnél a válaszadók $11 \%$ élt az egyéni, kifejtôs válaszlehetôséggel. Az egyéni válaszok döntő többsége arról szólt, hogy ezt 


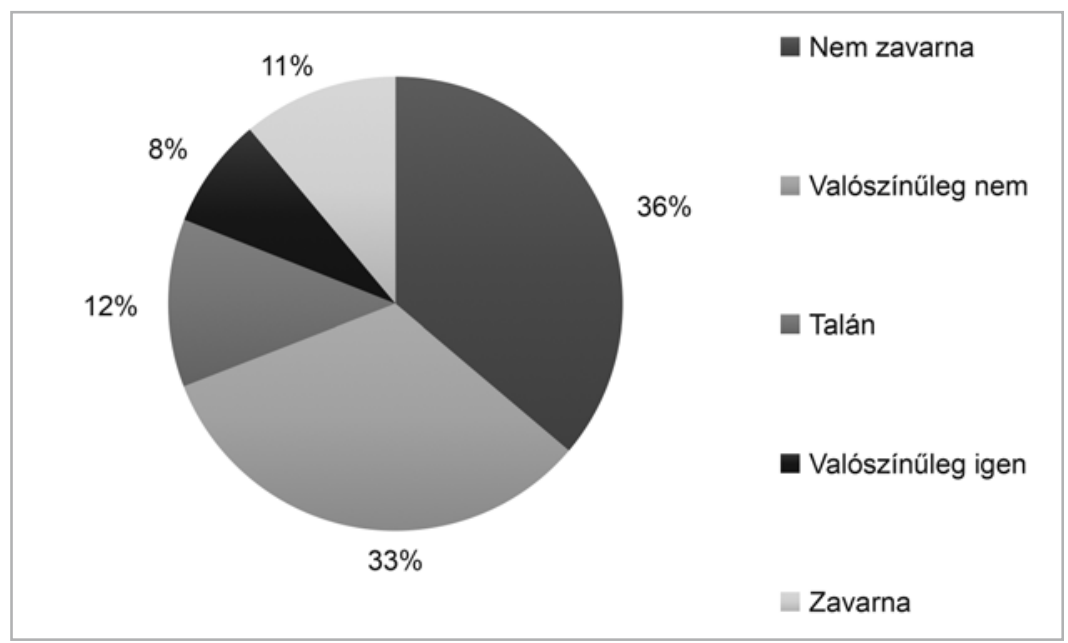

1. ábra Önt zavarná, ha Magyarország melegbarát célterület lenne a jövőben?

Figure 1 Would if be disturbing for you if Hungary became an LGBTQ-friendly destination in the future? Forrás/Source: saját felmérés/own survey

a kérdést több szempontból is lehet vizsgálni. Megítélésük szerint nemzetközi kontextusban abszolút pozitív megítélése lenne a változásnak, viszont hazai körben negatív következményei lehetnek. Többen kifejtették, hogy szerintük a magyar társadalom erre nincs felkészülve és nem olyan nyitott, a folyamat a kormányzati politikával is szembe menne, valamint a már korábban említett Coca-Cola LMBTQ-barát reklámkampányának negatív társadalmi visszhangjáról írtak. Összességében a válaszadók 67\%-a úgy nyilatkozott, hogy semmiképpen sem lenne negatív hatása az országra egy ilyen imázsnak. Ugyanakkor az egyértelmúen negatív vélemények kisebb arányban bár (21\%), de markánsan megjelentek (2.ábra).

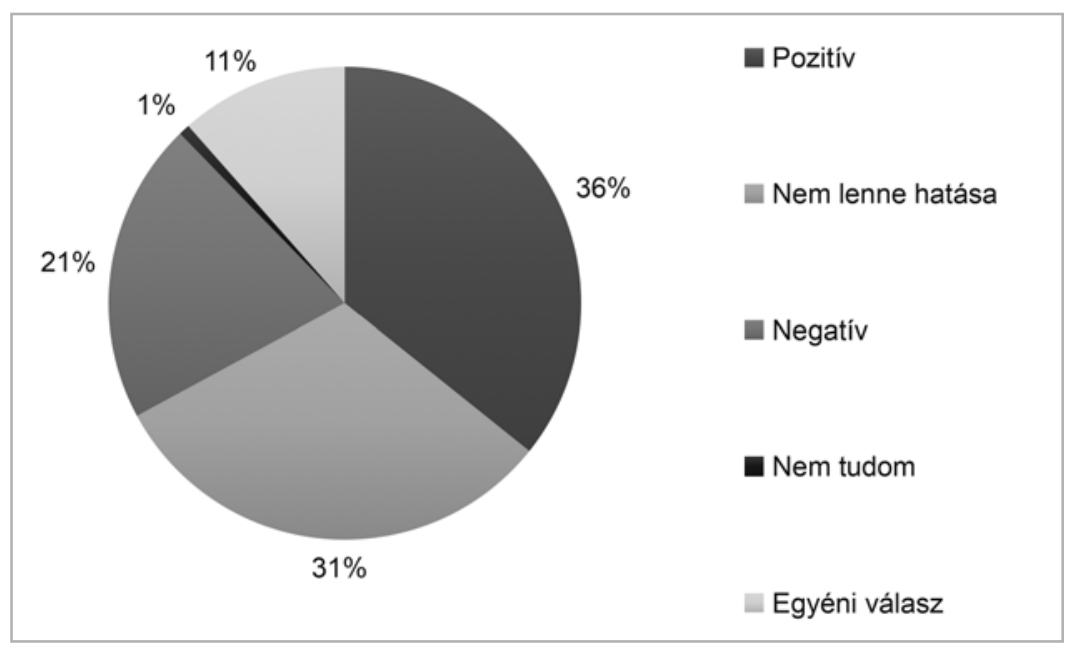

2. ábra Ön szerint milyen hatással lenne Magyarországra, ha melegbarátként szerepelne a köztudatban? Figure 2 What were the economic effects if Hungary became a gay-friendly destination in common knowledge? Forrás/Source: saját felmérés/own survey 
A válaszok települési mintázatát vizsgálva megállapíthatjuk, hogy a pozitív vélemények főként a fővárosból és a megyeszékhelyekről érkeztek. Akik szerint nem lenne semmiféle hatása az imázsváltásnak, fơként falusi válaszadók voltak. Negatív hatásokról főleg a megyeszékhelynél kisebb városokban élők nyilatkoztak. A településméret csökkenésével az egyéni válaszok száma is egyenes arányban csökkent. A válaszlehetőségek közül a tartózkodás alacsony minden településtípus esetében, így a kérdésról mindenkinek van valamilyen határozott véleménye. Fontos megjegyezni, hogy a felmérés alapvetően az aktív korúak és az egyetemista internethasználók véleményét tükrözi, tehát nem látjuk az idős korosztály véleményét, akik elöregedő társadalmunkban jelentős tömegeket képviselnek. A tanulmány ebből kifolyólag nagyobb fokú elfogadottságot mutat, szemben az általános szociológiai felmérések eredményeivel (KUYPER L. ET AL. 2013; TAKÁCS J.-SZALMA I. 2013). Ugyanakkor a szóban forgó budapesti belvárosi turisták által frekventált területeken vagy a budapesti éjszakai életben az említett korosztály kevésbé kerül kapcsolatba a turistákkal, mint a fiatalok vagy az aktívan dolgozók.

Az imázsnak a turizmusban nagyon fontos szerepe van. Az imázs „,egy személlyel, dologgal, térrel stb. kapcsolatban az emberek tudatában kialakult kép, a róla alkotott ítélet és előítélet összessége, amely nem szükségszerúen esik egybe a tényekkel, hanem többnyire szubjektív képzet, különböző asszociációk visszatükröződése, amelyet jelentősen formál számos külsố tényező (tévé, sajtó stb.) is” (KovÁcs 2001 JANKó 2002. p. 56). Az imázzsal összefüggő kérdésem arra vonatkozott, hogy egy LMBTQ-barát imázskép befolyásolná-e az érkező turisták számát Magyarországon, és ha igen, hogyan? A válaszok megoszlásában a vélemények korábbi kérdéseknél látott megosztottsága továbbra is jelen van. Ugyanakkor a 3. ábrán az is jól látható, hogy a vélemények negatív-pozitív irányok helyett a semleges-pozitív irányokba mutatnak. A válaszadók mindössze egynegyede látja úgy, hogy egy ilyen imázskép hatására növekedne a turisták száma. Szintén egynegyedét képezi a válaszoknak az a nézet, mely szerint egy esetleges LMBTQ imázskép egyáltalán nem befolyásolná a turistaérkezéseket. A bizonytalanok aránya 46\%, s mindössze 5\% gondolta úgy, hogy csökkentené a turistalétszámot (3.ábra). Valószínúleg az előző kérdésnél egyéni válaszokat adók markáns véleményeiből eredeztethető az, hogy a bejövő turisták számának csökkenésére kevesebben következtettek egy esetleges LMBTQ imázskép hatásaként.

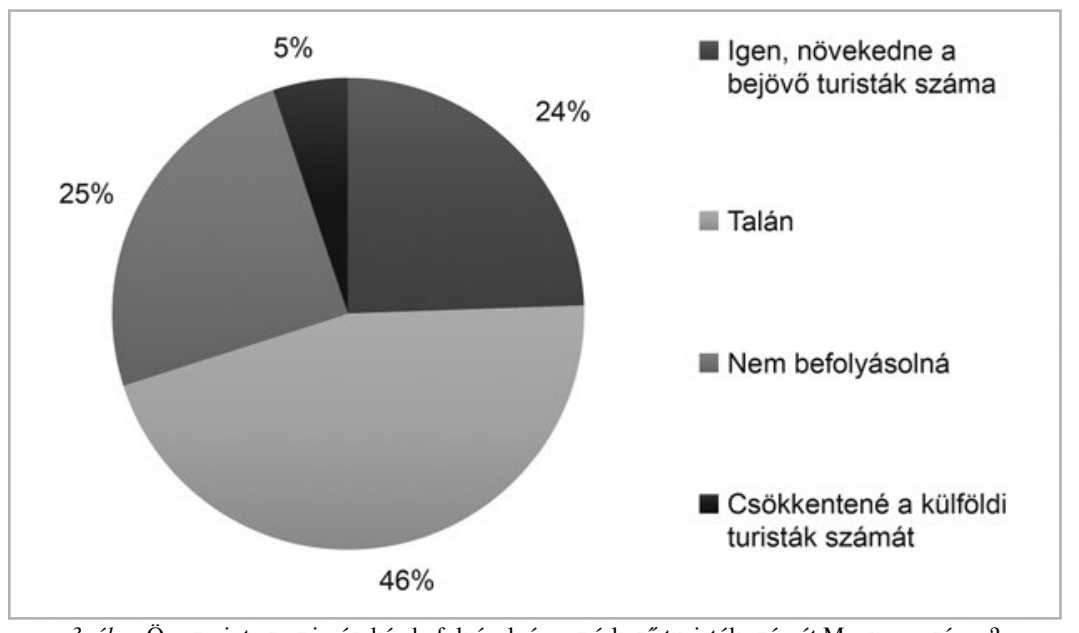

3. ábra Ön szerint ez az imázskép befolyásolná-e az érkező turisták számát Magyarországon?

Figure 3 According to your opinion would a more liberal mind set change the number of arriving tourists in Hungary? Forrás/Source: saját felmérés/own survey 
Települési kontextusba helyezve a kérdést, a megyeszékhelyeken és kisebb városokban élők összeségében a turistaszám növekedését várták, míg a falvakból és Budapestről válaszolók többségében azt állították, hogy nem lenne befolyásoló hatása. A turistaszám esetleges csökkenését várók aránya alacsony fokú, nem haladja meg az 5\%-ot.

\section{A meleg turisztikai kínálat elemzése}

Ezen fejezethez, valamint a turisztikai infra- és szuprastruktúra feltárásához az adatgyújtés online keresőmotorok, tematikus gyűjtőoldalak segítségével és az interjúalanyok megkérdezésével történt. Mivel nem nagy területről beszélünk a magyarországi turizmuson belül, így a témát az említett módszerek kombinálása teljes mértékben lefedte.

Magyarországon meleg éjszakai életrôl és ismerkedési lehetôségrôl a múltban és a jelenben is leginkább csak Budapest esetében beszélhetünk. A vidéki városokban mindössze csak Szegeden, Debrecenben és Miskolcon múködik meleg szórakozóhely. Ezek önmagukban komoly turisztikai vonzerő generálására nem képesek, mindössze a lokális LMBTQ közösség szórakozási igényeinek kielégítésére hivatottak elősegíteni. Budapest ezzel szemben, mint világváros és mint a nemzetközi turizmus egyik gócpontja, rendelkezik olyan vonzerővel és speciális kínálattal, amely vonzerôt jelenthet a meleg turisták számára. A szocializmus alatt a melegek többnyire gyógyfürdőkben, parkokban tudtak csak kapcsolatba lépni egymással (HANZLI P. ET AL. 2015). A leszbikus közösség szocializmus korabeli mindennapjaiba szintén életút interjúkon keresztül kaphatunk betekintést (BoRGOS A. 2011). A rendszerváltás után kezdődött meg a nyilvános meleg szórakozóhelyek kialakulása Budapesten, sorra nyitotta kapuit több bár és éjszakai klub. Az infokommunikációs korszakkal együtt nyílt meg a lehetôség arra, hogy a fővárosi LMBTQ kínálat a külföldi turisták előtt is ismertté váljon. Budapesten az első nyilvános úgynevezett pink pikniket 1993-ban, az első pride felvonulást 1997-ben rendezték meg. Hazánkban az LMBTQ csoport tértermelése cselekvőhálózati megközelítésben ettől kezdve vizsgálható, mivel az egyéntől kiindulva egészen a globális szintig kialakult szervezeti struktúra jött létre (BERKI M. 2017). A kezdetben néhány száz fős rendezvény 2019-re közel 20 ezer fősre duzzadt. A nagyvárosokban koncentrálódó kreatív gazdaságban dolgozók körében magasabb a homoszexuálisok száma, mely ilyen módon kapcsolódhat az új gazdaság és a homoszexuálisok térnyerésével Budapesten (BAJI P. 2015).

Az internet és az okostelefonok elterjedésével rohamosan átalakultak az ismerkedés színterei és ez nagyrészt a valós térből a kibertérbe helyeződött át. Ennek ellenére továbbra is van meleg éjszakai élet Budapesten, saját közösségi tereket múködtetnek, rendezvényeket szerveznek. Ugyanakkor az ide látogató meleg turisták nem tekintenek tipikus meleg desztinációként Budapestre és ez nem jelenik meg utazási motivációként (KöLLEN T.-LÁZÁr Sz. 2012).

Magyarországon a meleg turizmus intézményesített formában nem létezett egészen 2018-ig. Ekkor jött létre a Humen Travel Turisztikai Egyesület, melynek fő célja Budapest LMBTQ barát úti célként való népszerúsítése különböző marketing és reklámtevékenységgel. 2019 végén létrehozták a PinkBudapest elnevezésú projektet, amelyet számos cég támogat. Nagy hangsúlyt fektetnek az online kommunikációra (Instagram, Facebook, Youtube, LMBTQ médiák), valamint presstrip-eket is szerveznek külföldi újságíroknak. Továbbá mind a berlini, mind a FITUR-Madrid nemzetközi turisztikai vásárokon részt vesznek, ahol külön standja van az LMBTQ turizmusnak. A Humen Travel magazinja hat országban jelenik meg angol nyelven.

Vannak emellett szervezett, három órás, hat órás és éjszakai kimondottan kiscsoportos tematikus városnéző ,túrák” is (Pinkbudapest). A PinkBudapest projekt keretében online 
és nyomtatott kiadványok, imázsfilmek készülnek. Előbbi 11 európai országban jelenik meg évente kétszer és két fó szerepe van. Az egyik, hogy népszerúsítse Budapestet, mint elfogadó desztinációt, a másik, hogy az érkezés előtt információt adjon az LMBTQ turistának.

Tipikus LMBTQ szegmenshez köthető turisztikai terméktípusok Európában a fesztivál és buliturizmus, a városi turizmus és a tengerparti turizmus. Ebből fakadóan Magyarországon leginkább csak Budapest jöhet szóba, mint melegbarát turisztikai desztináció. Magyarország sajátosságából fakadóan a városi turizmus mellett a gyógy- és wellness turizmus és az egészségturizmus jelenthet kiváló kapcsolódási lehetőséget az LMBTQ keresleti csoportot illetôen. Az állami turizmusfejlesztési irányzatokban ez a célcsoport jelenleg nem jelenik meg, támogatásra nem lehet számítani, azonban beutaztatás és turisztikai termékértékesítés vállalkozói szinten, szabadon végezhető.

\section{A meleg turisztikai infra- és szuprastruktúra bemutatása}

A meleg turizmus turisztikai infrastruktúrájához sorolhatjuk a szórakozóhelyeket, bárokat, éjszakai klubokat, gyógyfürdőket és egyéb, a célközönségre specializálódott szolgáltatásokat. Ezek felkutatása online weboldalakról és nyomtatott turisztikai kiadványból történt meg.

Budapest meleg életét tekintve a korábbi titkos és kevésbé köztudott szórakozóhelyekből mára nagy létszámú partisorozatok, bulik nőtték ki magukat, amelyeknek a láthatósága is megnőtt. Korábban egy-két fix szórakozóhely, bár létezett, amelyekbe sokszor csak meghívásos alapon lehetett bejutni. Ma is csak néhány állandó zenés, táncos meleg szórakozóhely, valamint néhány nagyobb buli - melyek egy-két hetente más-más helyszínen valósulnak meg - továbbá kettő meleg szauna, egy cruising bár és néhány gyógyfürdő képezi a kínálati oldalt. A tematikus vándorló partisorozatok, bulik rámutatnak arra, hogy a korábbi évtizedektől eltérően, manapság szabadabban szórakozhatnak saját köreikben az LMBTQ fiatalok és heteroszexuális barátaik. Szóbeli közlések alapján relevánsnak tartom, hogy a szórakozóhelyeken a külföldi turisták aránya a nyári, főszezoni hónapokban jóval magasabb az év többi részénél. Továbbá megemlítendő, hogy megjelentek egyéb szépségápolási, wellness és egészségügyi szolgáltatók is, akik kifejezetten a melegekre építik a vállalkozásaikat. Mindezek alapján Budapest kiemelkedő az egykori szocialista országok közül, de semmiképp nem rendelkezik olyan határozott meleg turisztikai kínálattal, mint egyes nyugati nagyvárosok, mint például Berlin vagy Madrid.

A szuprastruktúra tekintetében egyre több az olyan szálláshely, amely kifejezetten melegbarát jelzővel is hirdeti magát. Sok időbe telt, mire itthon reagáltak a szállásadók erre a piaci résre. Vidéken mindössze Harkányban, Sopronban és a Balatonhoz közeli Kéthelyen található olyan szálláshely, amely melegbarátként tünteti fel magát, illetve meleg magazinban hirdet. Hirdetéseik alapján a fővárosban jelenleg megközelítóleg egy tucatnyi szállásadóra tekinthetnek melegbarátként az LMBTQ turisták. Az e fajta kommunikáció a célközönség felé meleg magazinokban és az online térben jelenik meg és kutatásom alapjául is ezeket, illetve az interjún kapott információkat használtam. Mivel rejtett populációról van szó, viselkedésük mindennapi, a szállásadók és a vendéglátók esetében előfordulhatnak kellemetlen szituációk. Azonban egyre inkább fel vannak készülve például arra, hogy egy meleg pár is érkezhet a szállodába és foglalhat franciaágyas szobát magának, hiszen a globális városi tömegturizmus következtében már találkoztak LMBTQ turistákkal.

A vendéglátóegységekről, bárokról, éttermekről az online térben juthatnak információhoz az érdeklődők. Továbbá az utóbbi években elindult az úgynevezett „,Biztonságos tér” valamint az „Open for All” kezdeményezés is. Ennek keretében az adott vendéglátó 
egység a bejárati ajtajára ragasztott szivárványszínú matricával jelzi, hogy szívesen látja az LMBTQ vendégeket. Ilyen LMBTQ-barát vendéglátó egységbőll nagyjából 15-20 található, továbbá hét-nyolc bár, illetve kávézó.

\section{Összefoglalás}

Annak ellenére, hogy Magyarországon jogilag nincs engedélyezve az azonos nemúek házassága, nem engedélyezett, hogy két azonos nemú pár gyermeket fogadjon örökbe, társadalmilag nem teljesen elfogadott a homoszexualitás, LMBTQ szempontból a biztonságosabb helyek közé sorolható az ország (Asherfergusson). Ezen megállapítás elsősorban a fóvárosra, annak is a belvárosi részére vonatkozik. Az ország homofóbiához való viszonya európai nemzetközi összehasonlításban jelenleg nem mutat túl pozitív képet.

Világ- és európai viszonylatban Magyarország az LMBTQ jogok szempontjából a kedvezőbb, a társadalmi elfogadottságot nézve viszont a közepesen elfogadó országok közé sorolható (SMiтh Tom W. 2011; KuYPER et al. 2013; TAKÁCs J.-SzALMA I. 2013; Ilga). Elmondhatjuk, hogy jelenleg az állam nem támogatja ezt a fejlesztési irányt a turizmusban, ezzel csak civil szervezetek, egyesületek foglalkoznak.

A jelen kutatás eredménye a megszokottól eltérően új szemszögből, nem az itt élő, hanem az ide utazó, potenciális LMBTQ turistákhoz való hozzáállásba ad betekintést. A primer felmérés eredménye alapján elmondhatjuk, hogy a magyar magasan kvalifikált városi lakosság megengedő az LMBTQ irányú turisztikai fejlesztési irányokkal kapcsolatban. A kutatás további irányaként érdemes lenne a kérdést kiterjeszteni a teljes lakosságra.

A kérdőíves kutatás során feltett három kérdésre adott válaszok települési mintázata azt mutatja, hogy a településnagyság csökkenésével enyhén, de egyenes arányosságban növekedett a negatív vélemények aránya, valamint az egyéni véleménynyilvánítás mértéke. Összességében a kutatás eredménye önmagában pozitív az LMBTQ csoport szempontjából, mert a megkérdezettek közel 2/3-a megengedhetőnek tartja a turizmus ilyen irányú fejlesztését, azonban nyugat-európai összehasonlításban ez a társadalmi hozzáállás magas fokú elutasítást mutat.

Kijelenthetjük, hogy a meleg turizmushoz is kapcsolódó hármas feltételrendszeréből csak a fogadóképesség valósul meg, amely a magyar társadalom részéról megosztó, de inkább a pozitív irányba mutat. A felmérés során a válaszadók rámutattak arra, hogy nemzetközi szinten valószínúleg pozitív benyomást keltene egy melegbarát imázskép az országról, ugyanakkor hazai szinten ez komoly társadalmi és politikai ellenállásba ütközne, ami kulcsfontosságú lehet az itt lévő turista és a hazai LMBTQ közösség szempontjából is.

A magyarországi meleg turizmus kínálata nem bővelkedik a lehetőségekben, ami a kérdőív eredményeivel nincs összefüggésben. Ebből arra a következtetésre jutottam, hogy valószínúleg nem csak a társadalmi elfogadottság az oka annak, hogy Budapesten nem ölt nagy méreteket az LMBTQ turizmus. Ennek oka feltehetóen komplex, történelmi, politikai, társadalmi kérdésekben gyökerezik. A társadalom melegekhez való viszonya a politikai hozzáállással együtt hátráltató tényezőként van jelen a magyarországi LMBTQ turizmus keresletnövekedésben, ily módon a kínálati oldal is korlátozott. Ott, ahol az LMBTQ turizmus virágzik, legtöbb esetben a folyamat politikai támogatottságot is élvez. Tehát ennek hiánya is hozzájárul ahhoz, hogy Budapest, több világvárossal ellentétben nem fó helyszíne az LMBTQ turizmusnak. A fentiek hatása egymást erősítve eddig még nem tette lehetővé az LMBTQ turizmus előre törését Budapesten.

Budapest jelenleg nem értelmezhető nyugati értelemben vett meleg desztinációként és ennek esetleges kialakulása lassú folyamat lenne, amelyre kevés az esély. Ma 
Magyarországon megtűrt formában létezik egy alacsony fokú meleg turizmus, amely véleményem szerint addig a kritikus pontig tartható fenn, ameddig annak láthatósága és jelenléte nem lesz számottevő. Mindaddig, amíg a fővárosi tömegturizmusban képes elvegyülni és annak palástja alatt múködik. Ugyanúgy, ahogy a fóvárosi turistákra, úgy az LMBTQ turistákra is jellemző a nagyfokú belvárosi koncentráltság, aminek következtében Budapesten nem, vagy alig észlelhetô ez a szegmens. A két szélsőséges hozzáállású terület (Kelet- és Nyugat-Európa) közötti földrajzi elhelyezkedésünk mivoltából nehéz megjósolni, hogy a jövőben melyik irányvonal fog erősödni. Mindazonáltal ha figyelembe vesszük, hogy a jelenlegi politikai környezet elhatárolódik az LMBTQ ideológiától és a turizmus ilyen célú fejlesztésétől, valószínűsíthetően Budapest pozíciója az európai LMBTQ turizmus piacán változatlan marad.

Szabó BALÁzs Attila

PTE TTK Földtudományok Doktori Iskola, Pécs

szba@gamma.ttk.pte.hu

\section{IRODALOM}

BAJI P. 2015: Az új gazdaság térnyerése Budapest városközpontjában. - Földrajzi Közlemények 139. 3.pp. 196-212.

BALÁzS F. 2018: A településfejlesztés perspektíváinak vizsgálata marketingföldrajzi szemlélettel. - Földrajzi Közlemények 142.3. pp. 189-200.

BERKI M. 2017: A földrajzi lépték változó értelmezése és a cselekvőhálózat-elmélet. - Földrajzi Közlemények 141.3. pp. 203-215.

Borgos A. 2011: Eltitkolt Évek. - Labrisz Leszbikus Egyesület, Budapest. 352 p.

Brown G.-Browne K. (eds) 2016: The Routledge Research Companion to Geographies of Sex and Sexualities. - London and NY: Routledge. 542 p.

CASTELls M. 1983: Cultural identity, sexual liberation and urban structure: The gay community in San Francisco - In: The City and the Grassroots: A Cross-cultural Theory of Urban Social Movements. University of California Press, Berkeley. pp. 138-170.

Dencső B.-Sik E. 2007: Adalékok az előítéletesség mértékének és okainak megismeréséhez a mai Magyarországon. - Educatio. pp. 50-66.

DusA Á. 2011: A homoszexualitással kapcsolatos előítéletek és sztereotípiák a debreceni egyetemisták körében. - Ifjúsági élethelyzetek-Ifjúságszociológiai tanulmányok. - Debreceni Egyetemi Kiadó, Debrecen. pp. 157-176.

Hanzli P.-Halmai B. G.-Varga P. I.-Seregély Á.-Gyárfás J.-Nagy S. 2015: Meleg férfiak hideg diktatúrák. - Civil Múvek Közmúvelődési Egyesület, Budapest. p. 352.

Hughes Howard L. 1997: Holiday and homosexual identity. - Tourism Management, Vol 18.1, pp. 3-7.

Hughes Howard L. 2006: Pink tourism holidays of gay men and lesbians. - Cabi Publishing, Oxfordshire. 242 p.

J. Carlos Monterrubio 2009: Identity and sex: Concurrent aspects of gay tourism. - Tourismos: An international multidisciplinary journal of tourism. 4. 2. pp. 155-167.

JANKÓ F. 2002: „A hely szelleme, a településimage és településmarketing”.- Tér és Társadalom 16..4.pp.39-62.

J. TAKÁCS-I. SZALMA 2011: Homophobia and same-sex partnership legislation in Europe.-Equality, Diversity and Inclusion: An International Journal 30. 5. pp. 356-378.

J. TAKÁCS-I. SzALMA 2013: How to measure homophobia in an international comparison? - Družboslovne razprave XXIX 73. pp. 11-42.

KÁLMÁn L. 2019: Turizmus és szexualitás. - In: IrimiÁs A. R.-JÁszBERÉNYI M.-Michalkó G.: A turisztikai termékek innovatív fejlesztése. Akadémiai Kiadó, Budapest. pp. 193-203.

KöLlen T.-LÁzÁR Sz. 2012: Gay Tourism in Budapest: An Exploratory Study on Gay Tourists’ Motivational Patterns for Traveling to Budapest. - American Journal of Tourism Management 1. 3. pp. 64-68.

KULCSÁR L. 2020: Földrajz - társadalomtudomány - turizmus: Elméleti és módszertani áttekintés. - Földrajzi Közlemények 144. 1. pp. 2-12.

KuyPer L.-IEdema J.-KeuZenKamp S. (2013): Towards Tolerance: Exploring Changes and Explaining Differences in Attitudes Towards Homosexuality Across Europe (Netherlands Institute for Social Research). Netherlands Institute for Social Research, Den Haag. 80 p. 
Michal P. 2014: Economic, Cultural and Social Factors Influencing the Development of Gay Businesses and Places: Evidence from the European Union. - Moravian Geographical Reports 22. 3. pp. 1-17.

Michal P. 2019: Lessons from the "Periphery": Countering Anglo-Geographic Hegemony over geographies of sexuality and gender. - In. Documents d'Anàlisi Geogràfica 2019, article en premsa pp. 1-23.

Michalkó G.-RÁTZ T. 2013: Rejtett dimenziók a Kárpát-medence turizmusában. - In. FriSNYÁK S. (szerk.): Kárpát-medence: természet, társadalom, gazdaság. - Bocskai István Gimnázium Nyíregyházi Főiskola Turizmus és Földrajztudományi Intézete, Nyíregyháza; Szerencs. pp. 463-476.

Pritchard A.-Morgan N.J.-Sedgley D.-Jenkins A. 1998: Gay Tourism Destinations: Identity, Sponsorship and Degaying. - In: Aitchison C.-JordAn F. (szerk.): Gender, Space and Identity. Leisure Studies Association, Hove. pp. 33-46.

Plummer, K. 1992: Speaking Its Name. Inventing a Lesbian and Gay Studies In Modern Homosexualities. Fragments of Lesbian and Gay Experiences. Routledge, London. 304 p.

Sмiтh, Tom W. 2011: Cross-National Differences in Attitudes towards Homosexuality. University of Chicago, Chicago. p. 33.

TAKÁCS J.-SzALMA I. 2014: A homoszexualitással kapcsolatos társadalmi attitűdök vizsgálata Magyarországon és Romániában - Erdélyi társadalom 12.1. pp. 9-30.

TÍMÁR J. 2007: Gender studies in the gender-blind post-socialist geographies of East-Central Europe - In: Belgeo Revue belge de géographie, Feminist geographies around the world. 23 p.

Tóтн L. 1991: Homoszexuálisok Magyarországon. - Mozgó Világ 3. pp. 110-117.

Tóтн L. 2008: Vélemények a homoszexualitásról. - Esély 3. pp. 55-81.

TÖRő́csıK M. 2002: A „meleg” fogyasztó - célcsoport vagy „,kis színes”. - Marketing \& Menedzsment 36. 4. pp. $57-60$.

TRIHAS N. 2018: Travel motivations, preferences and perceptions of Greek gay men and lesbians - Tourism Today 2018 December. pp. 7-26.

UNWTO 2017: Affiliate Members Global Reports, Volume 15. Second Global Report on LGBT Tourism. World Tourism Organization, Madrid. 112 p.

\section{Internetes források}

Eurobarometer 2019 - Special Eurobarometer 493. Discrimination in the European Union. Brussels: European Commission. https://data.europa.eu/euodp/en/data/dataset/S2251_91_4_493_ENG

BAKó F.-EISINGERnÉ B.B.(2017): A meleg férfiak mindennapjai Magyarországon. SZE.

Győr. https://kgk.sze.hu/images/dokumentumok/kautzkiadvany2017/Bako_Eisingerne_Kautz_2017.pdf (Letöltve: 2020. július 01.)

Magyar LMBT Szövetség: http://www.lmbtszovetseg.hu

Háttér Társaság: http://www.hatter.hu

Pinkbudapest: https://pinkbudapest.com/listing-cat/guided-tours/

Asherfergusson: https://www.asherfergusson.com/lgbtq-travel-safety/

ILGA: https://ilga.org/maps-sexual-orientation-laws

\section{Interjúalanyok}

Erdei Zsolt, Humen Travel Turisztikai Egyesület.

Kristófy Mária, Labrisz Leszbikus Egyesület. 


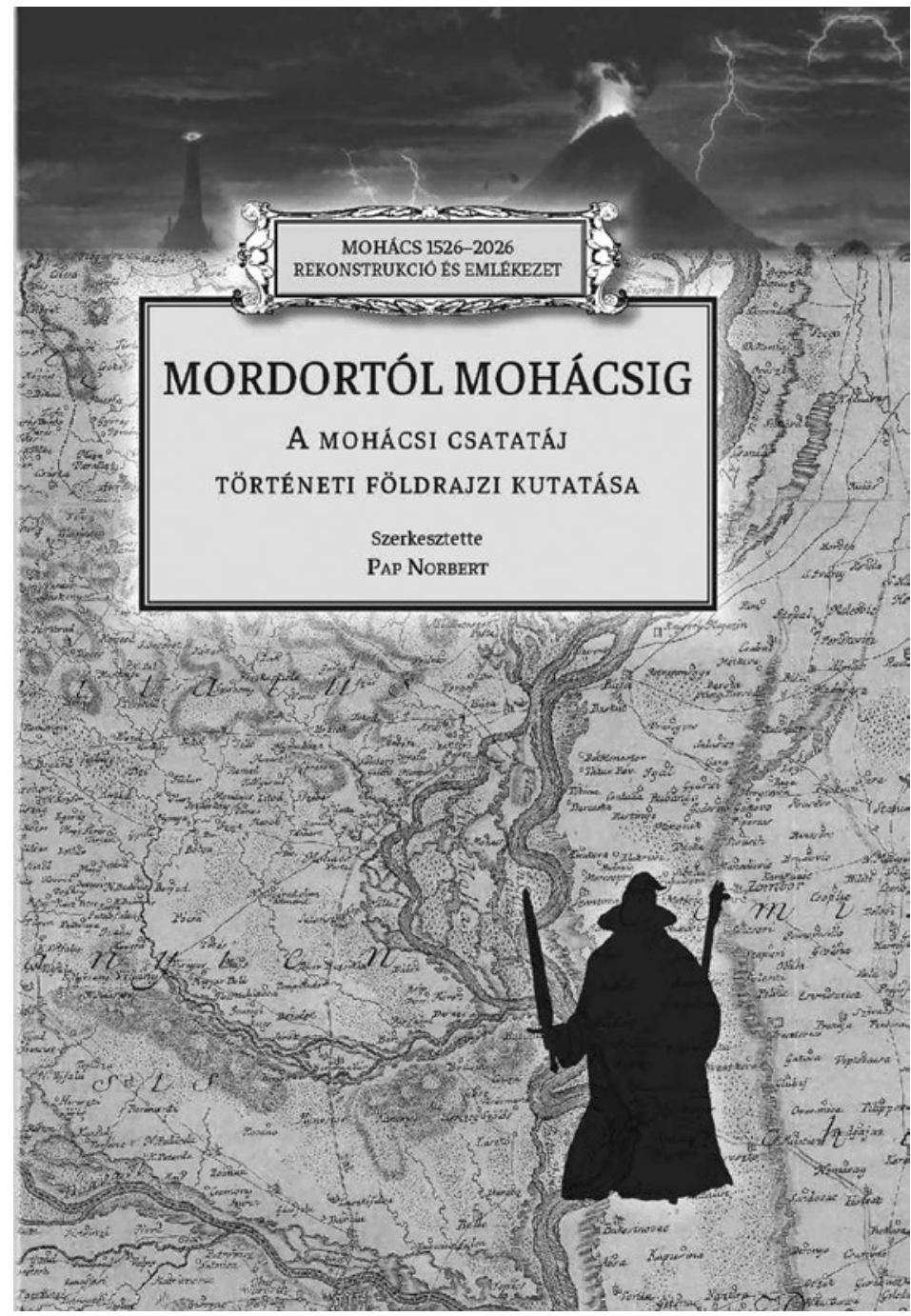

PAP NORBERT (szerk.):

\section{Mordortól Mohácsig - A mohácsi csatatáj történeti földrajzi kutatása}

Bölcsészettudományi Kutatóközpont, Pécs, 2020, 350 p.

A baranyai vízrendszert vizsgáló geomorfológusok, a limest és más korok katonai vonatkozású jelenségeit kutató régészek, a 16-17. századi hódoltsági korral foglalkozó turkológusok, történészek és a military landscapet rekonstruáló történeti földrajzosok ritka együttmúködésére került sor 2017-2020 között, amelynek célje a mohácsi csata földrajzi kereteinek megrajzolása volt. A kötet fôként a katonai táj, de mindenféle emberi használatú táj történeti rekonstrukciójához kínál olyan komplex módszertant, amelyet eddig még senki sem alkalmazott.

További információ: pnorbert@gamma.ttk.pte.hu 


\section{KRÓNIKA}

\section{BACSÁK GYÖRGY (1870-1970) \\ Megemlékezés a kutató születésének 150. és halálának 50. évfordulójára}

BACSÁK GYÖRGY szempontjából egészen rendhagyó év 2020, hiszen ebben az évben ünnepeltük születésének 150. évfordulóját és emlékeztünk meg halálának 50. évfordulójáról.

A neves magyar tudós Pozsonyban született 1870-ben (1. kép). Elemi iskoláit német nyelven végezte Pozsonyban, később jogászdoktori oklevelet szerzett a budapesti Pázmány Péter Tudományegyetemen. A világháborút követően először a Fejér megyei Hörcsökre, majd a Somogy megyei Fonyódra került.

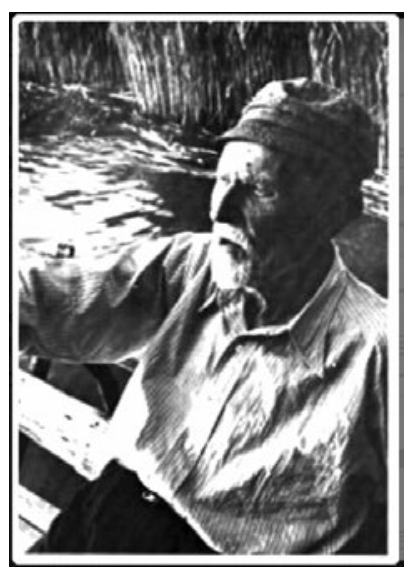

1. kép BACSÁK GYÖRGY Forrás: www.fonyod.hu Photo 1 GYÖRGY BACSÁK Source: www.fonyod.hu

Idejének jó részét a városoktól távol töltötte fonyódi villájában. Mindig korán kelt, későn feküdt és tisztában volt azzal, hogy az elmélyült szellemi tevékenységnek elengedhetetlen kiegészítője az intenzív fizikai munka és a megfelelő sport. Ezt a frissítő kurzust naponta gyakorolta is.

BACSÁK GYÖRGY tárta fel Fonyód város régészeti múltját. Fonyódon, Bélatelepen és a Várhegyen végzett régészeti kutatásokat. Ôskori, római kori, népvándorlás kori és Árpád-kori leleteket gyújtött össze.
Autodidakta módon tette magáévá a csillagászati ismereteket, amelyek széles körú matematikai ismeretein alapultak. Mindezek jelentős szerepet játszottak abban, hogy megismerje és alkalmazza MiLUTin MiLANKOVIĆ elméletét az éghajlatváltozások égi mechanikájáról. BACsÁK GYÖRGY élénk levelezést folytatott a szerb jégkorszak vizsgálójával. Összesen 56 levelet írt neki, míg a szerb tudós 10 levélben válaszolt, amelyek mind fellelhetôk a Magyar Tudományos Akadémia Könyvtárában. A szerb tudóssal folytatott levelezése alapján készítette el kézzel rajzolt deluviális kalendáriumát, amelyet elküldött Milankovićnak. Ezt követően különböző csillagászati lapokban, a Meteorológiai Intézet folyóiratában és a Földtani Intézet lapjában publikálták először a híres MilankovicBacsák elméletet.

A két világháború között Bacsák több előadást is tartott, többek között a Természettudományi Társulat Csillagászati Szakosztályában, különböző meteorológiai társulatoknál, barlangkutatóknál, illetve a híres földrajztudós, LóczY LAJOS kérésére a Földtani Intézetben.

Magyar és német nyelvú tanulmányai is sorra jelentek meg. Sok külföldi tudóssal levelezett, sőt többekkel szenvedélyesen vitázott, hogy elfogadják tudományos állításait.

Első terjedelmesebb írása 72 éves korában jelent meg 1942-ben, a múnek „A skandináv eljegesedés a periglaciális övön" címet adta. 1955-ben látott napvilágot „A pliocén és pleisztocén az égi mechanika megvilágításában" címú munkája. Ezeket a későbbiekben csillagászok, földtan tudósok használták forrásmunkaként! Bacsákhoz világhírû tudósok, csillagászok fordultak kérdésekkel, így nem csoda, hogy balatoni házában kampókra tûzve álltak a levelek.

Sajnálatosan már nagyon későn - 70 évesen publikálta eredményeit az éghajlatváltozásról. A Magyar Tudományos Akadémia felkérésének eleget téve 1954-ben 85 évesen benyújtotta disszertációját a jégkorszakok keletkezésének 
okairól. Dolgozatát olyan sikeresen védte meg, hogy rögtön megkapta az ásványtudományok doktora címet.

A híres Kossuth-díjas professzor, VADÁsz ELEMÉr mondta róla, hogy a „Balaton-parti öregúr a földtörténet egyik legnagyobb tudósa”. Meghívást kapott a római, a madridi, a varsói negyedidőszakot kutató kongresszusokra, ahová csak előadásait küldte el, azokat felolvasták és „az öregurat távolból ünnepelték”.
A híres magyar polihisztor hosszú idôt megélt, talán sport szeretetének, vagy derűs természetének köszönhetően. 100. születésnapja előtt három hónappal 1970. március 4-én hunyt el.

A Magyar Tudományos Akadémia Földtudományi Osztálya 1997-ben emlékülést tartott tiszteletére. BACSÁK GYÖRGYre nagy tisztelettel emlékezik a Magyarhoni Földtani Társulat és a Magyar Földrajzi Társaság. E két szervezet emléktáblát helyezett el a tudós fonyódi házán (2.ábra).

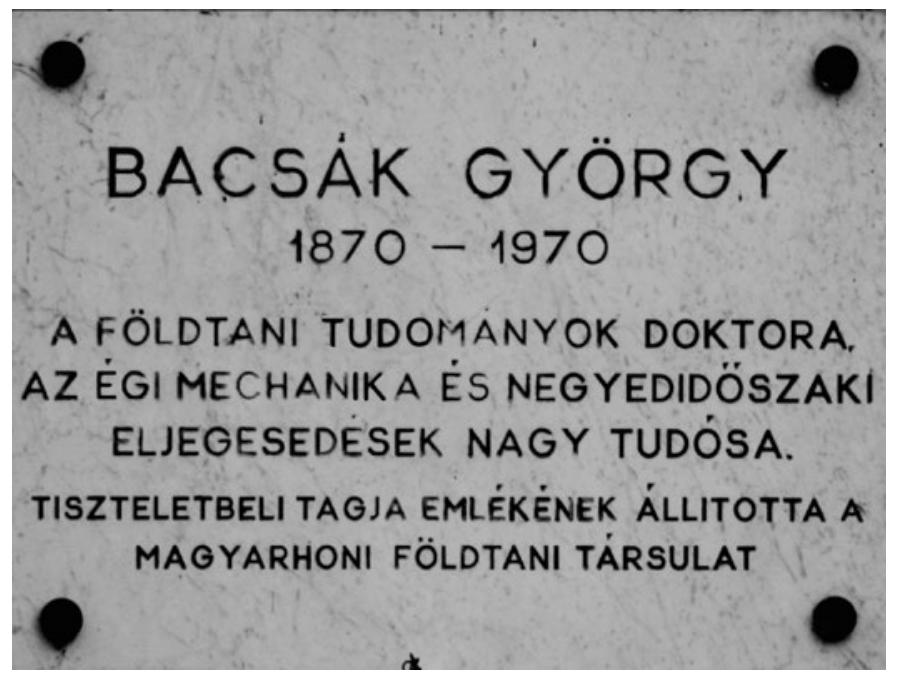

2. kép Bacsák György emléktáblája Fonyódon. Forrás: VARGA IsTVÁN 2019

Photo 2 Bacsák György's plaque in Fonyód. Source: IsTVÁN VARGA 2019

BACSÁK GYÖRGY nem volt széles körben ismert és elismert kutató, pedig munkássága nagyban hozzájárult a tudomány fejlődéséhez, múltunk és jövőnk megismeréséhez. Neve lassan feledésbe merül, pedig Ô volt az az ember, akiról minden magyar példát vehetne!

HÁGEN ANDRÁS

\section{RUDL JóZSEF (1951-2020)}

A Pécsi Tudományegyetem Természettudományi Kara, valamint a Földrajzi és Földtudományi Intézet mély megrendüléssel adja hírül, hogy 2020. december 5-én életének 70. évében elhunyt az intézet egykori tanszékvezető egyetemi docense, Rudl József. Halálával olyan ember távozott körünkből, akinek személye meghatározó jelentőségú volt a kar és az intézet történetében, azokban a fontos és sikeres években, amikor az egykori főiskola egyetemmé lépett elő.

Hiszem, hogy a legtöbb alkotó ember pályafutását meghatározza a hely, ahonnan indult. De valamiért úgy vélem, hogy a geográfusokra ez duplán érvényes, ezért nagyon fontos, hogy Rudl Józsefet elhelyezzük az „idő és a tér keresztjén”, ahogy néhai Tóth József szerette mondani. Rudl József 1951. február 22-én született, születési anyakönyvi kivonatába Komló került be születése helyeként, családja azonban a közeli Mecsekpölöskén élt. A község a Kaszánya-patak és a bányászvárost a világgal összekötő vasúti köldökzsinór mentén fekszik: a települést álmos elhagyatottságából ekkoriban a közeli építkezések zaja verte fel, paraszti közösségét egyre erősebben erodálta az iparosítás, majd az urbanizáció. Ha 30 évvel korábban születik ugyanab- 
ba a „szeretetteljes nagycsaládba”, ahogy maga fogalmazott, talán meg is marad örök életére Pölöske kicsit zárt, de szolidáris és barátságos világában. Így azonban ôt is magával ragadta a társadalmi mobilitás akkoriban dúló fergetege. Kötődése Baranyához, a kis mecseki faluhoz és a középiskoláját adó Komlóhoz soha nem szúnt meg. Mindezeken túl, ha szabad ilyet mondani, „osztályához” sem: a társadalomföldrajzi problémákat világ életében alulról, a földrajzi és társadalmi perifériák felól szemlélte. Mentalitásában, tanári magatartásában a gyámolítás, a rászorulók támogatása mindvégig központi szerepet játszott.

Tehetsége és szorgalma az akkoriban még kifejezetten szúk hazai felsőoktatásba röpítette, annak ellenére, hogy német gyökerei aligha jelentettek számára előnyt az 1960-as években. Mint annyi más első generációs értelmiséginek, számára is a tanári pálya jelentette a továbblépés lehetőségét. Matematika-földrajz szakos oklevelét a Szegedi József Attila Tudományegyetemen szerezte meg. Azon a Gazdasági Földrajzi Tanszéken lett tanársegéd 1975-től, amely az akkor frissen professzorrá kinevezett Krajkó Gyula vezetésével múködött és a gazdasági körzetek hazai kutatásának legfontosabb központjává vált. Szegedi állásában úgyszólván a székhelyét Békéscsabára áttevő Tóth Józsefet váltotta. Első írásai 1978-79-ben még a szegedi Acta Universitatis-ban jelentek meg. Egyetemi doktori disszertációját Csongrád megye tanyavilágának népesség- és településföldrajzi viszonyainak vizsgálatából írta, majd sorra jelentek meg múvei az alföldi tanyarendszer demográfiai és településföldrajzi viszonyairól, a nagyüzemi mezőgazdaság területi hatásairól. Munkáiban elsősorban a településföldrajzi megközelítés, valamint a központosultság és a vonzáskörzetek problémái köszöntek vissza. Életútjában állandó elemként jelentek meg a településhierarchia alacsonyabb szintú központjainak térszervezó funkciói és az ezzel összefüggő problémák vizsgálata.

1981 és 1992 között a JATE adjunktusaként dolgozott. Az egyetemi közéletben szívesen részt vett, megbecsült tagja volt a József Attila Tudományegyetem oktatói gárdájának. A hallgatókkal mindig nagy szenvedéllyel foglalkozott. A tantermi előadásokon és szemináriumokon kívül, terepgyakorlatok és szakmai tanulmányutak sokaságát szervezte és rendszeresen vezetette is ezeket. Szegeden nem csak befogadó szakmai közeget, hanem annál is többet talált, hiszen felesége, Bank Klára nem csak a magánéletben, hanem a munkában is társa lett - végig a szegedi, majd késóbb a pécsi évek alatt is.

A rurális térségek és a központi szerepkörú falvak és kisvárosok kérdésköre mellett állandó elem volt földrajzi érdeklődésében Kelet-Európa, pontosabban az egykori Szovjetunió utódállamai. Kezdetektől fogva publikált orosz nyelven is és ezt kamatoztatva vágott bele egy szovjetorosz kalandba akkor, amikor már a peresztrojka (nyugatias) szelei fújtak a keleti sztyeppék felett. Közelről szemlélhette egy világbirodalom összeomlását, amikor a moszkvai Lomonoszov Egyetem ösztöndíjasaként folytatott kutatásokat kandidátusi értekezéséhez. 1991-ben szerezte meg a címet, a kint töltött időszak tartós öröksége a talán legtöbbször forgatott könyve, „A Szovjetunió utódállamainak földrajza” lett.

A hazatérése után azonban nem a Tiszapartjára, hanem a Mecsek aljára vitte az útja. Feleségével együtt elfogadták Tóth József professzor hívását, aki ezidőtájt vágott bele a pécsi tanszék egyetemi intézetté fejlesztésébe. Rudl József ezzel tulajdonképpen hazatért, legalábbis közelebb került családjához, gyökereihez. 1992-től egyetemi docens volt a JPTE, majd a PTE földrajzi tanszékein, illetve intézetében. Az 1990-es évek végétôl a Regionális Földrajzi Tanszék vezetője volt. A pécsi Földtudományok Doktor Iskola egyik elsố habilitáltja lett 2000ben. Tudományos érdeklődése ekkortájt a falvak demográfiai és társadalomföldrajzi átalakulása felé fordult, több tanulmányt publikált a központi szerepkörök megoszlásáról a rurális térségekben falvak és kisvárosok között. Utolsó jelentősebb munkái a 2000-es években jelentek meg a Tóth József által szerkesztett Világföldrajz kötetben.

Kutatói pályájánál azonban sokkal jelentősebb az a hatás, amelyet egyetemi oktatóként a diákokra és kollégákra gyakorolt. A felsőoktatási karrier egyik nagy igazságtalansága, hogy munkánknak ezen aspektusa nehezebben mérhetô, az e területen kiválót alkotókra kevesebb rivaldafény vetül.

Lelkes és odaadó tanárember volt és maradt egész pályafutása alatt. Pécsi éveinek elején még egy kis létszámú tanszék tagjaként sokféle tárgyat oktatott, később a fokozódó specializáció mellett leginkább a regionális földrajz vált hazai terepévé. Annak ellenére, hogy legjobb indulattal sem lehetett volna nagy világcsavargónak nevezni, szuggesztív előadásaival és mindenkor komplex, az oktatásban tájföldrajzi alapokon álló megközelítései révén képes volt hatásosan láttatni a teret, amelyről tanított. A tanári aszta- 
lon mindig ott hevert elnyúhetetlen spirálfüzete a jegyzeteivel, később ennek szerepét a legendásan híresen hosszú és állandóan bővülő dokumentumfájljai vették át. A vizsgákon alkalmazott kedvenc kérdése az volt, hogy ,pattanjon fel egy biciklire, biciklizzen el, mondjuk Algéria tengerpartjától a Guinea-öbölig, és mondja el, mit lát útközben". Ha pedig a vizsgázó túlzottan kerülgette a témát, akkor gyakran előkerült a „vigyázzon a hantagolyóval” fordulata. Talán ebből is látható, hogy egyik nagy erénye és kitartó népszerűségének oka az volt, hogy képes volt gondolatait közérthetô módon megfogalmazni, aránylag egyszerú, de szilárd ismereteket adva a későbbi földrajztanárok és geográfusok százainak, ezreinek.

Legendásak voltak választható kurzusai, aligha van olyan diplomás kolléga pécsi pályafutásának két évtizedéből, aki ne vette volna fel „A világ nagyvárosai”, vagy a „Szovjetunió utódállamai" tárgyak valamelyikét. Népszerüségének másik forrása közérthetőségén túl következetes hallgatópártisága volt. Tanítványai biztosan számíthattak pártfogására az intézetben és a karon, ahol több bizottság tagjaként végzett fontos munkát. Megszámlálni is nehéz lenne azokat a szakdolgozatokat és diplomamunkákat, ame- lyek az ô felügyeletével készültek el. A doktori iskolában három fiatalabb kutatót segített hozzá témavezetôként a fokozat eléréséhez, de nem csak aktív évei alatt, hanem nyugdíjazása után is állandó és lelkes szereplője maradt a szigorlati és védési eljárásoknak.

Egyetemi docensként, tisztes karriert a háta mögött tudva, a Magyar Földrajzi Társaság Pro Geographia oklevelének birtokosaként vonult nyugállományba 2016-ban. Nem adatott meg neki, hogy hosszú ideig élvezze a nyugdíjas éveket, a jól megszolgált pihenést. Halálával olyan kollégát vesztett el a pécsi és a hazai geográfia, aki pályafutásával végigkísérte és maga is alakította a társadalomföldrajz szemléletváltásának korszakát, kitartó munkájával pedig hozzájárult a pécsi múhely felépítéséhez. Még akkor is, amikor a fiatalabb kollégákkal már nehezebben tartott lépést, sajátos derújével, emberi hangjával, következetes elveivel és legendás, még a szegedi évekből hozott fehér köpenyével az állandóságot, az időtálló értékeket képviselte intézetünkben. Halálával mindannyian szegényebbek lettünk, de legfőképpen persze szerettei és családja, akiknek gyászában, fájdalmában e sorokkal is osztozunk.

PIRISI GÁBOR

\section{Probáld Ferenc 80 éves}

Szép kerek évforduló alkalmából köszönthetjük szakmai mentorunkat, PROBÁLD FERENCet, aki idén áprilisban tölti be életének 80. esztendejét. Probáld tanár úr sokrétú szakmai pályafutást tudhat maga mögött, amiról több interjút is olvashattunk az elmúlt évtizedben. A hazai viszonylatban annak idején úttörőnek számító városklimatológiai és a klímaváltozáshoz kötődő kutatásairól JANKó FERENC (2016), míg tudománytörténeti kérdésekhez kapcsolódóan GYŐRI RÓBERT (2011) beszélgetett vele szakmai életútjáról. Ezeken túl az ünnepelt a maga által szerkesztett „Válogatott tanulmányok a földrajzról” címú kötetben foglalta csokorba azokat a tudományelméleti kérdéseket, amelyek az elmúlt három évtizedben foglalkoztatták (PROBÁLD F. 2016). Sokrétú szakmai munkássága kapcsán PROBÁLD FERENCről, mint a regionális földrajz hazai kiemelkedő múvelőjéről és mint regionális földrajzi ismeretterjesztőről szeretnénk írni.

Az 1960-as évek közepén, amikor PROBÁLD FERENC karrierje elindult először városklíma-kutatóként az ELTE Természetföldrajzi Tanszékén, majd pár évvel később a Regionális Földrajzi Tanszéken, a magyarországi szocialista rendszer már a konszolidáció időszakát élte. Az 1950-es évekhez képest ez egy viszonylag szabadabb akadémiai légkört és szélesebb tudományos lehetôségeket jelentett. PROBÁLD FERENC szakmai látásmódját és tudományos érdek lődésének alakulását nagyban befolyásolta, hogy Nyugatra is eljutott tanulmányutak és ösztöndíjak segítségével. Az 1968-as három hónapos finnországi utat az 1970-es évek elején az USA-ban töltött egy év követte Ford ösztöndíjjal. A kor viszonyainak megfelelően a kiutazást számos adminisztratív akadály nehezítette, ráadásul az USA-ból csak levélben, illetve nagy ritkán telefonon tudta otthon maradt családjával tartani a kapcsolatot. PROBÁLD FERENC megfordult a kor meghatározó amerikai földrajzi múhelyeiben és a gazdag szakmai tapasztalatok, illetve több nyugati kiadvány mellett Peter HagGetT akkor megjelent Modern Geográfiájával tért vissza a vasfüggöny mögé. Az 1980-as években vendégoktatató volt a nyugat-németországi Heidel- 
bergben, majd az 1990-es években az újabb heidelbergi és freiburgi tanulmányutak mellett Hollandiába és az Egyesült Királyságba is eljutott vendégkutatóként.

PROBÁLD FERENC 1967-tôl egészen 2004-es nyugdíjba vonulásáig az ELTE Regionális Földrajzi Tanszékének oktatója, emellett 1990 és 1994 között tanszékvezetôje volt. A Tanszék akkoriban egyetlen hazai intézményként fó profiljában foglalkozott a külországok földrajzával, így ProBÁLD FERENC első regionális földrajzi publikációi is ekkor jelentek meg, többek között az Európai Unió elódjéről, a Közös Piacról (Probáld F. 1967). Két évre rá a Szovjetunió népesedési folyamatairól írt egy tanulmányt újszerû megközelítésben (PROBÁLD F. 1969). Hazánkban elsőként alkalmazta e dolgozatában a kartogram (izodemográfiai) térképet, a topologikus térképek egyik fajtáját a Szovjetunió európai és ázsiai fele közötti népességkülönbség látványos érzékeltetésére. Korát jócskán megelőzve foglalkozott a Budapesten belüli népesség-szegregációval is (PROBÁLD F. 1975). Emellett figyelme az 1970-es évektől a tanszéki profilba illeszkedve egyre inkább a regionális földrajzi tankönyvírás felé fordult. Ennek mellékvizén több regionális földrajzi vázlatot is publikált a Földrajzi Közleményekben (PROBÁLD F. 1979, 1980, 1988). Az 1980-as évek második felében a világgazdasági regionális földrajzi kérdéseivel foglalkozott több tudományos publikációban (PROBÁLD F. 1984, 1987, 1990), ami az akadémiai doktori értekezésének (DSc, 1991) is témája volt.

Hazánkban az 1965 után született generációk mind találkoztak PROBÁLD FERENC nevével a gimnáziumi földrajzkönyveken, amelyek a földrajztudományról alkotott általános képet is alapvetően formálták Magyarországon. A számos kiadást megélt, általa jegyzett „Földrajz” második osztályos tankönyv (1979) borítóján a Fuji előtt elszáguldó sinkanzen látványa két évtizeden át igézte meg fiatal gimnazisták tekintetét távoli tájakról és országokról.

Sokunkat az általa írt, külországokat és régiókat bemutató tankönyvek tereltek a felsőfokú geográfiai tanulmányok felé, ahol egyetemi regionális földrajzi jegyzetek, tankönyvek borítóin nem csak újra találkozhattunk a nevével, de immár elôadásait is hallgathattunk a világ államainak regionális sokszínúségéről. Megtiszteltetés volt számunkra, amikor szakmai mentorunk mellett idővel mi is szerzői, társszerkesztôi lehettünk az Európáról (PROBÁLD F. 2000, Probáld F.-SZABó P. 2007), Amerikáról
(Probáld F. 2005), illetve Ázsiáról (ProbÁld F.-HoRVÁtH G.-SzABó P. 2008) szóló regionális földrajzi egyetemi tankönyveknek. Az ELTE Eötvös Kiadó ezen egyetemi tankönyvsorozatának előképeként már az 1980-as évektől jelentek meg a Tankönyvkiadó Vállalat gondozásában több kiadást megélt, kiadói nívódíjjal kitüntetett regionális gazdaságföldrajzi kötetek, amelyekben PROBÁLD FERENC szívéhez Észak-Amerika, Kína és Tajvan, illetve a Közel-Kelet állt a legközelebb. Ahogy előadásaiban, úgy írásaiban is túllépett a száraz, leíró, adathalmozó jellegen és a gondosan kiválogatott tények megfelelő logikai keretet, stílusos leírást és informatív ábrákat kaptak. Habár napjainkban sokan az internetrôl tájékozódnak, ha egy-egy országról, régióról, városról gyűjitenek információt, ám ezek a leírások magyarázatok, ok-okozati viszonyok és érdemi szakmai kontroll nélküliek, szemben Probáld tanár úr igényesen megkomponált, a földrajzi összefüggésekre rávilágító regionális földrajzi munkáival.

A Regionális Földrajzi Tanszéken múködő, SÁrfalvi Béla, Szegedi Nándor és a most 80 esztendős PROBÁLD FERENC nevével fémjelzett múhely a tankönyvek mellett gondosan kimunkált, igényesen illusztrált regionális földrajzi ismeretterjesztő kötetekkel és útikönyvekkel látta el a szélesebb olvasóközönséget. Mindezt egy olyan korban, amikor nemhogy internet, de még csak színes tévé sem volt nagyon és a magyar lakosság jelentôs részének nem volt lehetôsége távoli tájakra eljutni. Így komoly érdeklődés volt e képekkel illusztrált kiadványok, valamint a Természet Világában megjelenő ismeretterjesztő cikkek és a munkahelyi kollektívák számára tartott vetített képes előadások iránt. A Móra Kiadó Képes Földrajz sorozatának első tagját is Probáld FERENC jegyezte, amely kötet Észak-Amerikáról szólt (PROBÁLD F. 1979c). Emellett az ünnepelt a méltán híres Panoráma útikönyv-sorozatból is kivette a részét, többek között a Törökországot, Dániát, Szíriát és Németországot tárgyaló kötetekben.

PROBÁLD FERENC életének 80. esztendejében is rendkívül aktív szakmailag. Professor emeritusként részt vesz a Tanszék szakmai munkájában regionális társadalomföldrajzi munkák opponálásával és doktori bizottságok tagjaként. A koronavírus-pandémia idején kényszerúen otthon töltött napjaiban fáradhatatlanul lektorálja az új Magyar Nemzeti Atlasz angol és magyar nyelvú köteteit. Emellett mindig örömmel olvas el és véleményez minden olyan dolgozatot, ame- 
lyet tudományos publikációnak szánnak tanítványai. A tanít ványok és a kollégák ezért is várják, hogy a vírusveszély elmúltával újra személyesen találkozhassanak és diskurálhassanak vele szakmai kérdésekről, meghallgatva sok évtizedes tudományos tapasztalatait.
Kedves Tanár úr, ezúton kívánunk az egész szakma nevében boldog születésnapot és még nagyon sok, jó hangulatban és egészségben eltöltött aktív évet!

KaRÁCSONYI DÁVID - SZABÓ PÁL 


\section{Szerzőink figyelmébe!}

Kérjük Szerzőinket, hogy megjelentetésre szánt cikkük, tanulmányuk elkészítésekor kövessék a Földrajzi Közlemények tanulmányainak formai felépítését és az alábbi szempontokat vegyék figyelembe!

\section{Szöveg}

A tanulmányt a szerző az elektronikus beküldő felületen keresztül töltheti fel a Földrajzi Közlemények rendszerébe. A felület elérhető a Magyar Földrajzi Társaság honlapján, a Földrajzi Közlemények oldalán. Kérjük Szerzőinket, hogy tanulmányukat a formai követelményeknek megfelelően formázva küldjék be! Az anyag terjedelme legfeljebb 40 ezer karakter lehet szóközökkel. A tanulmányhoz 10-15 soros összefoglalót és 3-5 kulcsszót mellékeljenek angol nyelven! A szövegben lábjegyzetet csak kivételes esetben alkalmazzanak, végjegyzetet ne használjanak! A tanulmányokban 3 fokozatú címrendszer használható (fejezetcím, elsőrendű alcím, másodrendú alcím).

\section{Szakirodalmi hivatkozások}

A hivatkozás formája: A szerzó neve (keresztnevének rövidítésével) és a megjelenés éve. A szövegkörnyezettől függően: TóTH Z. (2018) vagy (TóTH Z. 2018). Külföldi szerző publikációjára történő hivatkozáskor a név két tagja közé vessző kerül: (HARRISON, M. 2017).

Többszerzős hivatkozás esetén a nevek közé nagykötőjel kerül: (HoRváth S.-SOLYMOS G. 2016). Ha a hivatkozott munkának háromnál több szerzője van, csak az elsőnek a neve szerepeljen: (KovÁcs B. et al. 2013). Ha adott szerzőnek egy évben több publikációjára történik hivatkozás, akkor az évszámhoz a, b stb. írandó: (То́тн Z. 2012a).

Felsorolásszerú hivatkozások esetén az egyes - időrendbe és nem ábécé-sorrendbe rendezett tételeket pontosvessző választja el: (NÉMETH P. 2008; HORVÁTH V. 2006).

\section{Irodalomjegyzék}

$\mathrm{Az}$ értekezés végén a felhasznált munkák jegyzéke szerzők szerint ábécé-sorrendben, ezen belül időrendben legyen! Az Irodalomjegyzékben a tanulmányban hivatkozott minden mú könyvészeti adatának szerepelnie kell.

\section{A különbözó jellegú kiadványok mintája}

Könyv: MENDÖL T. 1963: Általános településföldrajz. - Akadémiai Kiadó, Budapest. 567 p.

Könyvfejezet: SzÉKELY A. 1998: A periglaciális felszínformálás. - In. BoRsY Z. (szerk.): Általános természetföldrajz. Nemzeti Tankönyvkiadó, Budapest. pp. 356-421.

Folyóirat: BeLUSZKY P. 2005: A mezôvárosok és az ,alföldi út”. - Földrajzi Közlemények 53. 1-2. pp. 31-46.

Krolopp E.-SÜmegi P.-Kuti L.-HerteLENDI E.-KordOS L. 1995: Szeged-Öthalom környéki löszképződmények keletkezésének paleoökológiai rekonstrukciója. - Földtani Közlemények 125. 4. pp. 309-361.

\section{Ábrák, fényképek, táblázatok}

A tanulmányhoz tartozó ábrákat, fényképeket (a törzsszövegben a források pontos megjelölésével, angol és magyar nyelvú aláírásokkal) külön fájlokban kérjük feltölteni! Wordbe beszúrt illusztrációt nem fogadunk el! A szövegben feltétlenül szerepeljen rájuk utalás, hivatkozás.

\section{Ábrák}

Az ábrákat eps vagy ai, esetleg egyéb olyan vektorgrafikus formátumban kérjük, amelyet az Adobe Illustrator szoftver kezelni, importálni képes. Vegyék figyelembe, hogy a jpg és tif formátumban beküldött ábrák nehezen szerkeszthetők. Az ábrákon csak a legszükségesebb felírások (földrajzi nevek, méretek, a jelmagyarázat sorszámai, betújelzései stb.) szerepeljenek, minden egyéb információ (cím, a sorszámok, betűjelzések magyarázata stb.) az ábraaláírásba kerül. Az ábrákban szereplő felírásoknál kérjük egységesen a Times betútípust, valamint 8-10 pontos betúnagyságot alkalmazni nyomdai méret esetén. Az ábrákon az alkalmazott koordinátarendszerek stílusa, beosztásai, mértékegységei egységesek legyenek! Az ábrák fontjait görbékké konvertálhatja a szerző, megelőzve így az utólagos szerkesztést. A fekvő ábra szélessé- 
ge 70-125 mm között változhat, az álló ábrák maximális magassága $182 \mathrm{~mm}$ lehet. A szerző úgy segítheti legjobban szerkesztôségünk munkáját, ha a fenti kérések figyelembevételével úgy és olyan méretben küldi be az ábrákat, ahogyan azokat nyomtatásban látni szeretné.

\section{Fényképek}

A fényképeket kérjük tif vagy jpg formátumban beküldeni! A fotókat javasoljuk a felhasználni kívánt nyomdai méretben 300 dpi-vel szkennelni. Kisebb méretû fényképet, diát nagyobb felbontással kell szkennelni.

\section{Táblázatok}

A táblázatokat Word (doc), Excel (xls), vagy eps formátumban várjuk szerzőinktől, a jpg és tif formátumot szíveskedjenek mellőzni! Keretezés és rácsozás felesleges: elválasztó vonalak csak a fejlécben, illetve az oszlopok között szükségesek.

Felhívjuk Szerzőink figyelmét, hogy a tanulmányok beküldési lehetősége e-mailben és egyéb adathordozón megszúnt. A tanulmányok beküldéséhez a folyóirat elektronikus felületét vegyék igénybe:

http://ojs3.mtak.hu/index.php/fk/login 


\section{MAGYAR FÖLDRAJZI TÁRSASÁG \\ ALAPÍTVA: 1872}

\section{Tisztikar}

Elnök: CSORBA PÉTER egyetemi tanár

Tiszteletbeli elnök: PAPP-VÁRY ÁRPÁD ny. egyetemi tanár

Alelnökök: MichALKÓ GÁBOR tudományos tanácsadó, egyetemi tanár

SZILASSI PÉTER egyetemi docens

Fơtitkár: DÁVID LóRÁNT DÉNES egyetemi tanár

Titkár: JENEY LÁSZLó egyetemi docens

Felügyelóbizottság: KERESZTY PÉTER, NEMERKÉNYI ZsOMbOR, SZABÓ GYÖRGY

\section{Választmány}

AUBERT ANTAL szakosztályelnök, intézetigazgató

BERNEK ÁGNES szakosztályelnök, főiskolai tanár

BuJDOSÓ ZoLTÁN főiskolai tanár

DÁVID LÓRÁNT DÉNES osztályelnök, egyetemi tanár

DOROGI LÁSZLÓNÉ középiskolai tanár

EgEDY TAMÁs tudományos főmunkatárs, egyetemi docens

FARSANG ANDREA egyetemi docens

FRISNYÁK SÁNDOR osztályelnök, ny. egyetemi tanár

GERHARDTNÉ RUdLI ILONA ny. középiskolai tanár

GöNCZI SÁNDOR osztályelnök, főiskolai docens

GRUBER LÁSZLÓ középiskolai tanár

GYENIZSE PÉTER egyetemi docens

GYŐRI RÓBERT tszv. egyetemi docens

GYURICZA LÁSZLó osztályelnök, egyetemi docens

GyURIS FERENC egyetemi adjunktus

HeVesi ATTILA osztályelnök, ny. egyetemi tanár

HUSZTI ZsOLT osztályelnök, intézetigazgató

KARANCSI ZOLTÁn tszv. egyetemi docens

KARÁTSON DÁVID szakosztályelnök, tszv. egyetemi tanár

KIs JÁNOS középiskolai tanár

KIss EDIT Éva tudományos tanácsadó, egyetemi tanár

KLINGHAMMER ISTVÁN szakosztályelnök, akadémikus

KocSIS KÁROLY akadémikus, egyetemi tanár

KOPEK ANNAMÁRIA osztályelnök, osztályvezető
KOROMPAi ATTILA ny. egyetemi docens

KovÁCs ZolTÁN akadémikus, egyetemi tanár

KozMa GÁBOR tszv. egyetemi docens

KUBASSEK JÁNOS múzeumigazgató

KUNOS GÁBOR szakosztályelnök, villamosmérnök

LENNER TIBOR osztályelnök, tszv. egyetemi docens

LERNER JÁNOS OsZtályelnök

M. CSÁSZÁR ZsUZSANNA osztályelnök, egyetemi docens

MÁJAI CsABA osztályelnök

MAKÁDI MARIANN szakosztályelnök, főiskolai docens

MUCSI LÁSZLÓ osztályelnök, egyetemi docens

NAGY BaLÁzs egyetemi docens

PAP NORBERT osztályelnök, tszv. egyetemi tanár

PÁL VIKTOR egyetemi docens

RADICS ZsOLT egyetemi adjunktus

SIMON GYÖRGY középiskolai tanár

SISKÁNÉ SZILASI BEÁTA egyetemi docens

SuBA JÁNOS szakosztályelnök, térképész

SZÖRÉNYINÉ KUKORELLI IRÉN osztályelnök, tudományos tanácsadó, egyetemi tanár

SZŐLLŐSY LÁSZLÓ középiskolai tanár

TEPERICS KÁROLY osztályelnök, egyetemi adjunktus

TIMÁR JUDIT osztályelnök, tudományos főmunkatárs

TÓTH ANTAL osztályelnök, főiskolai docens

TÖMPE LÁszLó szakosztályelnök, középiskolai tanár

TRÓCSÁNYI ANDRÁs szakosztályelnök, tszv. egyetemi docens

VIZI IsTVÁN osztályelnök

\section{A Közgyúlés által megválasztott tiszteleti tagok a Magyar Földrajzi Társaság Választmányának örökös tagjai.}




\section{TARTALOM / CONTENTS}

\section{Értekezések / Studies}

SzIRMAi VIKTóRIA: Nagyvárosok a COVID-19 vírusjárvány idején / Metropolises at the time of the COVID-19 pandemic

REMÉNYi PÉTER-CSAPÓ DÁNIEl GÁBOR: A szállítási infrastruktúra fejlesztése és a geopolitika összefüggései a Nyugat-Balkánon / Relationship between the development of transport infrastructure and geopolitics in the Western Balkans

Koudela PÁL: Dzsentrifikáció Szöul belvárosában - Cshonggjecshon / Gentrification in Seoul's downtown - Cheonggyecheon

SoHA TAMÁs -NÉMETH IZABELLA-MunKÁCSY BÉLA: Magyarország térinformatikai alapú gyorsforgalmi átjárhatósági vizsgálata az elektromobilitás szempontjából - helyzetkép és fejlesztési lehetőségek / GIS-based connectivity analysis from the perspective of e-mobility on Hungarian motorways - current status and possible developements

Szabó BALÁzs ATTILA: Az LMBTQ turizmus kínálati oldalának vizsgálata a magyarországi egyetemisták körében / Research on the supply side of LGBTQ tourism among Hungarian university students

\section{Krónika / Chronicle}

Bacsák György (1870-1970) - Megemlékezés a kutató születésének 150. és halálának

50. évfordulójára - HÁGEN ANDRÁs

Rudl József (1951-2020) - PIRISI GÁBOR

Probáld Ferenc 80 éves - KarÁCSONYI DÁvid-SZABó PÁL

Kiadja a MAGYAR FÖLDRAJZI TÁRSASÁG

A Nemzeti Kulturális Alap és a Magyar Tudományos Akadémia támogatásával

A kiadásért felel: Dávid Lóránt Dénes

Tördelés és nyomdai előkészítés: Bonex Press Kft.

Borítóterv: Liszi János

Nyomdai kivitelezés: Heiling Media Kiadó Kft.

Telefon: (06-1) 231-4040

Készült 300 példányban

HU ISSN 0015-5411 